INSTITUTO DE PESQUISAS ENERGÉTICAS E NUCLEARES

AUTARQUIA ASSOCIADA Á UNIVERSIDADE DE SÃOPAULO

\title{
INIBIÇÃO DO CRESCIMENTO DA MICROFLORA ORAL POR VENENOS DE SERPENTES
}

Rodrigo Crespo Mosca

Dissertação apresentada como parte dos requisitos para obtenção do Grau de Mestre em Ciências na Área de Tecnologia Nuclear - Aplicações

Orientadora: Prof . Dr ${ }^{2}$. Nanci do Nascimento

São Paulo

2008 


\section{Dedico este trabalho a minha família:}

A minha Mãe Dinian, fonte inspiradora, incentivadora e sempre presente em toda minha vida. Nos momentos difíceis me deu força para continuar e não desistir. Educou-me com muito carinho, compreensão e amor. Obrigado Mãe.

A minha Irmã Guta, que me ajuda em tudo, se esforça para me deixar tranqüilo, me ensina a viver. Desde criança é minha companheira, amiga e também "mãe”. Obrigado Guta.

Ao meu Pai Oswaldo, que proporcionou este momento, pois me "obrigou" a estudar, mostrando o quanto poderia ser importante, não medindo esforços para que isto fosse possível. Obrigado Pai.

Ao meu Avô Tonico, lúcido, inteligente e perseverante. Obrigado Vô.

$\mathrm{Na}$ vida existem certos momentos, que se sente muito a falta de alguém, a ponto de querer tirá-lo de seus sonhos e reviver momentos inesquecíveis... A você meu amigo, meu irmão, Skinner (in memorian) saudades... E a você Pingo (in memorian), o membro mais recente da nossa família que trouxe tanta alegria a todos, saudades...

A minha namorada Gisele, uma mulher especial, carinhosa e companheira. Concordo que me agüentar não é fácil...

Mesmo com todos os percalços, consegue me alegrar e ainda ajudar. Obrigado por estar comigo e por me compreender.

Ao meu cunhado André, um homem generoso e amigo. Hoje parte de nossa família. Obrigado por tudo que fez por mim.

Sei que sem vocês eu não seria absolutamente nada. Não conseguiria descrever em tão pouco espaço tudo o que fizeram por mim, por isso deixo aqui uma mensagem: AMO TODOS VOCÊS. 


\section{Agradecimentos especiais:}

A minha orientadora e também amiga, Prof ${ }^{\mathrm{a}}$. Nanci do Nascimento, que me ajudou a elaborar esta dissertação com muito esforço para que tudo fosse possível. Quando parecia não haver mais solução, recorria a sua imensa sabedoria, ser humano incrível;

A Prof ${ }^{a}$. Priscilla Longo, por fazer com que este trabalho fosse realizado. Cedeu-me as bactérias, ensinou-me como proceder e ainda arriscou-se por alguém desconhecido, somente pelo simples fato de acreditar. Muitíssimo obrigado.

Ao meu "co-orientador" e grande amigo Murilo, que me ensinou técnicas laboratoriais, me deu conselhos, elaborou idéias, se preocupou com meus resultados e ainda achou tempo para ser meu amigo.

A grande amiga Jana, parte presente nesta dissertação, sempre esteve preocupada comigo e com meu trabalho, me ajudou em tudo no IPEN. Sem você não teria conseguido chegar até aqui.

Ao amigo Junior, que deixou sua tese de lado para me ajudar nos dias contados que pude comparecer ao IPEN, me ensinando a usar as técnicas corretas e os aparelhos devidos;

A Fê, minha amiga, que me ensinou como trabalhar com bactérias e me ajudou para que pudesse dar certo com os experimentos.

A Renata que me ajudou com muita dedicação;

A Rosa que teve paciência de me ajudar todas as vezes que precisei;

Ao Prof. Patrick que me ajudou a elaborar minha pesquisa com enorme conhecimento; 
Ao Jonnhy que sempre alegre me ajudou em tudo com sua boa-vontade e experiência, obrigado amigo;

A Miriam a quem pude recorrer para elaboração dos resultados do Prisma;

Ao Prof. Heitor que abdicou do seu tempo livre no fim de semana somente para analisar meus dados e mostrar o que poderia ser útil. $E$ com seu ensinamento ajudando a me preparar para a apresentação;

A Profa ${ }^{a}$ Mônica por sempre me incentivar e servir de inspiração para que pudesse continuar, mesmo com as grandes dificuldades que enfrentei.

Aos meus amigos Dani, Priscilla, Tiago, Alberto, Karina, Kelly, Jean, Bruno, Natalia, Kiki, Karina e a todos os funcionários do IPEN por me fazerem acreditar que poderia dar certo e me ajudarem.

Obrigado aos meus novos amigos. 


\section{INIBIÇÃO DO CRESCIMENTO DA MICROFLORA ORAL POR VENENOS DE SERPENTES}

Rodrigo Crespo Mosca

\section{RESUMO}

A saúde bucal, na maioria dos municípios brasileiros, constitui ainda um grande desafio aos princípios do Sistema Único de Saúde, principalmente no que se refere à universalização, à eqüidade do atendimento e alto custo envolvido na terapia restauradora.

A procura pela descoberta de novos compostos metabólicos com atividade antibacteriana para a prevenção de doenças bucais e talvez com menores impactos a saúde e financeiros, seria muito importante para obtenção de um meio efetivo de controle da formação de um biofilme patogênico e da cárie dental.

O objetivo deste trabalho é estudar a viabilidade biotecnológica do uso de venenos nativos de diferentes serpentes quanto à capacidade de inibir o crescimento de Streptococcus mutans, principal agente envolvido na cárie dental.

Nossos resultados mostraram que os venenos das serpentes Bothrops moojeni e Bothrops jararacussu inibiram o crescimento de Streptococcus mutans e o componente responsável pela inibição parece ser a peróxido de hidrogênio.

Apesar de ainda não totalmente conclusivos, os ensaios já realizados, permitem afirmar que venenos de serpentes são ferramentas importantes na inibição do crescimento de patógenos, especificamente daqueles envolvidos nas doenças cariogênicas. 


\title{
GROWTH INHIBITION OF ORAL MICROFLORA BY SNAKE VENOMS
}

Rodrigo Crespo Mosca

\begin{abstract}
The oral health at the most of Brazilian municipalities is still a big challenge to the principles of the Brazilian Health Unique System (SUS), particularly with regard to the globalization, the equity of care and high cost involved in restorative therapy.

The demand for discovery of new natural products with antibacterial activity in order to prevent dental diseases and perhaps with fewer health and financial impacts, would be very important to achieve an effective means to control the formation of a pathogenic biofilm and dental caries.

The objective of this work is to study the feasibility of the use of different snakes crude venom in inhibiting the growth of Streptococcus mutans, the principal agent involved in dental caries.

Our results showed that Bothrops moojeni and Bothrops jararacussu venoms were able to inhibit the growth of Streptococcus mutans and the component responsible for that inhibition appears to be the hydrogen peroxide.

Though still not fully conclusive, the tests already carried out, show that snake venoms are important tools to inhibit the growth of pathogens, specifically those involved in caries diseases.
\end{abstract}




\section{SUMÁRIO}

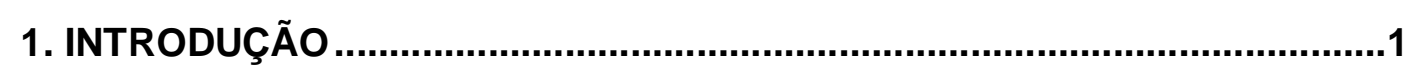

1.1. EPIDEMIOLOGIA DA CÁRIE DENTAL NO BRASIL E NO MUNDO ...................1

1.2. A CÁRIE DENTAL, A MICROBIOTA ORAL E OS Streptococcus mutans .............5

1.3. O SURGIMENTO, PROPAGAÇÃO E TRANSMISSÃO DOS Streptococcus

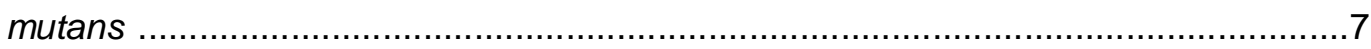

1.4. A PROBLEMÁTICA DA CÁRIE E A SAÚDE GERAL ....................................

1.5. VENENOS DE SERPENTE ...............................................................

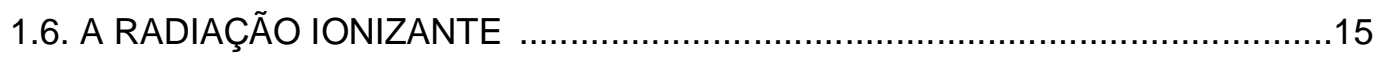

2. OBJETIVOS..........................................................................................18

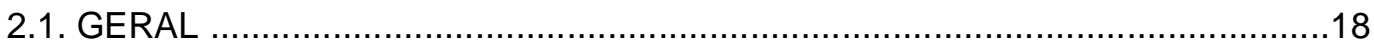

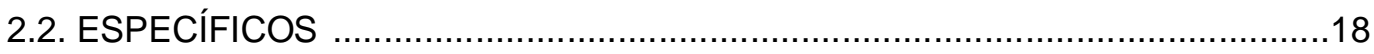

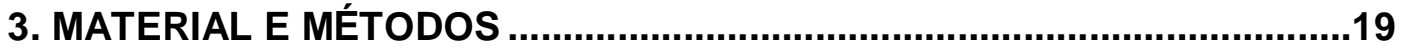

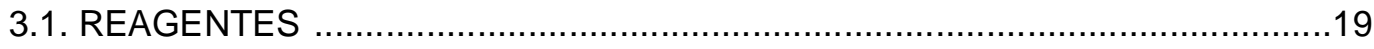

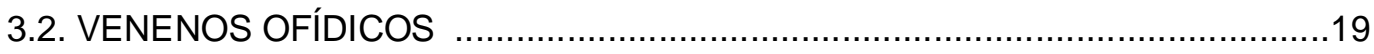

3.3. FONTE DE RADIAÇÃO E IRRADIAÇÃO DE VENENOS ..............................20

3.4. BACTÉRIAS E CURVA DE CRESCIMENTO BACTERIANO .........................20

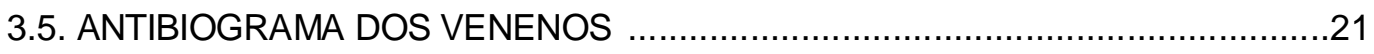

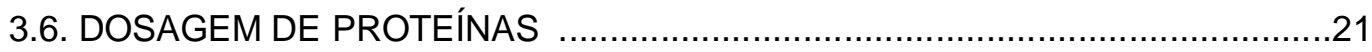

3.7. DETERMINAÇÃO DA CONCENTRAÇÃO INIBITÓRIA MÍNIMA (MIC) DOS VENENOS COM CAPACIDADE DE INIBIR O CRECIMENTO DE Streptococcus mutans

3.8. FRACIONAMENTO POR CROMATOGRAFIA DE EXCLUSÃO MOLECULAR DOS VENENOS EFETIVOS 
3.9. ANTIBIOGRAMA DAS FRAÇÕES DOS VENENOS DE Bothrops moojeni E Bothrops jararacussu

3.10. DETERMINAÇÃO DAS (MIC) DAS FRAÇÕES DOS VENENOS DE Bothrops moojeni E Bothrops jararacussu COM CAPACIDADE DE INIBIR O CRESCIMENT

\section{RESULTADOS}

4.1. BACTÉRIAS E CURVA DE CRESCIMENTO BACTERIANO .26

4.2. ANTIBIOGRAMA DOS VENENOS .26

4.3. DETERMINAÇÃO DA PROPORÇÃO DE INIBIÇÃO DE CRESCIMENTO BACTERIANO DOS VENENOS COM CAPACIDADE DE INIBIR O CRESCIMENTO DE S. mutans .28

4.4. CROMATOGRAFIA POR FPLC 29

4.5. ANTIBIOGRAMA DAS FRAÇÕES DOS VENENOS DE Bothrops moojeni E Bothrops jararacussu

4.6. DETERMINAÇÃO DA PROPORÇÃO DE INIBIÇÃO DE CRESCIMENTO BACTERIANO DAS FRAÇÕES EFETIVAS DOS VENENOS DE Bothrops moojeni E Bothrops jararacussu .36

5. DISCUSSÃO .40

6. CONCLUSÕES 50

7. REFERÊNCIAS BIBLIOGRÁFICAS .51

8. ANEXOS 65 


\section{INTRODUÇÃO}

A busca por uma nova droga capaz de eliminar ou amenizar os males causados por patógenos, tem sido incessante nas ultimas décadas. O uso de substâncias encontradas na natureza tem como objetivo reduzir os efeitos adversos freqüentemente causados por produtos industrializados, bem como diminuir o impacto econômico causado com o desenvolvimento de novas drogas sintéticas. Dentro deste contexto, a procura por novos produtos naturais com atividade antibacteriana para a prevenção de doenças bucais é de suma importância para obtenção de um meio efetivo de controle da formação de um biofilme patogênico (YATSUDA, 2004) e da cárie dental.

\subsection{EPIDEMIOLOGIA DA CÁRIE DENTAL NO BRASIL E NO} MUNDO.

A cárie dental é uma das doenças infecciosas mais comuns que afligem o ser humano e tende a permanecer não tratada em muitas áreas subdesenvolvidas, principalmente se considerarmos que, não raro, o paciente só consegue aliviar a sua dor com a extração dentaria (AJDIC et al., 2002). Este quadro configura a cárie dentária como um dos principais problemas de saúde bucal a serem equacionados (MATTOS-GRANER et al., 1998; RAMOSGOMEZ et al., 2002; GOMES et al., 2004; KLEIN et al., 2004).

Segundo SMITH (2002), mesmo com o avanço das soluções profiláticas em relação à doença, crianças entre cinco e nove anos de idade, nos Estados Unidos da América, tiveram pelo menos uma lesão de cárie em seus dentes. O autor afirma que esse percentual aumenta em $84,7 \%$ em adultos com mais de 
dezoito anos de idade e aproximadamente $50 \%$ da população com idade superior a 75 anos, todos apresentando pelo menos uma lesão cariosa na raiz dental. Mais de $2 / 3$ da população México-Americana ou não hispânica (incluindo os Afro-Americanos) tiveram cáries não tratadas. Em alguns países, as cáries dentais tomaram proporções endêmicas como na China, por exemplo, onde 3/4 da população de crianças com cinco anos de idade apresentavam evidências significativas da lesão.

A Organização Mundial de Saúde (OMS) adotou em maio de 1981, indicadores como forma de monitorar a saúde oral da população. Este indicador baseia-se no número de dentes permanentes cariados, perdidos e obturados (CPO) por crianças, com 12 anos de idade e em adultos com idade entre 35 a 44 anos. Para cada item (dente cariado, perdido ou obturado) é computado o valor de 1 escore (PETERSEN, 2003).

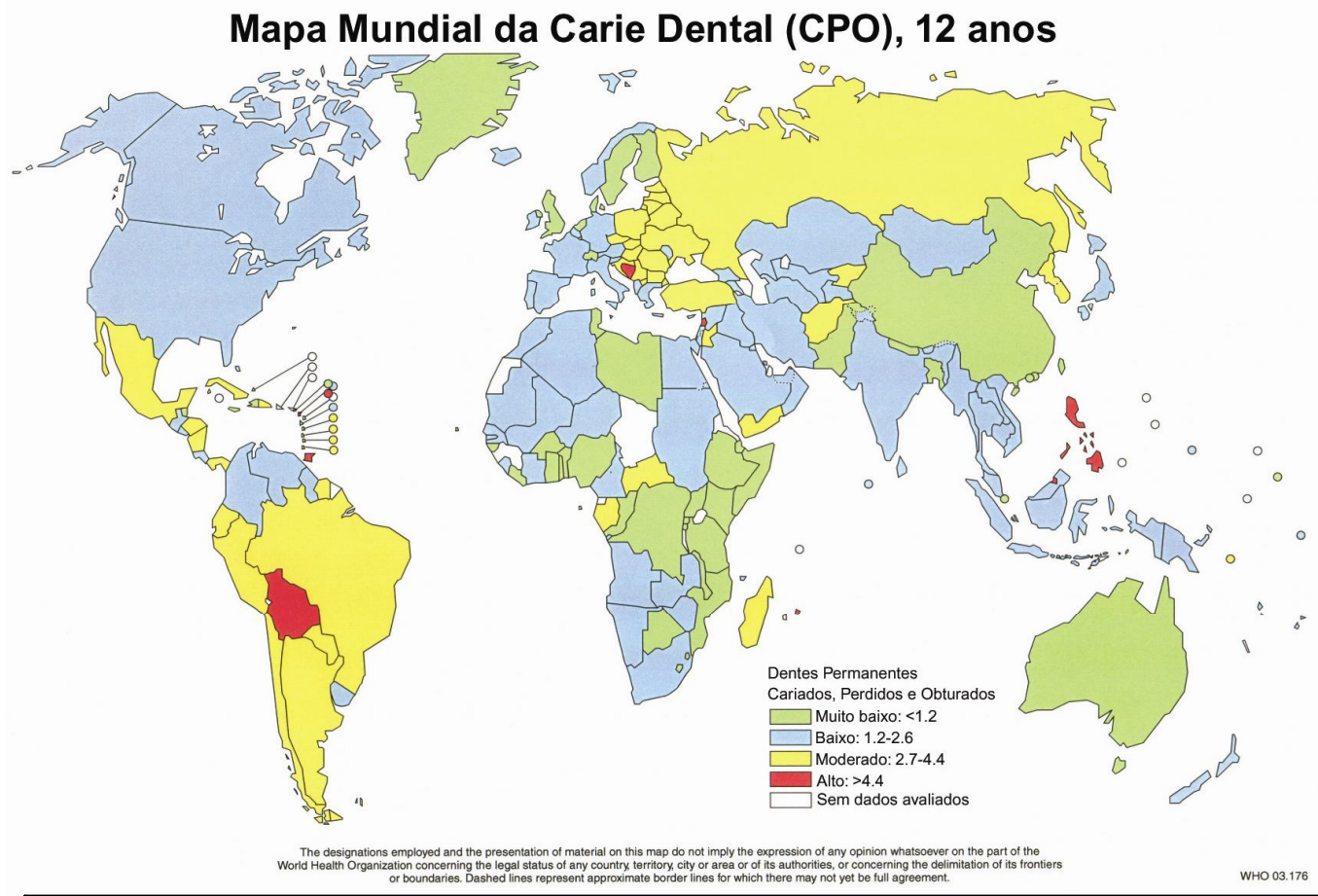

Figura 1 - Mapa mundial da Cárie Dental (CPO) em crianças com 12 anos de idade. (Adaptado PETERSEN, 2003). 
O mesmo estudo foi repetido, porém para adultos com idade entre 35 anos e 44 anos e os resultados estão expressos na Figura 2.

\section{Mapa Mundial da Carie Dental (CPO), 35-44 anos}

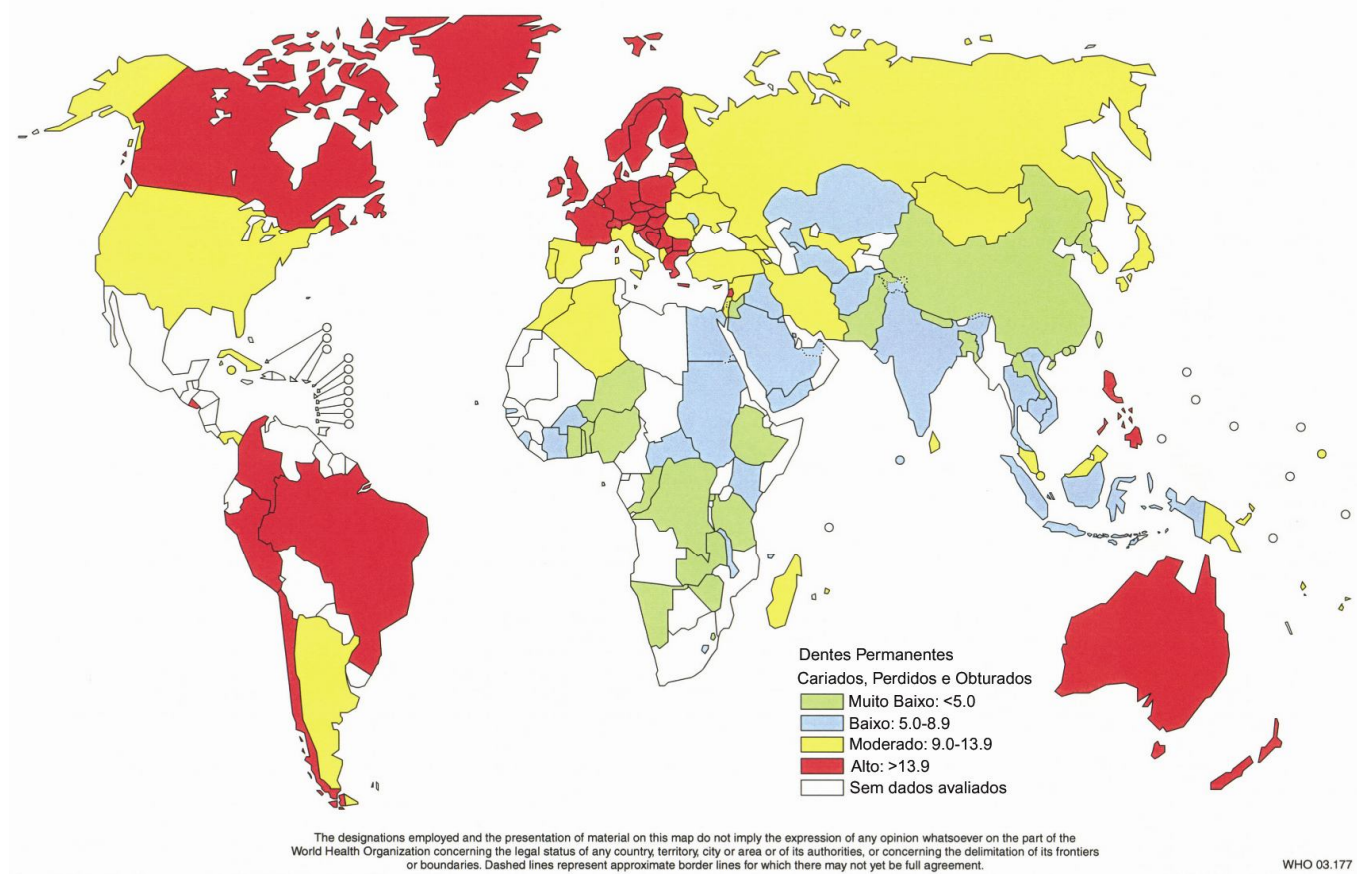

Figura 2 - Mapa mundial da Cárie Dental (CPO) em adultos com idade entre 35 a 44 anos. (Adaptado PETERSEN, 2003).

No Brasil, a saúde bucal constitui ainda um grande desafio aos princípios do Sistema Único de Saúde, principalmente no que se refere à universalização e à eqüidade do atendimento (GOMES et al., 2004).

SMITH (2002) afirma que, cerca de $25 \%$ das crianças de três anos de idade apresentavam muitas lesões cariosas em desenvolvimento e em muitos estados estas lesões eram detectadas em crianças com menos de 18 meses de idade. Este alto grau de lesões afeta diretamente a economia tendo em vista o gasto com a introdução ao flúor em idades precoces.

Embora os últimos dados oficiais sejam de 2002, a Coordenação de Saúde Bucal da SAS/MS divulgou que naquele ano foram gastos mais de $R \$$ 
1,72 bilhão em saúde bucal e até o final de 2003, o Ministério da Saúde esperava investir pouco mais de $\mathrm{R} \$ 2$ bilhões - cerca de $20 \%$ a mais em relação ao ano de 2002.

Na Tabela 1 podem ser observados os índices de dentes permanentes cariados perdidos e obturados de crianças com 12 anos de idade de diferentes estados do Brasil.

\begin{tabular}{|c|c|}
\hline \multicolumn{2}{|c|}{ CPO aos 12 anos em 1996} \\
\hline \multicolumn{2}{|c|}{ (Brasil - 3,06) } \\
\hline Melhores: & Piores: \\
\hline ES - 1,47 & RR - 6,30 \\
\hline SE - 1,50 & RO - 4,99 \\
\hline BA - 1,52 & TO - 4,62 \\
\hline DF - 1,90 & PA - 4,49 \\
\hline RJ - 2,09 & AC - 4,37 \\
\hline
\end{tabular}

Tabela 1 - Índice de CPO em crianças de 12 anos de idade em alguns estados do Brasil, dados de 1996. Fonte: Coordenação de Saúde Bucal da SAS/MS. 


\subsection{A CÁRIE DENTAL, A MICROBIOTA ORAL E O Streptococcus}

mutans.

A microbiota oral é um complexo ecossistema que contém uma grande variedade de espécies microbianas. Na Tabela 2 estão descritas as principais bactérias e o sítio específico de atuação de cada uma delas.

\begin{tabular}{|c|c|c|c|c|}
\hline \multirow{2}{*}{ Grupo Bacteriano } & \multicolumn{4}{|c|}{ Ś́tio } \\
\cline { 2 - 5 } & $\begin{array}{c}\text { Biofilme } \\
\text { Dental }\end{array}$ & Lingua & Saliva & $\begin{array}{c}\text { Linha Cérvico - } \\
\text { Gengival }\end{array}$ \\
\hline Gram-Positive Facultativo cocci & 28.2 & 44.8 & 46.2 & 28.8 \\
\hline Estreptococos & 27.9 & 38.3 & 41.0 & 27.1 \\
\hline S. mutans & $(0-50)$ & $(0-1)$ & $(0-1)$ & $(0-30)$ \\
\hline S. sanguins & $(40-60)$ & $(10-20)$ & $(10-30)$ & $(10-20)$ \\
\hline S. mitior & $(20-40)$ & $(10-30)$ & $(30-50)$ & $(10-30)$ \\
\hline S. salivarius & $(0-1)$ & $(40-60)$ & $(40-60)$ & $(0-1)$ \\
\hline S. milleri & $(3-25)$ & $(0-1)$ & $(0-1)$ & $(14-56)$ \\
\hline Estafilococos & 0.3 & 6.5 & 4.0 & 1.7 \\
\hline Gram-Positivo Anaeróbico cocci & 12.6 & 4.2 & 13.0 & 7.4 \\
\hline Gram-Negativo Anaeróbico cocci & 6.4 & 16.0 & 15.9 & 10.7 \\
\hline Gram-Negativo Facultativo cocci & 0.4 & 3.4 & 1.2 & 0.4 \\
\hline Gram-Positivo Facultativo bacilos & 23.8 & 13.0 & 11.8 & 15.3 \\
\hline Gram-Positivo Anaeróbico bacilos & 18.4 & 8.2 & 4.8 & 20.2 \\
\hline Gram-Negativo Facultativo bacilos & $\mathrm{NE}^{*}$ & 3.2 & 2.3 & 1.2 \\
\hline Gram-Negativo Anaeróbico bacilos & 10.4 & 8.2 & 4.8 & 16.1 \\
\hline Espiroquetas & $\mathrm{NE}^{*}$ & $\mathrm{NE}{ }^{*}$ & $\mathrm{NE}$ & 1.0 \\
\hline
\end{tabular}

Tabela 2 - Adaptada (HAMADA \& SLADE, 1980). Números expressos em porcentagem (\%) do total cultivado do incubado anaerobicamente do Agar-Sangue. Números em parênteses expressos como porcentagem (\%) do número total de estreptococos facultativos.

* Não Encontrado. 
Alguns autores consideram que o Streptococcus mutans são os maiores agentes etiológicos responsáveis pela cárie dental em humanos (GIBBONS \& van HOUTE, 1975a; LOESCHE \& STRAFFON, 1979; LOESCHE, 1986) em conjunto com o grupo sorológico Streptococcus sobrinus (LAMONT et al., 1991, KLEIN et al., 2004). Estudos longitudinais confirmam a relação entre a prevalência da cepa de Streptococcus mutans no biofilme dental e o desenvolvimento das cáries (CARLSSON et al., 1975; MASUDA et al., 1979).

Os estreptococos são organismos facultativos anaeróbicos, Grampositivos que aparecem freqüentemente em cadeias ou pares e são catalasenegativos. Os estreptococos são subdivididos em grupos pelos anticorpos que reconhecem os antígenos de superfície (FOX, 2005).

O nome Streptococcus mutans deriva do fato que as células podem perder sua morfologia em forma de cocos e com freqüência aparecem como bacilos curtos ou como bacilos-cocos (MARSH \& MARTIN, 2005).

O Streptococcus mutans constituem um grupo de espécies cariogênicas orais, que incluem as espécies Streptococcus mutans (sorotipo $c, e, f$ ), $S$. sobrinus (sorotipo d, g), S. cricetus (sorotipo a), S. rattus (sorotipo b), S. downei (sorotipo h), S. macacae, e possivelmente, S. ferus (WHILEY \& BEIGHTON, 1998) e recentemente o sorotipo $k$ (NAKANO et al., 2004). Dentro deste grupo de estreptococos o $S$. mutans e o $S$. sobrinus são os mais freqüentemente encontrados em humanos enquanto que o $S$. cricetus e o $S$. rattus são os únicos detectados raramente (YOO et al. 2005). 


\subsection{O SURGIMENTO, PROPAGAÇÃO E TRANSMISSÃO DO}

\section{Streptococcus mutans.}

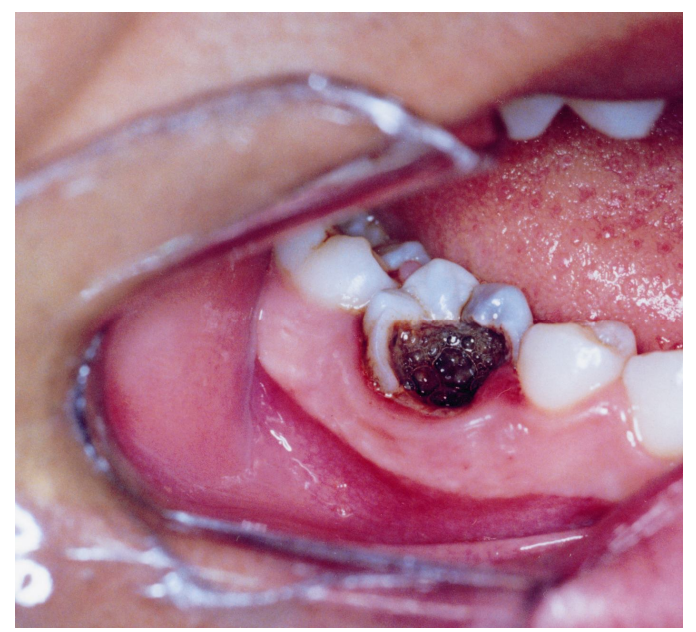

Figura 3 - Foto Intra-Oral do $1^{\circ}$ molar do lado direito, onde nota-se uma extensa lesão cariosa envolvendo parte da face mesial, oclusal e vestibular da coroa dental.

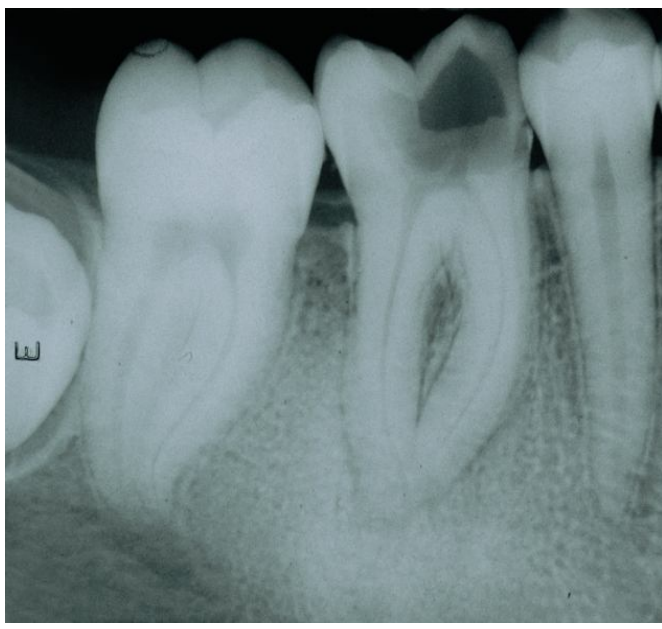

Figura 4 - Radiografia Periapical do mesmo dente em questão onde se evidencia o processo carioso; suspeita de osteomielite crônica esclerosante focal ao redor de seu ápice.

Sabe-se que a cavidade oral se torna habitável rapidamente, logo após o nascimento, pelos estreptococos que têm a capacidade de colonização de superfícies mucosas (CARLSSON et al. 1967, THYLSTRUP \& FEJERSKOV, 1998; SMITH et al., 1993; MARSH \& MARTIN, 2005).

Embora TANZER e seus colaboradores (2001) tivessem relatado que a colonização por Streptococcus mutans ocorria somente após a erupção do primeiro dente e o sítio preferencial de colonização era o próprio dente, o grupo de SMITH (1993) demonstrou que o Streptococcus mitis e o Streptococcus salivarius são identificados com consistência no epitélio oral de recém-nascidos com apenas poucas semanas de vida. 
A cárie demonstrou seu caráter infecto-contagioso por meio de filhotes de hamsters cujas mães foram tratadas com antibióticos durante o período de amamentação. Tais roedores não desenvolveram a doença, mesmo recebendo uma dieta com grande potencial cariogênico, contudo desenvolveram a doença quando colocados em contato com hamsters infectados ou com suas fezes, ou ainda quando inoculados com material proveniente das placas dentárias destes animais (KEYS, 1960; THYLSTRUP \& FEJERSKOV, 1998; WEYNE, 2000).

Um fator a ser considerado é o mecanismo de aderência à película salivar, ou ao biofilme previamente instalado (GIBBSON et al.,1986; LAMONT \& ROSAN, 1990). O Streptococcus mutans podem aderir-se às mucinas salivares de alto peso molecular, que constituem parte da película salivar do esmalte (GIBBSON \& HAY, 1989; KISHIMOTO et al., 1989). Os Streptococcus mutans podem ainda aderir-se às cepas de Streptococcus sanguis, Streptococcus mitis e Actinomyces viscosus, que são os microrganismos predominantes durante a formação primária do biofilme dental (LAMONT \& ROSAN, 1990).

Estudos indicam a transmissão intra-familiar do Streptococcus mutans, baseados no sorotipo e no filtrado dos bacteriotipos isolados da mãe e dos filhos (KÖHLER \& BRATTHALL, 1978; BERKOWITZ et al., 1975; BERKOWITZ \& JORDAN, 1975, KLEIN et al., 2004; MARSH \& MARTIN, 2005). 


\subsection{A PROBLEMÁTICA DA CÁRIE E A SAÚDE GERAL.}

Os efeitos nocivos provenientes da cárie não atingem tão somente os dentes, existindo inúmeras injúrias que o nosso organismo pode sofrer depois da cárie instalada e não tratada (processo infeccioso crônico), dentre as quais a mais importante é a endocardite bacteriana, responsável por 45 a $80 \%$ de todos os casos que envolvem válvulas naturais (DURACK, 1995; PAlK et al., 2003).

O grupo estreptocócico viridans, incluindo os Streptococcus mutans, são também responsáveis pela endocardite bacteriana em humanos.

A endocardite bacteriana é uma infecção que ameaça a vida e ocorre quando, por meio de extrações dentais, escovação e mastigação de alimentos (CHIA et al., 2004), o S. mutans entra em contato com o fluído sangüíneo (NAKANO et al., 2004) e adere às válvulas previamente danificadas do coração (DURACK, 1995). Seu desenvolvimento depende da capacidade das colônias dos estreptococos de induzir a formação de vegetações, representadas por uma matriz fribrino-plaquetária, que invadem o sistema imune do ser humano (CHIA et al., 2004).

As várias espécies de estreptococos orais, dentre elas o Streptococcus mutans do sorotipo $c$, foram capazes de induzir a agregação plaquetária das várias espécies, incluindo ratos, coelhos, e dos seres humanos (CHIA et al., 2004). 


\subsection{VENENOS DE SERPENTE.}

O estudo dos venenos de serpentes tem propiciado a elucidação de diversos mecanismos farmacológicos e auxiliado muito na indústria farmacêutica em busca de novos fármacos, como por exemplo, a elaboração da molécula de um dos medicamentos mais vendidos para controle da pressão arterial, o Captopril. Este medicamento foi obtido a partir de um peptídeo isolado do veneno da serpente Bothrops jararaca com demonstrada eficiência em inibir a conversão de angiotensina (SANT'ANA, 2005).

Os venenos ofídicos são misturas complexas, constituídas principalmente por proteínas, peptídeos e, em pequenas proporções, carboidratos, lipídeos, nucleotídeos, aminoácidos e componentes inorgânicos (MEIER, 1990). Os principais componentes tóxicos são enzimas e outras proteínas que podem levar a diversos efeitos bioquímicos, imunológicos, farmacológicos e patológicos, podendo induzir lesões no tecido local, efeito sistêmico e morbidade ou morte relacionada com a toxicidade do veneno (ROSENFELD, 1991).

No Brasil são encontrados quatro gêneros de serpentes peçonhentas de importância médica das quais três, pertencentes à família Viperidae que são: Bothrops (jararacas), Crotalus (cascavéis) e Lachesis (surucucus) e um pertencente à família Elapidae que é Micrurus (corais) (BAPTISTA, 2004), e apenas duas dessas famílias são conhecidas como peçonhentas (Elapidae e Viperidae), isto é, aquelas que produzem toxinas em glândulas especializadas e têm aparelhos apropriados para inoculá-las, ocasionando intoxicações sérias no homem e em outras espécies animais (SANT'ANA, 2005). 
A família dos Elapidae é encontrada em regiões tropicais e subtropicais do mundo todo, inclusive no oceano Índico e no Pacífico (WARRELL, 1993). São caracterizados por possuírem dentição do tipo proteróglifa (BARRAVIEIRA \& FERREIRA JÚNIOR, 2007). Atualmente 61 gêneros que incluem 231 espécies são reconhecidos. Todas as serpentes da família Elapidae são venenosas e potencialmente mortais. Seu veneno na sua maioria são neurotóxicos e considerados mais perigosos do que muitos venenos proteolítica de víboras (WARRELL, 1993; WHITE, 2000).

A família dos Viperidae, vulgarmente designado por víboras, embora o termo viperides seja mais específico e que os distingue dos viperíneos (subfamília Viperinae). Estas serpentes são encontradas em todo o mundo, exceto na Austrália e Madagascar. As Viperidae, com aproximadamente 215 espécies, inclui as subfamílias Viperinae e Crotalinae, que possuem o mais complexo aparelho peçonhífero, conhecido como solenóglifa (WARRELL, 1993; WHITE, 2000; BARRAVIEIRA \& FERREIRA JÚNIOR, 2007). Ao contrário do veneno da família dos elapídeos que desativam a contração muscular e causam a paralisia, o veneno dos viperídeos que tipicamente possuem em abundância uma enzima chamada de protease, induzem a sintomas como dor, inchaço e necrose local forte, perda de sangue cardiovascular complicada por danos coagulopatia, e ruptura do sistema de coagulação sanguínea (WARRELL, 1993).

Neste estudo foram analisados venenos de várias espécies do mundo, sendo a maior parte deles provenientes da Austrália, conforme pode-se observar na Tabela 3, a taxonomia, geografia e principais ações dos venenos em acidentes ofídicos em humanos. 


\begin{tabular}{|c|c|c|c|}
\hline Família & $\begin{array}{l}\text { Gênero e } \\
\text { Espécie }\end{array}$ & Geografia & Ação do Veneno ${ }^{\dagger}$ \\
\hline Elapidae & $\begin{array}{l}\text { Acanthophis } \\
\text { antarcticus }\end{array}$ & $\begin{array}{c}\text { Austrália, Nova Guiné e llhas } \\
\text { Vizinhas }\end{array}$ & Neurotóxico \\
\hline Elapidae & $\begin{array}{l}\text { Hoplocephalus } \\
\text { stephensi }\end{array}$ & $\begin{array}{l}\text { Austrália (Nova Wales do Sul e } \\
\text { Ilha da Rainha) }\end{array}$ & $\begin{array}{l}\text { Neurotóxico e } \\
\text { Hematotóxico }\end{array}$ \\
\hline Elapidae & $\begin{array}{c}\text { Naja } \\
\text { melanoleuca }\end{array}$ & $\begin{array}{l}\text { África (principalmente nas } \\
\text { florestas do Sub-Sahara) }\end{array}$ & Neurotóxico e Miotóxico \\
\hline Elapidae & $\begin{array}{c}\text { Naja } \\
\text { mossambica }\end{array}$ & África & Neurotóxico e Miotóxico \\
\hline Elapidae & $\begin{array}{l}\text { Notechis ater } \\
\text { niger }\end{array}$ & Austrália (Região Sul) & $\begin{array}{c}\text { Neurotóxico, Miotóxico e } \\
\text { Hematotóxico }\end{array}$ \\
\hline Elapidae & $\begin{array}{l}\text { Notechis } \\
\text { scutatus }\end{array}$ & $\begin{array}{c}\text { Austrália (Região Leste, Sul e } \\
\text { Tasmânia) }\end{array}$ & $\begin{array}{c}\text { Neurotóxico, Miotóxico e } \\
\text { Hematotóxico }\end{array}$ \\
\hline Elapidae & $\begin{array}{c}\text { Oxyuranus } \\
\text { microlepidotus }\end{array}$ & $\begin{array}{c}\text { Austrália (Região Central e parte } \\
\text { do Sudeste) }\end{array}$ & Neurotóxico \\
\hline Elapidae & $\begin{array}{l}\text { Oxyuranus } \\
\text { scutellatus }\end{array}$ & $\begin{array}{c}\text { Austrália, Costa Sul da Papua e } \\
\text { Nova Guiné }\end{array}$ & $\begin{array}{l}\text { Neurotóxico e } \\
\text { Hematotóxico }\end{array}$ \\
\hline Elapidae & $\begin{array}{l}\text { Pseudechis } \\
\text { colletti }\end{array}$ & Austrália (Ilha da Rainha) & $\begin{array}{c}\text { Neurotóxico, Citotóxico e } \\
\text { Hematotóxico }\end{array}$ \\
\hline Elapidae & $\begin{array}{l}\text { Pseudechis } \\
\text { australis }\end{array}$ & $\begin{array}{c}\text { Austrália (Exceto Vitória e } \\
\text { Tasmânia) }\end{array}$ & $\begin{array}{c}\text { Neurotóxico, Citotóxico e } \\
\text { Hematotóxico }\end{array}$ \\
\hline Elapidae & $\begin{array}{l}\text { Pseudechis } \\
\text { guttatus }\end{array}$ & $\begin{array}{l}\text { Austrália (Costa Leste) e } \\
\text { Indonésia }\end{array}$ & $\begin{array}{c}\text { Neurotóxico, Miotóxico e } \\
\text { Hematotóxico }\end{array}$ \\
\hline Elapidae & $\begin{array}{l}\text { Pseudechis } \\
\text { porphyriacus }\end{array}$ & $\begin{array}{l}\text { Austrália (Costa Nordeste, } \\
\text { Central e Sudeste) }\end{array}$ & $\begin{array}{c}\text { Neurotóxico, Miotóxico e } \\
\text { Hematotóxico }\end{array}$ \\
\hline Elapidae & $\begin{array}{l}\text { Pseudonaja } \\
\text { textilis }\end{array}$ & $\begin{array}{l}\text { Austrália (Nova Wales do Sul e } \\
\text { Ilha da Rainha e Vitória) }\end{array}$ & $\begin{array}{c}\text { Neurotóxico, Miotóxico e } \\
\text { Hematotóxico }\end{array}$ \\
\hline Viperidae & $\begin{array}{c}\text { Bothrops } \\
\text { moojeni }\end{array}$ & $\begin{array}{c}\text { Brasil (Regiões de Floresta e } \\
\text { Mata) }\end{array}$ & $\begin{array}{c}\text { Neurotóxico, Miotóxico e } \\
\text { Hematotóxico }\end{array}$ \\
\hline Viperidae & $\begin{array}{l}\text { Bothrops } \\
\text { jararacussu }\end{array}$ & $\begin{array}{c}\text { Brasil (Regiões de Floresta e } \\
\text { Mata) }\end{array}$ & $\begin{array}{c}\text { Neurotóxico, Miotóxico e } \\
\text { Hematotóxico }\end{array}$ \\
\hline Viperidae & $\begin{array}{l}\text { Agkistrodon } \\
\text { bilineatus }\end{array}$ & México e America Central & Hematotóxico \\
\hline
\end{tabular}

Tabela 3 - Taxonomia das serpentes utilizadas, bem como suas predileções geográficas e principais características do veneno.

$\dagger$ Veneno bruto. 
A ação bactericida dos venenos na forma bruta, já fora vista por STILES e cols., em 1991 em venenos de diversas espécies. Fazendo uma correlação com os venenos utilizados por nós, foi possível confeccionar a Tabela 4, onde pode-se observar a taxonomia e a ação bactericida.

\begin{tabular}{|c|c|c|c|c|c|c|}
\hline \multirow{2}{*}{ Família } & \multirow{2}{*}{$\begin{array}{l}\text { Gênero e } \\
\text { Espécie }\end{array}$} & \multicolumn{5}{|c|}{ Ação Bactericida } \\
\hline & & E. coli & A. hydrophila & S. aureus & $P$. aeruoginosa & B. subtilis \\
\hline Elapidae & $\begin{array}{l}\text { Acanthophis } \\
\text { antarcticus }\end{array}$ & - & - & - & - & + \\
\hline Elapidae & $\begin{array}{c}\text { Hoplocephalus } \\
\text { stephensi }\end{array}$ & \# & \# & \# & \# & \# \\
\hline Elapidae & $\begin{array}{c}\text { Naja } \\
\text { melanoleuca }\end{array}$ & - & - & - & - & - \\
\hline Elapidae & $\begin{array}{c}\text { Naja } \\
\text { mossambica }\end{array}$ & - & + & + & - & + \\
\hline Elapidae & $\begin{array}{l}\text { Notechis ater } \\
\text { niger }\end{array}$ & \# & \# & \# & \# & \# \\
\hline Elapidae & $\begin{array}{l}\text { Notechis } \\
\text { scutatus }\end{array}$ & - & + & + & + & + \\
\hline Elapidae & $\begin{array}{c}\text { Oxyuranus } \\
\text { microlepidotus }\end{array}$ & \# & \# & \# & \# & \# \\
\hline Elapidae & $\begin{array}{l}\text { Oxyuranus } \\
\text { scutellatus }\end{array}$ & \# & \# & \# & \# & \# \\
\hline Elapidae & $\begin{array}{l}\text { Pseudechis } \\
\text { colletti }\end{array}$ & \# & \# & \# & \# & \# \\
\hline Elapidae & $\begin{array}{l}\text { Pseudechis } \\
\text { australis }\end{array}$ & + & + & + & - & + \\
\hline Elapidae & $\begin{array}{l}\text { Pseudechis } \\
\text { guttatus }\end{array}$ & \# & \# & \# & \# & $\#$ \\
\hline Elapidae & $\begin{array}{l}\text { Pseudechis } \\
\text { porphyriacus }\end{array}$ & \# & \# & \# & \# & \# \\
\hline Elapidae & $\begin{array}{l}\text { Pseudonaja } \\
\text { textilis }\end{array}$ & \# & \# & \# & \# & \# \\
\hline Viperidae & $\begin{array}{c}\text { Bothrops } \\
\text { moojeni }\end{array}$ & \# & \# & \# & \# & \# \\
\hline Viperidae & $\begin{array}{c}\text { Bothrops } \\
\text { jararacussu }\end{array}$ & \# & \# & \# & \# & \# \\
\hline Viperidae & $\begin{array}{l}\text { Agkistrodon } \\
\text { bilineatus }\end{array}$ & \# & \# & \# & \# & \# \\
\hline
\end{tabular}

Tabela 4 - Taxonomia das serpentes utilizadas em comparativo com sua ação bactericida.

* Baseado nas bactérias testadas por STILES et al., 1991.

+ Apresenta ação bactericida.

- Não apresenta ação bactericida.

\# Veneno não utilizado. 
Os componentes protéicos ativos presentes nos venenos de serpentes, em geral, podem ser classificados como enzimáticos e não enzimáticos. Dentre os componentes enzimáticos pode-se citar a fosfolipase $A_{2}\left(P L A_{2}\right)$, a fosfodiesterase, arginina éster hidrolase, acetilcolinesterase, 5' nucleotidase, hialuronidase, a L-aminoácido oxidase e outras (TAN \& SAIFUDDIN, 1991; BARBOSA et al., 2005).

As fosfolipases $A_{2}$ são uma classe de enzimas cálcio-dependentes que catalisam a hidrólise da ligação 2-acil-ester do 3-sn-fosfolipídeo, sendo constituídas por uma cadeia simples de 122 resíduos de aminoácidos, com massa molecular em torno de $14000 \mathrm{kDa}$ (CHO et al, 1988). Essas enzimas podem ser isoladas de venenos de serpentes, apresentando propriedades tóxicas e digestivas; venenos de mamíferos e, mais recentemente, de extratos de plantas medicinais (LIZANO et al, 2003).

A L-aminoácido oxidase (L-aminoácido: $\mathrm{O}_{2}$ oxidoredutase, EC 1.4.3.2) é o componente responsável pela cor amarela de alguns venenos ofídicos, pois apresenta dois moles de FAD por mol de enzima como grupo prostético. A enzima nativa é uma glicoproteína dimérica de peso molecular de aproximadamente $130 \mathrm{KDa}$ constituída por duas subunidades de peso molecular de aproximadamente $70 \mathrm{KDa}$ cada e interligadas de forma não covalente (JIMENEZ-PORRAS, 1970). 
Esta enzima catalisa a oxidação desaminativa de L-aminoácidos, produzindo o cetoácido correspondente, peróxido de hidrogênio e amônia (TAN \& SAIFUDDIN, 1991; PESSATI et al., 1995, KARTHIKEYAN et al., 2004) como descreve a seguinte reação:

\section{$\mathrm{LAO}+\mathrm{H}_{2} \mathrm{O} \longrightarrow \alpha$ cetoácido $+\mathrm{NH}_{3}+\mathrm{H}_{2} \mathrm{O}_{2}$}

\subsection{A RADIAÇÃO IONIZANTE.}

A partir de estudos com os efeitos da radiação ionizante sobre sistemas biológicos, foram considerados seus efeitos sobre a molécula da água, por ser a mais abundante neste tipo de sistema. Assim, materiais biológicos irradiados em solução geram espécies moleculares e radicais livres, como os representados abaixo:

$$
\mathrm{H}_{2} \mathrm{O} \longrightarrow \mathrm{OH}^{-}, \mathrm{e}_{\mathrm{aq}}{ }^{-}, \mathrm{H}_{2} \mathrm{O}_{2}, \mathrm{H}_{2}
$$

Quando em solução, esses produtos da radiólise da água podem se difundir e reagir com macromoléculas bioquimicamente ativas e causar perda de atividade biológica (NASCIMENTO et al., 1996; ROGERO \& NASCIMENTO, 1995). No caso da radiação ionizante, a espécie mais reativa gerada pela radiólise da água é o radical hidroxila $\left(\mathrm{OH}^{\circ}\right)$ (CHAPMAN, 1993), que junto com o ânion superóxido $\left(\mathrm{O}_{2}{ }^{\bullet}\right)$ e peróxido de hidrogênio $\left(\mathrm{H}_{2} \mathrm{O}_{2}\right)$ são capazes de produzir dano às moléculas (GREENSTOCK, 1981).

Alterações químicas de alguns aminoácidos, quebra de pontes de dissulfeto, mudanças conformacionais devido aos distúrbios nas pontes de hidrogênio e ligações cruzadas na cadeia polipeptídica podem ocorrer e levar à 
perda de atividade biológica. Porém as propriedades antigênicas são aquelas que se apresentam mais radiorresistentes (GUARNIERI, 1992) permitindo que a radiação gama atenue a toxicidade de diversas toxinas isoladas ou venenos brutos mantendo, contudo, as propriedades antigênicas e imunogênicas (NASCIMENTO et al., 1996; ROGERO \& NASCIMENTO, 1995; CARDI et al., 1997). Podem ainda ocorrer alterações oxidativas decorrentes da interação dos radicais livres primários, com a molécula de proteína, alterando sua estrutura e podendo conferir a mesma, cargas negativas (WALES \& KUSEL, 1992).

Uma vez que os venenos de serpentes são constituídos basicamente de proteínas, a possibilidade de usar a radiação ionizante como ferramenta para modificar algumas propriedades das toxinas já foram estudados por LAUHATIRANANANDA e cols. em 1969 e por SALAFRANCA em 1973.

Estudos com proteínas submetidas à ação da radiação gama, têm demonstrado a eficiência do método como ferramenta na produção de melhores imunógenos, somando a vantagem de não adicionar novas moléculas à amostra durante o processo, como no caso do uso de agentes físicos ou químicos e a melhoria de antigenicidade de muitas proteínas (BAPTISTA, 2004).

De posse destas informações e considerando-se a experiência dos pesquisadores do Centro de Biotecnologia do IPEN/CNEN-SP com os venenos animais e, particularmente, publicações relacionadas à utilização de venenos de serpentes para inibir crescimento de protozoários (TEMPONE et al., 2001) vislumbrou-se a possibilidade de desenvolver estudos da ação dos venenos 
sobre o Streptococcus mutans, que conforme já descrito, é o principal agente responsável pela cárie dentária.

Embora o avanço das pesquisas em relação a esta doença tenha permitido melhor controle de sua instalação bem como a melhor compreensão do processo do desenvolvimento e evolução nos seus estágios mais precoces (SCABAR et al., 2004), ainda não se obteve a solução para este problema de saúde pública.

Desta forma, estudos que busquem componentes, principalmente os naturais, que combatam os patógenos bucais só farão contribuir para o avanço no desenvolvimento de novas drogas mais eficazes e economicamente viáveis para o tratamento e prevenção da cárie dentária. 


\section{OBJETIVO}

\subsection{GERAL.}

Caracterizar e avaliar venenos de diferentes serpentes das Famílias Viperidae e Elapidae quanto à capacidade de inibição do crescimento do principal agente causal da cárie: Streptococcus mutans.

\subsection{ESPECÍFICOS.}

- Identificar os venenos com capacidade inibitória do crescimento de $S$. mutans;

- Identificar componentes do veneno com ação inibitória do crescimento;

- Avaliar a participação do peróxido de hidrogênio na capacidade de inibição do crescimento bacteriano. 


\section{MATERIAL E MÉTODOS}

\subsection{REAGENTES.}

Todos os reagentes utilizados neste trabalho foram obtidos comercialmente e são de qualidade pró-análise.

\subsection{VENENOS OFÍDICOS.}

Os venenos de serpentes foram fornecidos pelo Dr. Peter J. Mirtschin (Venom Supplies Pty Ltd.), pelo Instituto Butantan e CEVAP (Centro de Estudos de Venenos e Animais Peçonhentos), na forma cristalizada. As serpentes utilizadas para a extração dos venenos podem ser consultadas na Tabela 5.

\begin{tabular}{|c|c|c|}
\hline Família & Gênero e Espécie & Nome Popular \\
\hline Elapidae & Acanthophis antarcticus & Common Death Adder \\
\hline Elapidae & Hoplocephalus stephensi & Stephen's Banded Snake \\
\hline Elapidae & Naja melanoleuca & Black Cobra \\
\hline Elapidae & Naja mossambica & Sipitting Cobra \\
\hline Elapidae & Notechis ater niger & Peninsula Tiger \\
\hline Elapidae & Notechis scutatus & Mainland Tiger \\
\hline Elapidae & Oxyuranus microlepidotus & Island Taipan \\
\hline Elapidae & Oxyuranus scutellatus & Coastal Taipan \\
\hline Elapidae & Pseudechis colletti & Collett's Snake \\
\hline Elapidae & Pseudechis australis & King Brown \\
\hline Elapidae & Pseudechis guttatus & Spotted Black \\
\hline Elapidae & Pseudechis porphyriacus & Red Bellied Black Snake \\
\hline Elapidae & Pseudonaja textilis & Eastern Brown Snake \\
\hline Viperidae & Bothrops moojeni & Caissaca \\
\hline Viperidae & Bothrops jararacussu & Jararaca \\
\hline Viperidae & Agkistrodon bilineatus & Tropical Moccasin \\
\hline
\end{tabular}

Tabela 5 - Taxonomia das serpentes utilizadas, bem como seu nome popular. 
MOSCA, R.C., 2008

\subsection{FONTE DE RADIAÇÃO E IRRADIAÇÃO DE VENENOS.}

Para o processo de irradiação das fosfolipases dos venenos ofídicos ativos, foi utilizada uma fonte de ${ }^{60} \mathrm{Co}$ (Gamma Cell 220, Atomic Energy Agency of Canadá), disponível no Centro de Tecnologia das Radiações do Instituto de Pesquisas Energéticas e Nucleares IPEN/CNEN-SP. As enzimas do tipo $\mathrm{PLA}_{2}$ dos venenos que apresentaram capacidade de inibir o crescimento do Streptococcus mutans foram submetidos aos efeitos da radiação gama de ${ }^{60} \mathrm{Co}$ com a dose de 2 kGy (taxa de dose de 5,17 kGy/hora).

\subsection{BACTÉRIAS E CURVA DE CRESCIMENTO BACTERIANO.}

Cepas da bactéria de Streptococcus mutans (ATCC 25175) foram fornecidas pelo departamento de Microbiologia Oral do Instituto de Ciências Biológicas (I.C.B.) da Universidade de São Paulo.

Estas cepas foram cultivadas em estufa a $37^{\circ} \mathrm{C}$ com liberação de $\mathrm{CO}_{2}$ constante e em anaerobiose, em tubos de ensaios contendo $15 \mathrm{~mL}$ de meio líquido de $\mathrm{BHI}$ (Brain Heart Infusion) (Difco ${ }^{\circledR}$-Detroit- Michigan), donde foi retirada uma alíquota de $100 \mu \mathrm{L}$ a cada 30 minutos e verificada a densidade óptica por absorvância em filtro de 595 nm para determinar a curva logarítmica e encontrar a fase LOG (crescimento). Posteriormente, as cepas foram cultivadas em tubos de ensaios (triplicata) contendo $5 \mathrm{~mL}$ de meio liquido $\mathrm{BHI}$ e este conteúdo foi semeado em placas de Petri de $5 \mathrm{~cm}$ de diâmetro, contendo $15 \mathrm{~mL}$ de meio sólido BHI/Agar, a fim de homogeneizar o conteúdo. Este processo foi realizado para retirar apenas uma colônia isolada da bactéria (CFU). Retirada uma colônia isolada (CFU), foi feito o cultivo novamente em 
outro tubo de ensaio seguindo o mesmo protocolo descrito anteriormente. A incubação foi feita por um período de 26 horas e a concentração de bactérias $\left(\mathrm{CFU} / \mathrm{mL}^{-1}\right)$ foi determinada pela leitura de $200 \mu \mathrm{L}$ do meio com bactérias em leitor de microplacas com filtro de $595 \mathrm{~nm}$.

\subsection{ANTIBIOGRAMA DOS VENENOS.}

Para se observar a presença de atividade antibacteriana dos 16 venenos sobre as amostras de Streptococcus mutans, 16 placas de Petri de $5 \mathrm{~cm}$ de

diâmetro foram preparadas com meio de cultivo sólido Mueller Hinton/Agar (15 $\mathrm{mL}$ ) e depois, em cada uma das placas, foi adicionado um concentrado contendo $200 \mu \mathrm{L}$ de meio líquido de $\mathrm{BHI}$ com o cultivo de uma colônia isolada de Streptococcus mutans (conforme supracitado). Posteriormente foram inseridos cinco discos, eqüidistantes, de papel absorvente de $6 \mathrm{~mm}$ de diâmetro em cada placa de Petri com $15 \mu \mathrm{L}$ de cada veneno (2 mg/mL). Passadas 26 horas foram feitas observações quanto à presença ou ausência de halos de inibição do crescimento bacteriano em torno dos discos contendo as amostras. Todos os experimentos foram realizados em triplicata.

\subsection{DOSAGEM DE PROTEÍNAS.}

Os venenos de serpentes que apresentaram poder de inibição sobre o S. mutans tiveram sua concentração protéica determinada pelo método BRADFORD (1976). Diversas diluições de uma solução de albumina bovina foram utilizadas na determinação da curva de calibração obedecendo à seguinte equação: [(Absorvância a 595 nm x 1,361) - 0,08]. 
Este método baseia-se no fato de que determinados aminoácidos hidrofóbicos podem se ligar ao corante Coomassie Brilhant Blue - 250, presente no reagente de BRADFORD, formando um complexo corante proteína. Esta proteína, quando em meio altamente ácido, acaba interferindo na absorvância do corante, ocasionando uma modificação proporcional da coloração que é detectável no comprimento de onda de $595 \mathrm{~nm}$.

As amostras dos venenos efetivos, bem como as frações ativas (picos) foram diluídas (fator $=4$ ) em solução de PBS $(1 \mathrm{x})$ e em seguida adicionou-se $20 \mu \mathrm{L}$ destas amostras em $1 \mathrm{~mL}$ de reagente de Bradford e $50 \mu \mathrm{L}$ de solução de $\mathrm{NaOH}(1 \mathrm{M})$.

Posteriormente, realizou-se a leitura espectrofotométrica a $595 \mathrm{~nm}$ (Ultrospec 3000 - Pharmacia Biotech ${ }^{\circledR}$ ) a partir da qual se calculou a concentração protéica.

\subsection{DETERMINAÇÃO DA CONCENTRAÇÃO INIBITÓRIA MÍNIMA (MIC) DOS VENENOS COM CAPACIDADE DE INIBIR O CRECIMENTO DE Streptococcus mutans.}

Para a determinação da Concentração Inibitória Mínima (MIC) dos venenos sobre as bactérias Streptococcus mutans, estas foram incubadas (concentração de aproximadamente $2,63 \times 10^{6} \mathrm{CFU} / \mathrm{mL}^{-1}$ ) em placas de 96 poços com diferentes quantidades dos venenos com ação inibitória, na concentração máxima de $4 \times 10^{-2} \mu \mathrm{g} / \mathrm{mL}$, seguindo uma diluição seriada de fator 1:2, na presença e na ausência de catalase $(2 \mathrm{mg} / \mathrm{mL})$, como pode ser observado na Tabela 6, bem como a quantidade de veneno utilizada. 
O período de incubação foi de 26 horas com leituras espectrofotométricas a $595 \mathrm{~nm}$ (Ultrospec 3000 - Pharmacia Biotech ${ }^{\circledR}$ ) a cada 1 hora aproximadamente. Os resultados obtidos foram compilados relacionando-se grau de turbidez em função do tempo.

\begin{tabular}{|c|c|c|c|c|c|c|c|c|c|c|c|c|}
\hline oçC & 1 & & 3 & 4 & 5 & 6 & 7 & 8 & 9 & 10 & 11 & 12 \\
\hline $\mathbf{A}^{\circ}$ & \multirow{4}{*}{ 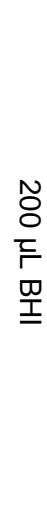 } & \multirow{4}{*}{ 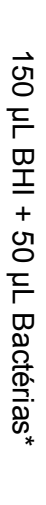 } & \multirow[b]{4}{*}{ D } & \multirow{4}{*}{ 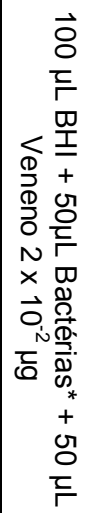 } & \multirow{4}{*}{ 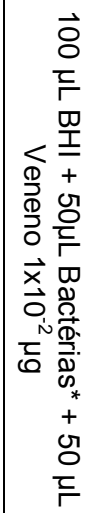 } & \multirow{4}{*}{ 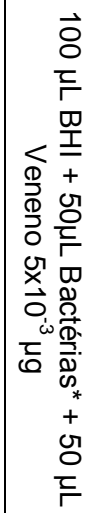 } & \multirow{4}{*}{ 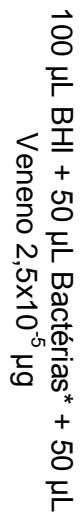 } & \multirow{4}{*}{ 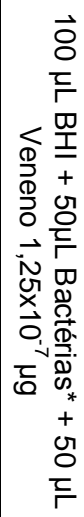 } & \multirow{4}{*}{ 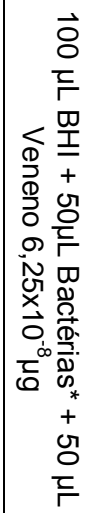 } & \multirow{4}{*}{ 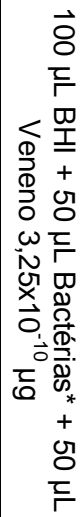 } & \multirow{4}{*}{ 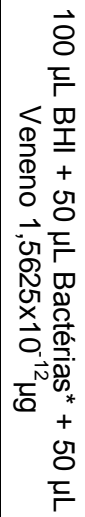 } & \multirow{4}{*}{ 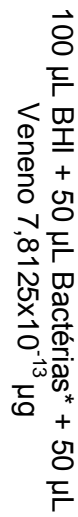 } \\
\hline $\mathbf{B}^{\circ}$ & & & & & & & & & & & & \\
\hline $\mathbf{C}^{\circ}$ & & & & & & & & & & & & \\
\hline 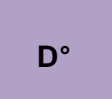 & & & & & & & & & & & & \\
\hline
\end{tabular}

- Exames realizados em duplicata

- Bactérias a concentração de $\approx 2,63 \times 10^{6} \mathrm{CFU} / \mathrm{mL}^{-1}$

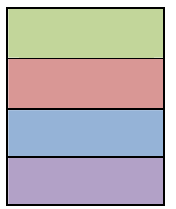

Poços preenchidos s/ catalase (Bothrops jararacussu)

Poços preenchidos c/ $50 \mu \mathrm{L}$ de catalase (Bothrops jararacussu)

Poços preenchidos s/ catalase (Bothrops moojenı)

Poços preenchidos c/ $50 \mu \mathrm{L}$ de catalase (Bothrops moojeni)

Tabela 6 - Protocolo utilizado em placa de 96 poços (8 linhas x 12 colunas) para leitura espectrofotométrica em filtro de $565 \mathrm{~nm}$ 


\subsection{FRACIONAMENTO POR CROMATOGRAFIA DE EXCLUSÃO MOLECULAR DOS VENENOS EFETIVOS.}

Os venenos que apresentaram capacidade de inibir o crescimento do S.mutans foram fracionados por cromatografia de exclusão molecular, a fim de se obter a fração ou frações responsáveis pela atividade.

O veneno total $(4 \mathrm{mg})$ foi diluído em $1 \mathrm{~mL}$ de tampão de PBS - $\mathrm{pH} 7$ e centrifugado a $10.000 \mathrm{~g}$ (centrífuga Centrimicro 242 - Fanen) por 5 minutos. Posteriormente, o sobrenadante, foi aplicado em uma coluna Superdex 200 prep. grande (1,6 x $70 \mathrm{~cm}$ - Pharmacia), previamente equilibrada com $500 \mathrm{~mL}$ do mesmo tampão. O sistema foi acoplado a um FPLC (Fluid Pressure Liquid Chromatography) com fluxo constante de $1 \mathrm{~mL} / \mathrm{min}$. $\mathrm{O}$ eluato foi coletado (1 ml/tubo) em um coletor FRAC 200 (Pharmacia), acompanhado-se a leitura de D.O. em $280 \mathrm{~nm}$.

\subsection{ANTIBIOGRAMA DAS FRAÇÕES DOS VENENOS DE Bothrops} moojeni E Bothrops jararacussu.

Com o intuito de avaliar a capacidade de inibição do crescimento do $S$. mutans pelas frações dos venenos das serpentes Bothrops moojeni e Bothrops jararacussu, 11 placas de Petri de $5 \mathrm{~cm}$ de diâmetro foram preparadas com meio de cultivo sólido Mueller Hinton/Agar (15 mL). Em cada uma das placas fora adicionado um concentrado contendo $200 \mu \mathrm{L}$ de meio líquido de BHI com o cultivo de uma colônia isolada de Streptococcus mutans. Posteriormente inseriu-se um disco de papel absorvente de $6 \mathrm{~mm}$ de diâmetro 
em cada placa de Petri com $15 \mu \mathrm{L}$ de cada fração do veneno $(2 \mathrm{mg} / \mathrm{mL})$, em separado, para observação quanto à presença ou ausência de halos de inibição do crescimento bacteriano em torno dos discos contendo as amostras.

Adicionalmente foram também avaliadas $\mathrm{PLA}_{2}$ de Bothrops jararacussu (BHTX-1) e de Bothrops moojeni, pertencentes ao estoque de toxinas do Centro de Biotecnologia.

No caso da $\mathrm{PLA}_{2}$ de $B$. jararacussu o ensaio foi feito também com a enzima na forma irradiada com 2 kGy.

Todos os ensaios foram realizados em triplicata e as amostras foram avaliadas na ausência ou presença de $2 \mathrm{~mL}$ de catalase (na concentração de 2 $\mathrm{mg} / \mathrm{mL}$ ) em 2 placas de Petri de $5 \mathrm{~cm}$ de diâmetro, preparadas com meio de cultivo sólido Mueller Hinton/Agar (15 mL).

\subsection{DETERMINAÇÃO DAS (MIC) DAS FRAÇÕES DOS VENENOS DE Bothrops moojeni E Bothrops jararacussu COM CAPACIDADE DE INIBIR O CRESCIMENTO.}

Para a determinação da MIC das frações dos venenos efetivos sobre as bactérias S. mutans estas foram incubadas (concentração de aproximadamente $2,63 \times 10^{6} \mathrm{CFU} / \mathrm{mL}^{-1}$ ) em placas de 96 poços com as frações dos venenos com ação inibitória, na concentração máxima de $4 \times 10^{-2}$ $\mu \mathrm{g}$, seguindo uma diluição seriada de fator 1:2. O ensaio foi realizado conforme descrito anteriormente no item 3.7. 


\section{RESULTADOS}

\subsection{BACTÉRIAS E CURVA DE CRESCIMENTO BACTERIANO.}

O cultivo da bactéria acompanhado pela leitura da densidade óptica pode ser visto no Gráfico 1 e resultou em uma curva LOG (crescimento) com o período de incubação de 26 horas e $\left(\mathrm{CFU} / \mathrm{mL}^{-1}\right)$ a concentração de aproximadamente $2,63 \times 10^{6}$ de $S$. mutans.

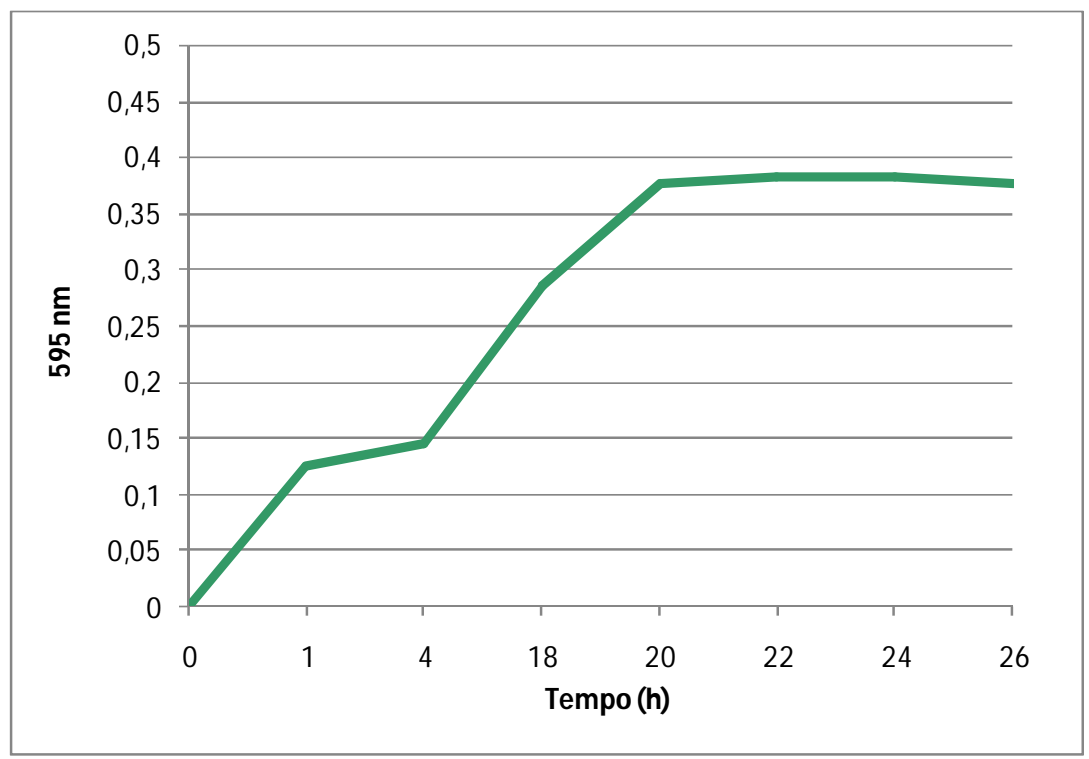

Gráfico 1: Curva de crescimento bacteriano no período de 26 horas em relação a densidade óptica $(\mathrm{nm})$.

\subsection{ANTIBIOGRAMA DOS VENENOS}

Após o plaqueamento do $S$. mutans e inserção dos discos de difusão com os diferentes tipos de venenos, foi observada a formação de halo de inibição do crescimento bacteriano na presença dos venenos de Bothrops jararacussu (2) e Bothrops moojeni (3) conforme mostrado na Figura 5. 

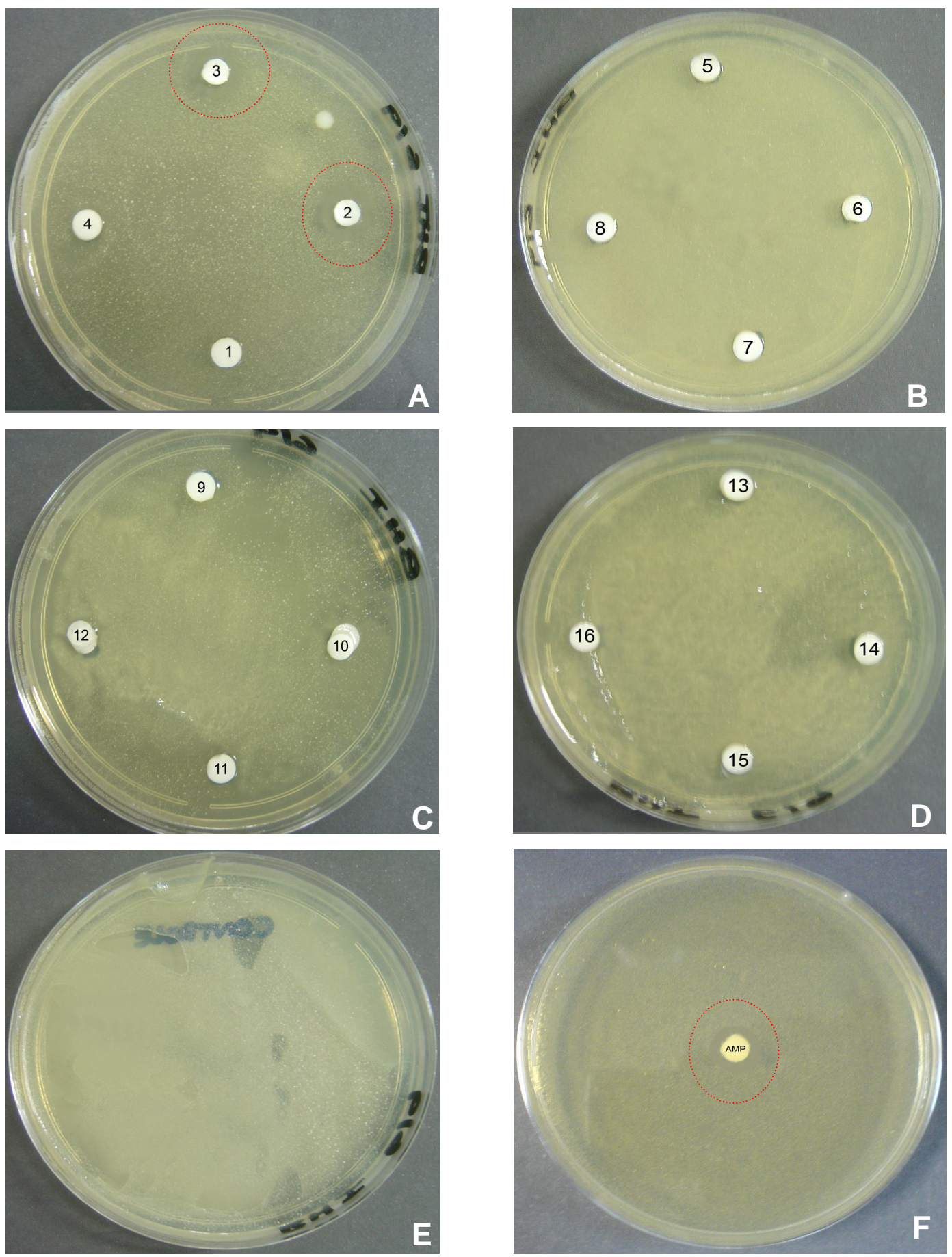

Figura 5 - Cultivo em meio sólido de BHI/Agar contendo os venenos ofídicos na forma nativa de: A - (1) Acanthophis antarcticus (2) Bothrops jararacussu (3) de Bothrops moojeni e (4) Agkistrodon bilineatus; B - (5) Hoplocephalus stephensi, (6) Naja melanoleuca, (7) Naja mossambica, (8) Notechis ater níger; C - (9) Notechis scutatus, (10) Oxyuranus microlepidotus, (11) Oxyuranus scutelatus, (12) Pseudechis australis; D - (13) Pseudechis colletti, (14) Pseudechis guttata, (15) Pseudechis porphyriacus, (16) Pseudonaja textills; E Controle; F - Controle com Ampicilina. 


\subsection{DETERMINAÇÃO DA PROPORÇÃO DE INIBIÇÃO DE CRESCIMENTO BACTERIANO DOS VENENOS COM CAPACIDADE DE INIBIR O CRESCIMENTO DE S. mutans}

A determinação da capacidade de inibir o crescimento do $S$. mutans foi feita incubando-se a bactéria com diferentes quantidades das frações dos venenos que se mostraram ativas, conforme descrito em MÉTODOS. Posteriormente, com tratamento estatístico dos dados obtidos, observou-se que utilizando-se $25 \times 10^{-6} \mu \mathrm{g}$ de veneno de Bothrops moojeni ou Bothrops jararacussu com tempo de incubação com S. mutans, de duas horas, foram obtidos os melhores resultados, conforme pode ser observado no Gráfico 2.

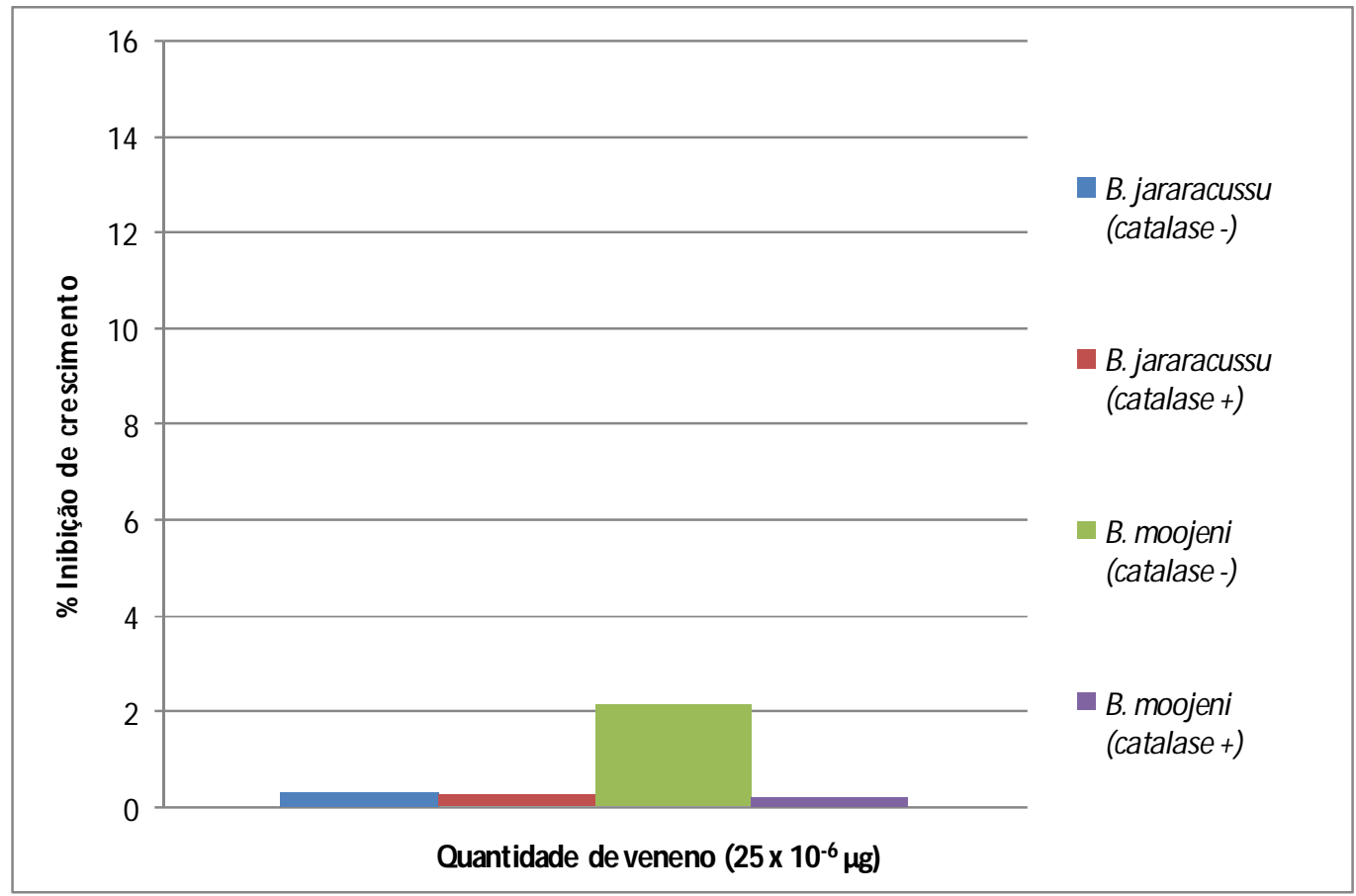

Gráfico 2: Porcentagem de inibição de crescimento bacteriano dos venenos de Bothrops jararacussu e Bothrops moojeni com e sem catalase em relação ao cultivo bacteriano. 
Conforme pode ser observado no Gráfico 2, a ausência da catalase no veneno total de $B$. moojeni, resulta em porcentagem de inibição do crescimento de $S$. mutans cerca de quatro vezes maior que na presença de catalase. $O$ veneno de $B$. jararacussu apresenta baixa porcentagem de inibição do S. mutans independentemente da presença de catalase.

\subsection{CROMATOGRAFIA POR FPLC}

A cromatografia dos venenos de Bothrops moojeni e de Bothrops jararacussu foi obtida conforme descrito em MÉTODOS e a absorvância das frações foi determinada em filtros de $280 \mathrm{~nm}$.

\section{Bothrops moojeni}

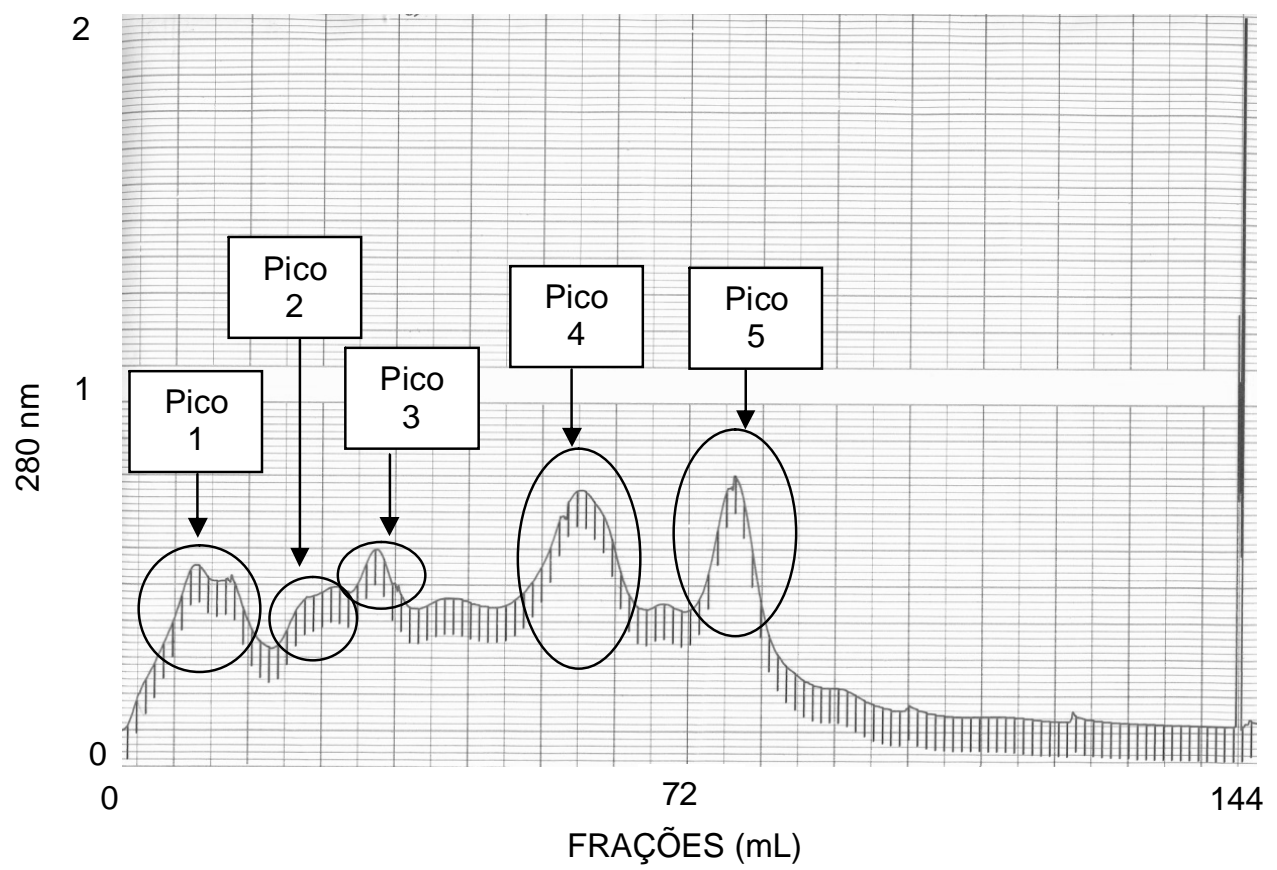

Gráfico 3 - Cromatografia de exclusão molecular do veneno de Bothrops moojeni em coluna Superdex 200 equilibrada em PBS pH 7.5. O fluxo de eluição foi de $1 \mathrm{~mL} / \mathrm{min}$. Pico 1 - frascos 18 a 23; Pico 2 - frascos 24 a 30; Pico 3 - frascos 36 a 47; Pico 4 frascos 66 a 72; Pico 5 - frascos 84 a 89 . 
No Gráfico 3 o perfil cromatográfico do veneno de B. moojeni mostra a presença de 5 diferentes frações que foram avaliadas, posteriormente, quanto ao poder de inibição do crescimento bacteriano.

\section{Bothrops jararacussu}

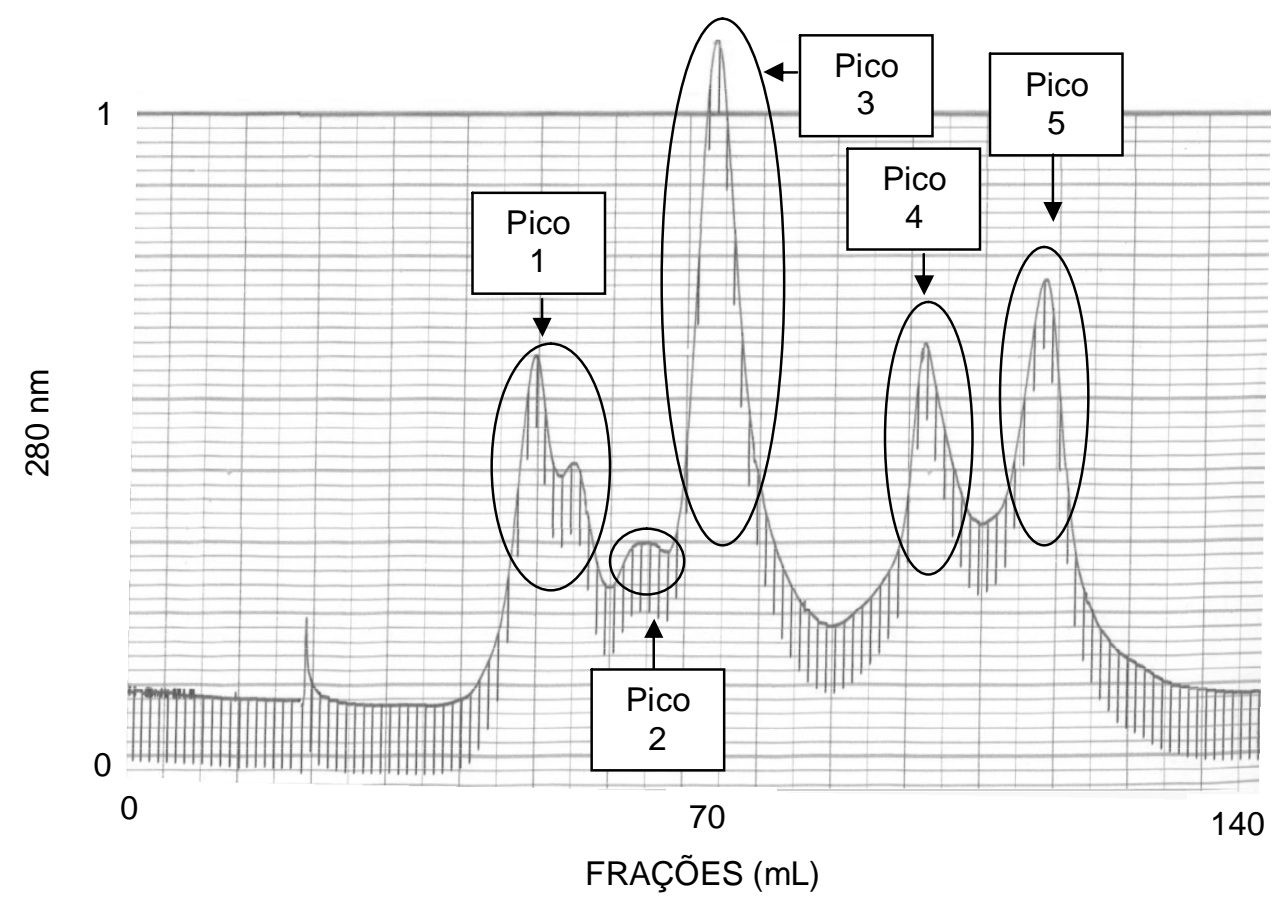

Gráfico 4 - Cromatografia de exclusão molecular do veneno de Bothrops jararacussu em coluna Superdex 200 equilibrada em PBS pH 7.5. O fluxo de eluição foi de $1 \mathrm{~mL} / \mathrm{min}$. Pico 1 - frascos 45 a 59; Pico 2 - frascos 60 a 65; Pico 3 - frascos 66 a 83; Pico 4 frascos 89 a 100; Pico 5 - frascos 102 a 114.

O perfil cromatográfico do veneno de $B$. jararacussu observado no Gráfico 4 mostra a presença de 5 diferentes frações que foram avaliadas, posteriormente, quanto ao poder de inibição do crescimento bacteriano. 


\section{5. $\quad$ ANTIBIOGRAMA DAS FRAÇÕES DOS VENENOS DE Bothrops} moojeni E Bothrops jararacussu.

Após o plaqueamento das bactérias foi feita a inserção dos discos de difusão com $20 \mu \mathrm{L}$ das frações dos venenos de B. moojeni, na concentração de $2 \mathrm{mg} / \mathrm{mL}$. A presença dos halos pode ser constatada na Figura 6 . 


\section{Bothrops moojeni}
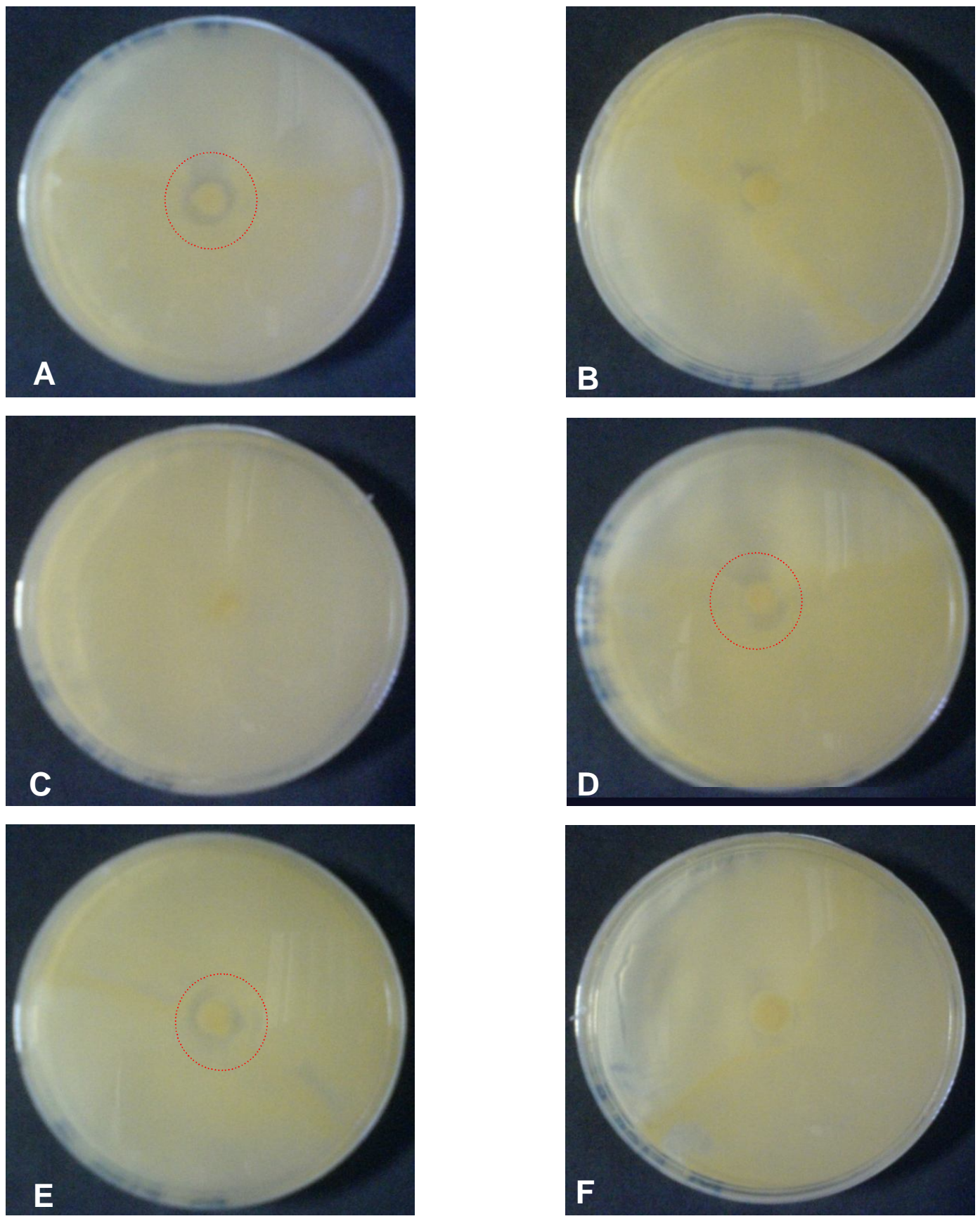

Figura 6 - Placa de Petri com meio sólido de BHI/Agar contendo $S$. mutans as frações do veneno de Bothrops moojeni onde: A - Pico 1; B - Pico 2; C - Pico 3; D - Pico 4; E - Pico 5 e F - Controle. 
Como pode ser observado Figura 6 (B. moojenı) apenas as frações correspondentes aos picos 1, 4 e 5 foram capazes de inibir o crescimento de S. mutans.

Após o plaqueamento das bactérias foi feita a inserção dos discos de difusão com $20 \mu \mathrm{L}$ das frações dos venenos de $B$. jararacussu, na concentração de $2 \mathrm{mg} / \mathrm{mL}$. A presença dos halos pode ser constatada na Figura 7. 


\section{Bothrops jararacussu}
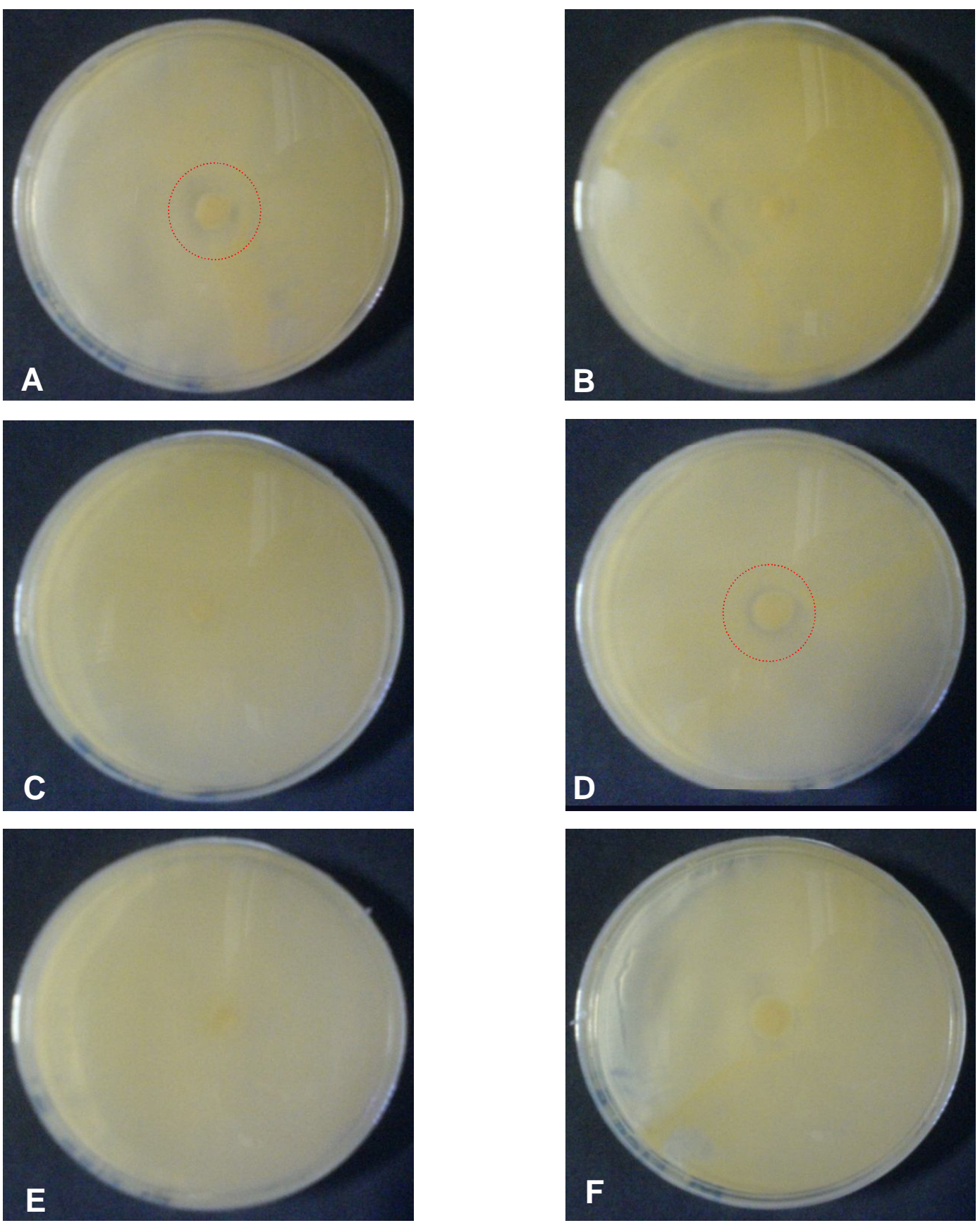

Figura 7 - Placa de Petri com meio sólido de BHI/Agar contendo $S$. mutans e as frações do veneno de Bothrops jararacussu onde: A - Pico 1; B - Pico 2; C - Pico 3; D - Pico 4 e E Pico 5 e F - Controle. 
Na Figura 7 (B. jararacussu) apenas as frações correspondentes aos picos 1 e 4 foram capazes de inibir o crescimento de $S$. mutans.

Adicionalmente foram avaliadas frações de $\mathrm{PLA}_{2}$ oriundas dos venenos de Bothrops moojeni, Bothrops jararacussu na sua forma nativa (Bothrops moojeni e Bothrops jararacussu) e irradiada (Bothrops jararacussu) na ausência e presença de catalase conforme mostrado nas Figuras 8 e 9.

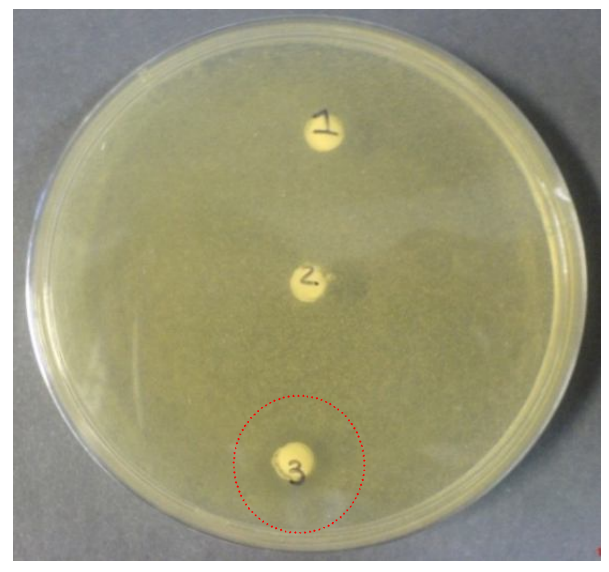

Figura 8 - Placa de Petri com meio sólido de BHI/Agar contendo $S$. mutans e as frações de $\mathrm{PLA}_{2}$ na forma nativa (1) e irradiada (2) de $B$. jararacussu e na forma nativa (3) de $B$. moojeni na ausência de catalase.

Conforme pode ser observado na Figura 8 a PLA 2 de $B$. jararacussu (BTHX-1) nativa (1) e BTHX-1 irradiada (2) não foram capazes de inibir o crescimento de S. mutans. Por outro lado, a $\mathrm{PLA}_{2}$ de B. moojeni (BMTX) apresentou discreta inibição do crescimento da bactéria.

Foram realizados testes com a presença de catalase, para investigar a possibilidade de a ação antibacteriana ser causada pela presença de $\mathrm{H}_{2} \mathrm{O}_{2}$, decorrente da reação química da deaminação oxidativa da LAO. 


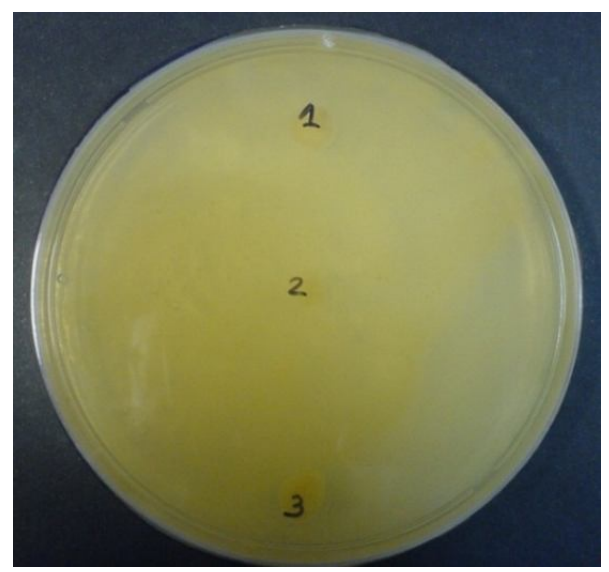

Figura 9 - Placa de Petri com meio sólido de BHI/Agar contendo $S$. mutans e as frações de $\mathrm{PLA}_{2}$ na forma nativa (1) e irradiada (2) de $B$. jararacussu e na forma nativa (3) de $B$. moojeni na presença de catalase.

Conforme pode ser observado na Figura 9, na presença de catalase, a $\mathrm{PLA}_{2}$ de B. jararacussu (BTHX-1) nativa (1), BTHX-1 irradiada (2) e B. moojeni (BMTX) não foram capazes de inibir o crescimento de S. mutans.

\subsection{DETERMINAÇÃO DA PROPORÇÃO DE INIBIÇÃO DE CRESCIMENTO BACTERIANO DAS FRAÇÕES EFETIVAS DOS VENENOS DE Bothrops moojeni E Bothrops jararacussu}

A determinação da capacidade de inibir o crescimento do $S$. mutans foi feita incubando-se a bactéria com diferentes quantidades das frações dos venenos que se mostraram ativa, conforme descrito em MÉTODOS. Posteriormente, com tratamento estatístico dos dados obtidos, observou-se que utilizando-se $25 \mu \mathrm{g}$ de veneno de Bothrops moojeni ou Bothrops jararacussu incubados por duas horas com o S. mutans, foram obtidos os melhores resultados, 
Relacionando os valores bem como a proporção em relação ao meio de cultivo com bactérias, foram gerados gráficos observados abaixo:

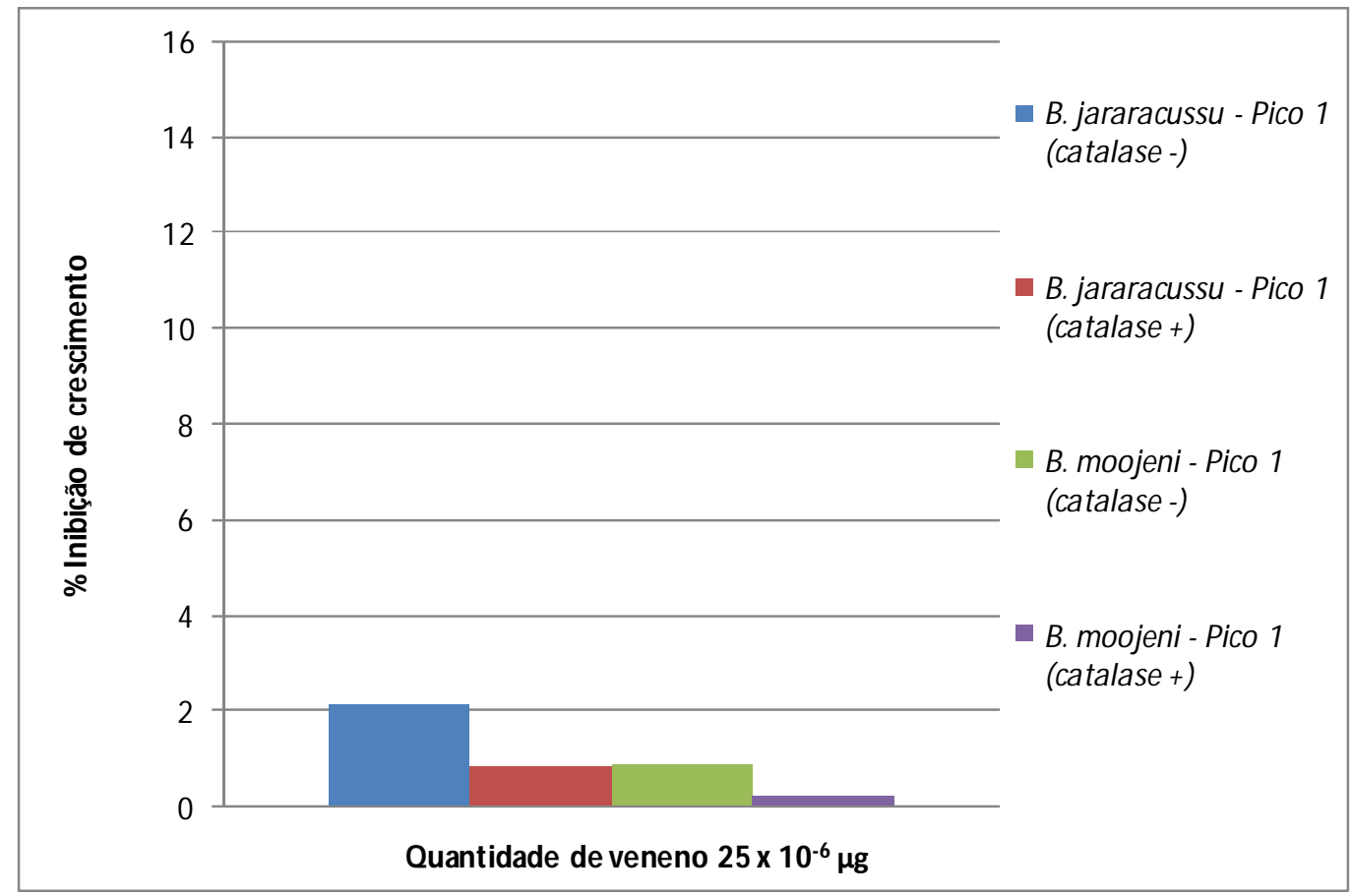

Gráfico 5 - Porcentagem de inibição de crescimento bacteriano do Pico 1 de Bothrops jararacussu e Bothrops moojeni com e sem catalase em relação ao cultivo bacteriano.

Conforme pode ser observado no Gráfico 5, o Pico 1 do veneno total de B. jararacussu, na ausência de catalase inibe cerca de duas vezes mais o crescimento de $\mathrm{S}$. mutans do que na presença de catalase. $\mathrm{O}$ mesmo se observa para o Pico 1 do veneno de $B$. moojeni. O Pico 1 do veneno de $B$. jararacussu, com catalase, apresenta a mesma porcentagem de inibição de crescimento do Pico 1 de B. moojeni, sem catalase e o Pico 1 de B. moojeni com catalase apresenta porcentagem de inibição três vezes menor que os Pico 1 de B. moojeni e de B. jararacussu sem catalase. 


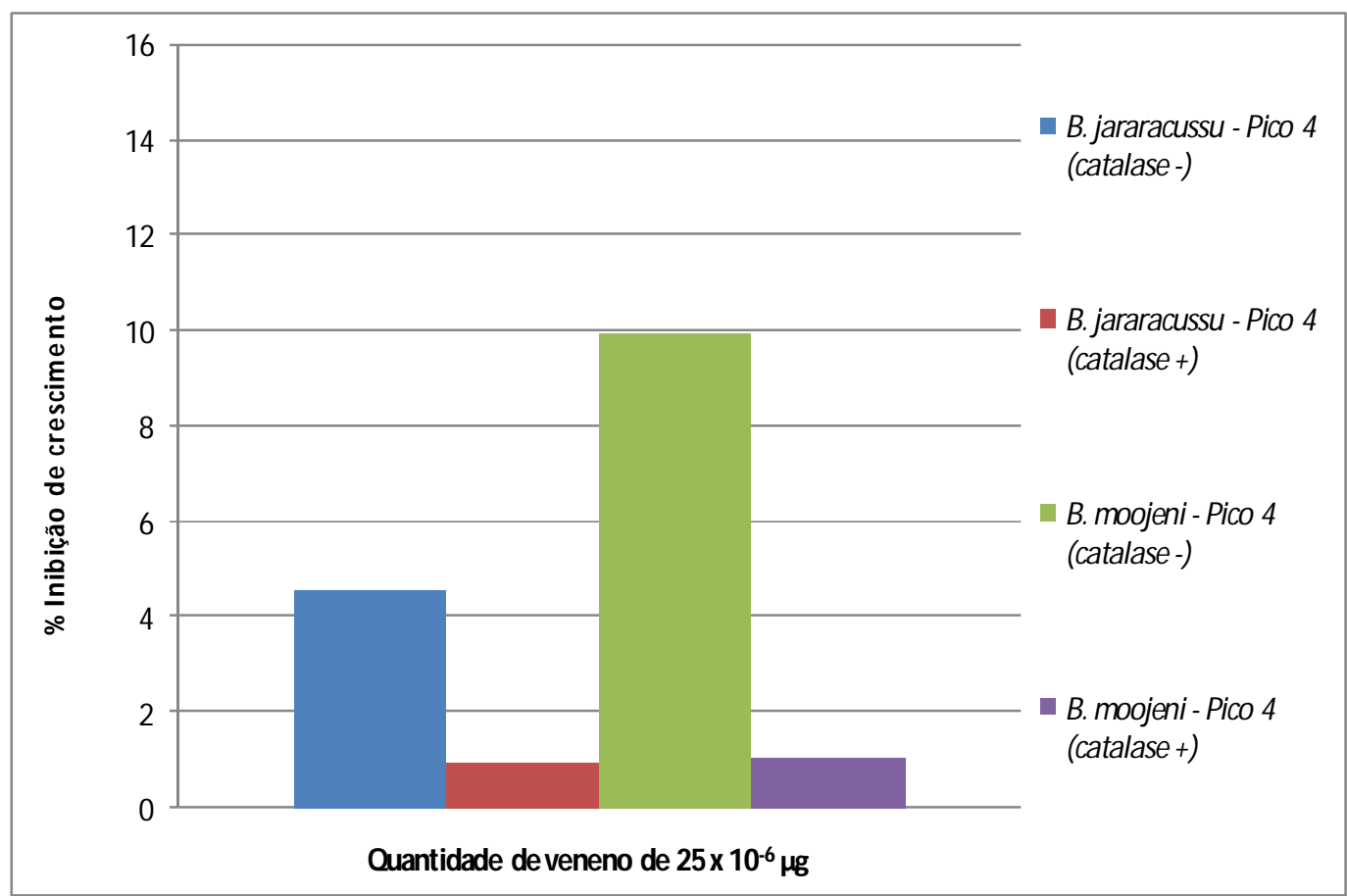

Gráfico 6 - Porcentagem de inibição de crescimento bacteriano do Pico 4 de Bothrops jararacussu e Bothrops moojeni com e sem catalase em relação ao cultivo bacteriano.

Conforme pode ser observado no Gráfico 6, o Pico 4 do veneno total de B. jararacussu, na ausência de catalase inibe cerca de quatro vezes mais o crescimento de S. mutans do que na presença de catalase. O Pico 4 do veneno de B. moojeni, na ausência de catalase, apresentou uma porcentagem de inibição de crescimento de $S$. mutans cerca de dez vezes maior que com catalase. O Pico 4 de B. jararacussu, com catalase apresentou a mesma porcentagem de inibição do Pico 4 de B. moojeni com catalase. 


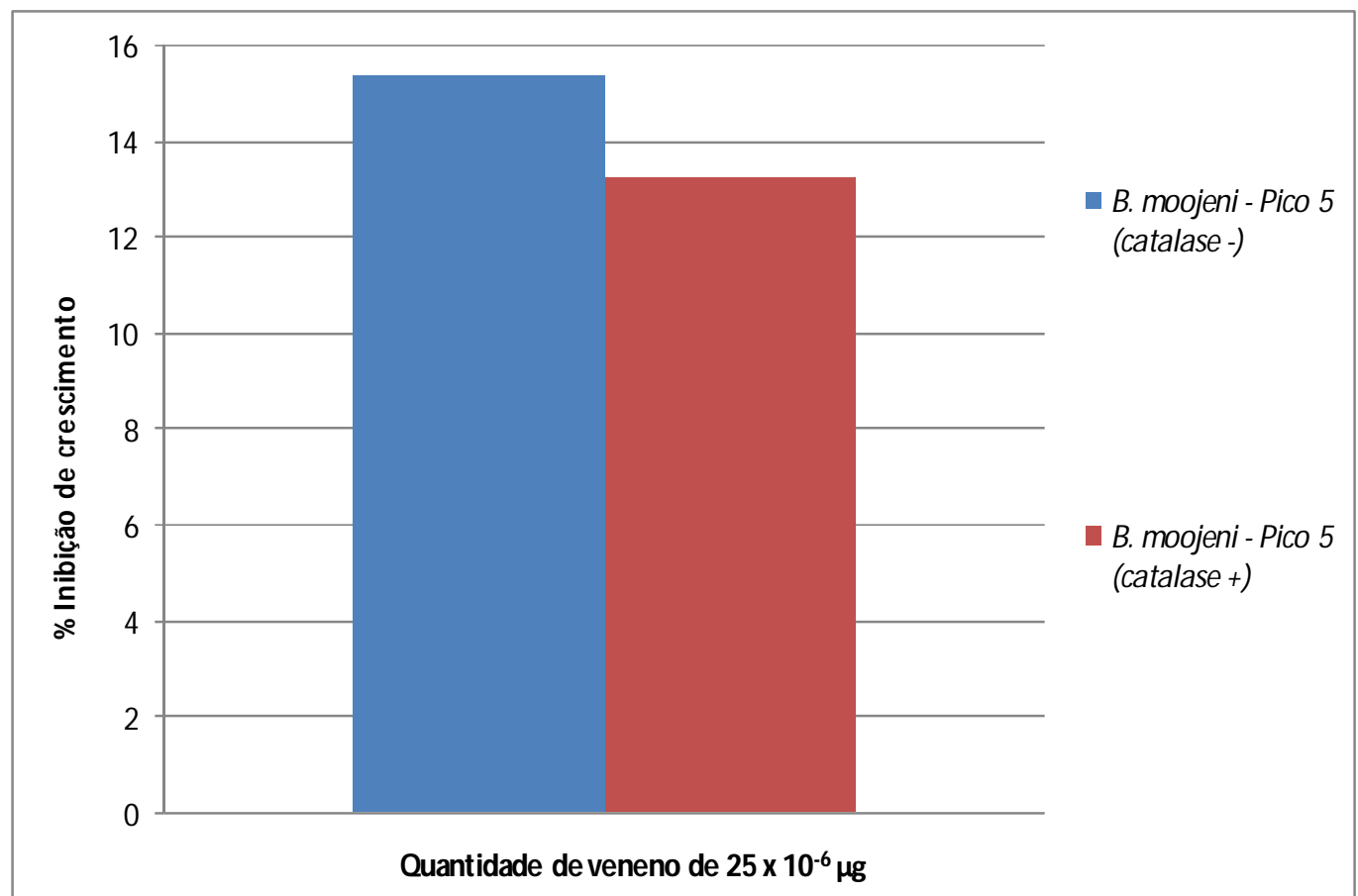

Gráfico 7 - Porcentagem de inibição de crescimento bacteriano do Pico 5 de Bothrops moojeni com e sem catalase em relação ao cultivo bacteriano.

Conforme pode ser observado no Gráfico 7, o Pico 5 do veneno total de B. moojeni, alta porcentagem de inibição de crescimento de $S$. mutans. Na ausência de catalase, a porcentagem de inibição de crescimento foi pouco maior que $0,5 \%$ quando comparado ao mesmo pico na presença de catalase. 


\section{DISCUSSÃO}

A cárie dental é a doença infecciosa de maior prevalência e de maior incidência na espécie humana, constituindo-se em relevante problema de Saúde Pública e individual na maioria dos países.

Esta doença que acomete a grande maioria da população age de forma simplificada, pela interação única e exclusiva de três fatores (Tríade de Keyes).

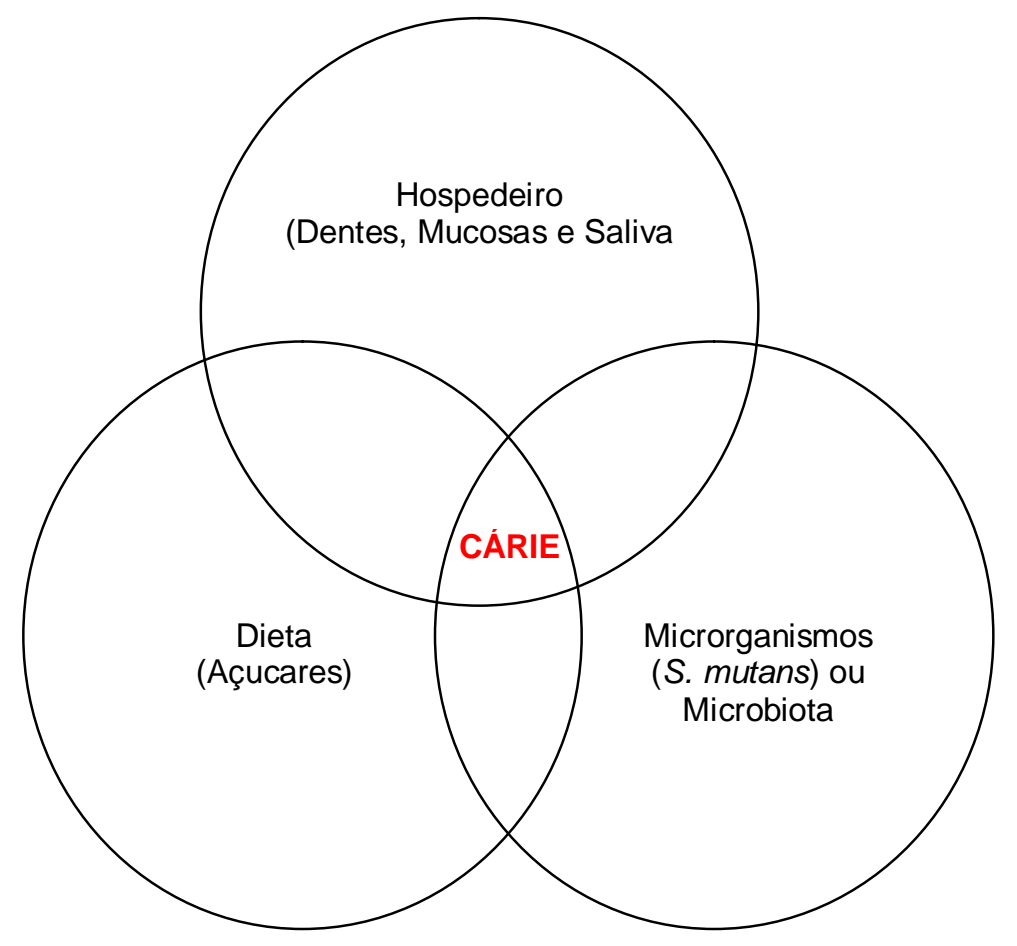

A cárie dental promove lesões e, em geral, é criada pela ação progressiva da desmineralização do esmalte dentário em virtude da liberação de toxinas pelo Streptococcus mutans.

A interação entre os componentes que integram esta Tríade por determinado tempo promove as condições para a doença se manifestar. Assim, a preocupação em não deixar estes fatores interagirem e causarem a lesão passa, obrigatoriamente, pelo estudo de controle do Streptococcus 
mutans na medida em que representa uma necessidade de reforçar mudanças nos programas de Saúde Pública, com possibilidade de potencializar o impacto dos índices epidemiológicos de saúde bucal da população brasileira.

Um dos marcos mais importantes da história da Odontologia foi a descoberta das propriedades anticariogênicas dos fluoretos, pois possibilitou o desenvolvimento de medidas eficazes de prevenção e controle da cárie dentária (OLIVEIRA \& MILBOURNE, 2001). O maior responsável pelo declínio da cárie dentária nas últimas décadas foi o flúor, aplicado à população através da água fluoretada, esquema terapêutico coadjuvado por outras técnicas de aplicação como os dentifrícios fluoretados (SCABAR et al., 2004)

Porém, o uso de fluoretos, sistêmico ou tópico, no tratamento ou prevenção de cárie dentária pode resultar na ingestão e absorção do mesmo para a circulação sanguínea. Assim, a mineralização dos dentes em formação pode ser afetada, resultando em fluorose dentária (FAJERSKOV et al., 1990).

A diferença entre uma substância venenosa e uma substância farmacêutica ou mesmo nutricional é a dose administrada ou acumulada no corpo mas, em geral, um veneno é mortal em determinada dose e sem qualquer função terapêutica. Dois exemplos de substâncias venenosas são o flúor e o iodo, ambos são extremamente venenosos, mas têm aplicações terapêuticas em mínimas doses, sendo o iodo indispensável e o flúor um bom fármaco contras as cáries. 
Os venenos podem ser de origem:

- Mineral (arsênico ou mercúrio, por exemplo);

- Vegetal (a cicuta ou algumas plantas venenosas, por exemplo; as plantas medicinais, como a Atropa belladona, contêm substâncias tóxicas que são venenos em determinadas quantidades);

- Animal (peçonha de serpentes, abelhas, por exemplo);

- Artificial (muitas das substâncias sintetizadas pelo ser humano na indústria, por exemplo, como o ácido sulfúrico, ou o monóxido de carbono do escapamento dos automóveis).

O veneno é definido como qualquer tipo de substância tóxica, seja ela sólida, líquida ou gasosa, que possa produzir qualquer tipo de enfermidade, lesão, ou alterar as funções do organismo ao entrar em contato com um ser vivo, por reação química com as moléculas do organismo.

Os efeitos antibacterianos de venenos ofídicos já foram observados por alguns pesquisadores como GLACER (1948) e SKARNES (1970).

No presente trabalho foram avaliados venenos animais, especificamente de serpentes, quanto ao seu poder de inibição do crescimento de Streptococcus mutans, principal agente etiológico da cárie dentária.

Um antibiograma é um ensaio que mede a susceptibilidade/resistência de uma bactéria a um ou mais agentes antimicrobianos. Este ensaio permite tanto a análise do espectro de sensibilidade/resistência de uma bactéria às drogas quanto à determinação da concentração mínima inibitória.

O Ágar de Mueller Hinton é recomendado pelo U.S. Food and Drug Administration (FDA) e pela Organização Mundial da Saúde (OMS) para o teste de sensibilidade/resistência aos antibióticos de bactérias Gram-Positivas 
e Gram-Negativas, aeróbicas ou anaeróbicas facultativas, comumente encontradas em alimentos e espécimes clínicos. O teste, denominado antibiograma, é feito utilizando-se discos de difusão de antibióticos depositados sobre a superfície do meio onde se aplicou, por espalhamento, uma amostra de uma cultura bacteriana previamente crescida em meio líquido.

A concentração inibitória mínima (MIC) é a mínima concentração de um agente antimicrobiano requerida para inibir, in vitro, o crescimento de determinado microrganismo (ESTRELA, 2000; KOO et al. 2000; DUARTE et al. 2003). A MIC deve ser única para uma mesma substância, mas pode variar dependendo do microrganismo analisado.

A MIC e a Concentração Bactericida Mínima (MBC) são indicadores da potência de um antibiótico, mas a presença de efeito persistente (pósantibiótico) e a taxa de eliminação concentração-dependente são indicativos melhores da capacidade bactericida dos fármacos. Assim, antibióticos que tenham atividade bactericida concentração-dependente vão conseguir alcançar magnitude de efeito bactericida com o aumento das concentrações acima da MIC até um ponto máximo, em geral em torno de cinco ou dez vezes (SELIGMAN, 2004).

Venenos de duas famílias Viperidae e Elapidae foram incubados com o Streptococcus mutans em placas de Petri com meio apropriado e foi feita a avaliação quanto ao poder de inibição do crescimento da bactéria.

A observação das placas de antibiograma mostrou que apenas os venenos das serpentes $B$. moojeni e $B$. jararacussu apresentaram halo de inibição de crescimento do $S$. mutans corroborando os resultados de STILES e colaboradores (1991) que, estudando 30 tipos de venenos de diferentes 
espécies de serpentes, das famílias Elapidae e Viperidae, contra bactérias gram-positivas e gram-negativas, observaram que os halos de inibição eram maiores para S. aureus (Gram-Positiva) na família das serpentes Viperidae quando comparados aos produzidos pelos venenos das serpentes Elapidae.

Por outro lado, nossos resultados mostram que os venenos das serpentes Naja mossambica, Notechis scutatus scutatus, Acanthophis antarcticus e Pseudechis australis não apresentaram halo de inibição para a bactéria gram-positiva $S$. mutans, divergindo dos relatos apresentados por STILES e colaboradores (1991) que observaram poder de inibição para todas as serpentes citadas acima, quando incubados com S. aureus.

Esta diferença de resultados talvez possa ser explicada por se tratar de bactérias diferentes, embora os mecanismos de defesa das bactérias GramPositivas são idênticos. Outros fatores que podem concorrer para a divergência dos resultados são a origem e a forma de armazenamento ou solubilização dos venenos.

PERUMAL SAMY e colaboradores (2007) estudaram 14 venenos de serpentes da família Elapidae e 8 da família Viperidae, bem como venenos de abelha e escorpião, utilizando protocolos semelhantes aos de STILES e colaboradores (1991), para as bactérias $S$. aureus (gram-positiva), $P$. aeruginosa, E. coli, P. mirabilis, P. vulgaris e E. aererogenes (gramnegativas). $O$ grupo de pesquisadores incubou a bactéria gram-positiva $S$. aureus com os 6 venenos da família Elapidae, também utilizados em nossos experimentos: Acanthophis antarcticus, Pseudechis australis, Pseudechis colletti, Pseudechis guttata, Pseudechis porphyriacus e Pseudonaja textills. 
Diferentemente dos resultados apresentados neste trabalho, foram observados halos de inibição para estes venenos.

Adicionalmente, uma provável explicação para as diferenças entre os resultados encontrados, para as cepas de bactérias Gram-Positivas, pode ser a variabilidade na composição e concentração do veneno que, em uma dada espécie, diferem em função de fatores como idade, sexo e origem geográfica (CHIPPAUX et. al., 1991).

Conforme relatos de MEIER (1990) os venenos são misturas complexas, constituídas principalmente por proteínas, dentre as quais destacamos os L-aminoácidos (LAO).

A L-aminoácido oxidase é uma flavoenzima que catalisa a deaminação oxidativa do substrato L-aminoácido em um cetoácido com produção de amônia e peróxido de hidrogênio $\left(\mathrm{H}_{2} \mathrm{O}_{2}\right)$. A LAO é a única oxidase FADdependente presente nos venenos de serpentes e sua toxicidade possivelmente envolva a geração de peróxido de hidrogênio formado por meio da re-oxidação da redução transiente do co-fator flavano pela molécula de oxigênio.

O $\mathrm{H}_{2} \mathrm{O}_{2}$ tem ação bactericida conhecida (RUTALA, 1990), agindo diretamente nas membranas lipídicas das bactérias. $O$ uso da enzima catalase, decompõe $\circ \mathrm{H}_{2} \mathrm{O}_{2}$ em água e oxigênio, anulando sua ação bactericida, pois tem o mais alto número de turnover (kcat) conhecido em enzimas, onde uma molécula de catalase pode catalisar a decomposição de até 40. 000.000 de moléculas de $\mathrm{H}_{2} \mathrm{O}_{2}$ por segundo (NELSON \& COX, 2005) tornando-a numa enzima importante para a desintoxicação desta substância. 
Nossos resultados mostraram que os venenos efetivos, oriundos das serpentes de B. moojeni e B. jararaca, apresentaram comportamentos diferentes vinculados à presença da catalase. Observou-se que a ausência da catalase no veneno total de $B$. moojeni inibe cerca de quatro vezes mais o crescimento de S. mutans. Por outro lado, o veneno de B. jararacussu apresenta baixa porcentagem de inibição do $S$. mutans independentemente da presença ou ausência da catalase.

Estudos desenvolvidos por TEMPONE e colaboradores (2001), mostraram que o veneno da serpente B. moojeni tem atividade antiparasitária in vitro para Leishmania spp. Segundo os pesquisadores a atividade de inibição de crescimento se deve à ação da enzima L-aminoácido oxidase (LAO), presente no veneno, que está diretamente relacionada à formação de peróxido de hidrogênio. Tal afirmação se deve aos resultados apresentados quando os ensaios de inibição foram feitos na presença de catalase, que ao inibir a formação do peróxido, aboliu a capacidade de inibir o crescimento do protozoário, corroborando nossos resultados com S. mutans.

Segundo PERUMAL SAMY e colaboradores (2007) a degradação enzimática dos fosfolipídios com a ação na membrana pode ser um dos importantes fatores nas propriedades bactericidas dos venenos animais, o que implicaria em uma ação sinérgica entre os peptídeos antimicrobianos e as enzimas dos venenos.

A avaliação das frações dos venenos efetivos quanto à capacidade de inibição do crescimento de $S$. mutans mostrou que das seis frações isoladas do veneno de B. moojeni, apenas as frações correspondentes aos Picos 1, $4 \mathrm{e}$ 5 foram capazes de inibir o crescimento de $S$. mutans. 
Das frações isoladas do veneno da serpente B. jararacussu, apenas aquelas correspondentes aos Picos 1 e 4 foram capazes de inibir o crescimento de $S$. mutans.

A fração correspondente ao Pico 1 do veneno total de B. moojeni, na ausência de catalase, inibe cerca de duas vezes mais a porcentagem de crescimento de $S$. mutans do que na presença de catalase.

A fração correspondente ao Pico 1 do veneno total de B. jararacussu, na ausência de catalase, também inibe cerca de duas vezes mais a porcentagem de crescimento de $S$. mutans do que na presença de catalase. Cabe ressaltar, entretanto que a porcentagem de inibição 0 veneno da serpente $B$. jararacussu, sem catalase, é duas vezes maior que o apresentado pelo veneno da serpente $B$. moojeni, sem catalase.

A fração correspondente ao Pico 4 do veneno de $B$ moojeni, na ausência de catalase, apresentou uma porcentagem de inibição de crescimento de $S$. mutans cerca de dez vezes maior que com catalase e foi a segunda fração com maior porcentagem de inibição de crescimento dentre as avaliadas.

A fração correspondente ao Pico 4 do veneno total de B. jararacussu , na ausência de catalase, inibiu cerca de quatro vezes mais o crescimento de S. mutans do que na presença de catalase.

Nota-se que a fração correspondente ao Pico 4 de B. moojeni apresenta uma porcentagem de inibição de crescimento de $\mathrm{S}$. mutans mais que duas vezes maior que a apresentada pela fração correspondente ao Pico 4 do veneno de $B$. jararacussu. 
A fração referente ao Pico 4 de $B$. jararacussu, com catalase, apresentou a mesma porcentagem de inibição do Pico 4 de B. moojeni com catalase. Entretanto, a fração correspondente ao Pico 1 com catalase do veneno de $B$. jararacussu apresentou porcentagem de inibição três vezes maior que a fração correspondente ao Pico 1, com catalase, do veneno de $B$. moojeni.

A fração correspondente ao Pico 5 do veneno total de $B$ moojeni, independentemente da presença da catalase apresentou a maior porcentagem de inibição do crescimento de S. mutans. Mesmo na presença de catalase, esta porcentagem de inibição diminuiu apenas $0,5 \%$, sugerindo que os componentes desta fração são pouco afetados pela catalase.

Nossos estudos realizados com a $\mathrm{PLA}_{2}$ do veneno de Bothrops moojeni mostraram sua capacidade de inibir o crescimento da bactéria $S$. mutans. Entretanto tal efeito era anulado na presença de catalase. Este resultado merece uma avaliação mais acurada, pois a catalase não tem ação direta na reação química entre a degradação dos fosfolipídios e teoricamente somente a LAO libera $\mathrm{H}_{2} \mathrm{O}_{2}$ no sistema.

Por outro lado, utilizando-se $\mathrm{PLA}_{2}$ do veneno efetivo de Bothrops jararacussu (BTHX-1) não se observou qualquer inibição do crescimento da bactéria $S$. mutans. Decidimos tentar usar a radiação gama para avaliar uma possível alteração na atividade desta enzima, contudo, os resultados obtidos mostraram que a energia depositada não foi capaz de alterar esta PLA $A_{2}$, na presença ou na ausência de catalase. 
Estes resultados, de certa maneira, chegam a ser surpreendentes, uma vez que a ação direta da $P L A_{2}$ dos venenos ofídicos está ligada à degradação dos fosfolipídios contidos na parede celular das bactérias.

Cabe ressaltar ainda que a irradiação de moléculas protéicas em solução leva à formação dos produtos da radiólise da água, dentre eles $\circ \mathrm{H}_{2} \mathrm{O}_{2}$ que poderia interagir com a catalase e alterar os resultados.

Embora o veneno total de $B$. jararacussu tenha apresentado menor capacidade de inibição de crescimento que o veneno da serpente B. moojeni, quando submetido à cromatografia, algumas frações apresentaram capacidade de inibição de $S$. mutans muito maior que aquela apresentada pelo veneno total, sugerindo que alguns componentes presentes no veneno inibem esta atividade bacteriostática.

De modo geral, a incubação dos venenos com a bactéria S. mutans, na ausência de catalase, apresentou menor turbidez $\left(A_{595}\right)$, confirmando a participação da $\mathrm{H}_{2} \mathrm{O}_{2}$ na inibição do crescimento bacteriano, conforme já havia sido relatado por TEMPONE e colaboradores (1991). A influência da catalase na inibição do crescimento bacteriano dependente da concentração do veneno, bem como do tempo de incubação.

Assim, apesar de ainda não totalmente conclusivos, os ensaios realizados permitem afirmar que venenos de serpentes são ferramentas importantes na inibição do crescimento de patógenos e que, portanto, são candidatos a novos fármacos, especificamente aqueles a serem desenvolvidos para a terapêutica das doenças cariogênicas. 


\section{CONCLUSÕES}

- O antibiograma foi eficiente na seleção de venenos com capacidade de inibir o crescimento de $S$. mutans.

- Os venenos das serpentes do gênero Bothrops: $B$. moojeni e $B$.

jararacussu foram os únicos, dentre os avaliados, que apresentaram capacidade de inibição do crescimento de $S$. mutans.

- A presença da catalase inibe a capacidade de inibição do crescimento dos venenos sobre o $S$. mutans 


\section{REFERÊNCIAS BIBLIOGRÁFICAS}

AJDIC, D.; MCSHAN, W.M.; MCLAUGHLIN, R.E.; SAVIC, G.; CHANG, J.; CARSON, M.B; PRIMEAUX, C.; TIAN, R.; KENTON, S.; JIA, H.; LIN , S.; QIAN, Y.; LI, S.; ZHU, H.; NAJAR, F.; LAI, H.; WHITE, J.; ROE, B.A.; FERRETTI, J.J. Genome sequence of Streptococcus mutans UA159, a cariogenic dental pathogen. PNAS, v. 99, n. 22, p. 14439, 2002.

BAPTISTA, J.A. Aspectos da resposta imune frente a antígenos protéicos irradiados com ${ }^{60} \mathrm{Co}$. Dissertação apresentada ao Programa de Mestrado em Ciências (área de concentração: Tecnologia Nuclear - Aplicações), da Autarquia associada a Universidade de São Paulo, IPEN-CNEN/SP, 2004.

BARBOSA, P.S.F.; MARTINS, A.M.C.; HAVT, A.; TOYAMA, D.O.; EVANGELISTA, J.S.M.A.; FERREIRA, D.P.P.; JOAZEIRO, P.P.; BERIAM, L.O.S.; TOYAMA, M.H.; FONTELES, M.C.; MONTEIRO, H.S.A. Renal and antibacterial effects induced by miotoxin I and II isolated from Bothrops jararacussu venom. Toxicon. v. 26, p. 376-386, 2005.

BERKOWITZ, R.J.; JORDAN, H.V.; WHITE, G. The early establishment of Streptococcus mutans in the mouths of infants. Arch. Oral Biol. v. 20, n. 3, p. 171-174, Mar., 1975.

BARRAVIEIRA, B. \& FERREIRA JUNIOR, R.S. Acidentes por animais peçonhentos. CEVAP-UNESP, $1^{\circ}$ edição, 110p., 2007. 
BRADFORD, M.M. A rapid and sensitive method for quantification of microgram quantities of protein utilizing the principle of protein dye binding. Anal Biochem. v. 7, n. 7, p. 2248-54, Maio, 1976.

CARDI, B.A.; NASCIMENTO, N.; ANDRADE JUNIOR, H.F. Irradiation of Crotalus durissus terrificus crotoxin with ${ }^{60} \mathrm{Co}$ gamma rays induces its uptakes by macrophages. Int. J. Radiat. Biol., v. 73, n. 5, p. 557-564, 1997.

CARLSSON, J.; GRAHNÉN, H.; JONSSON, G. Lactobacilli and Streptococci in the mouth of children. Caries Res. n. 3, p. 333-339, 1975.

CHIA, J.S.; LIN, Y.L.; LIEN, H.T.; CHEN, J.Y. Platelet aggregation induced by serotype polysaccharides from Streptococcus mutans. Infect Immun. v. 72, n.5, p. 2605-17, Maio, 2004.

CHIPPAUX, J.P; WILLIAM, V.; WHITE, J. Snake venom variability: methods of study, results and interpretation. Toxicon, v. 29, p. 1279-1303, 1991.

CHO, W.; MARKOWITZ, M.A. \& KÉZDY, F.J. A New Class of Phospholipase A2 Substrates: Kinetics of the Phospholipase A2 Catalyzed Hydrolysis of 3 (Acyloxy)-4-nitrobenzoic Acids. J.Am.Chem.Soc., v. 110, p. 5166-5171, 1988. 
Coordenação de Saúde Bucal da SAS/MS.

http://portalweb02.saude.gov.br/portal/aplicacoes/noticias/noticias detalhe.cfm

?co seq noticia=5512, acessado no dia 23 de Março de 2006.

DUARTE, S.; KOO, H.; BOWEN, W.H.; HAYACIBARA, M.F.; CURY, J.A.; IKEGAKI, M.; ROSALEN, P.L. Effect of a Novel Type Propolis and Its Chemical Fraction on Glucosyltransferases and on Growth and Adherence of Mutans Streptococci. Biol. Pharm. Bull. v. 26, n. 4, p. 527-531, 2003.

DURACK, D.T. Prevention of infective endocarditis. N. Engl. J. Med. v. 332, p. 3844, 1995.

EDWARDSSON, S. \& MEJÁRE, G. Streptococcus milleri (Guthof) and Streptococcus mutans in the mouth of infants before and after tooth eruption. Arch Oral Biol. n. 23, p. 811-814, 1978.

ESTRELA, C.R.A. Eficácia antimicrobiana de soluções irrigadoras de canais radiculares. Dissertação apresentada ao Programa de Mestrado em Medicina Tropical (área de concentração: Microbiologia), da Universidade Federal de Goiás, 2000.

FEJERSKOV, O.; MANJI, F.; BALEUM, V. The nature and mechanisms of dental fluorosis in man. J Dent Res, n.69, p. 692-700, 1990. 
FITZGERALD, R.J. \& KEYS, P.H. Demonstration of the etiologic role of streptococci in experimental caries in hamster. J Am Dent Ass. n. 61, p. 919, 1960.

FITZGERALD, R.J.; JORDAN, H.V., ARCHARD, H.O. Dental caries in gnotobiotic rats infected with a variety of Lactobacillus acidophilus. Arch Oral Biol. $\mathrm{n}$. 11, p. 473, Maio 1966.

FRY, B.G. Structure-function properties of venom components from Australian elapids. Toxicon. v. 37, p. 11-32, 1999.

FOX, A. Bacteriology - Chapter twelve - Streptococci. In: Microbiology and Immunology On-line, Hunt, R.C. editor. http://pathmicro.med.sc.edu/folder name/chapter name.htm University of South Carolina School of Medicine, acessado em Julho de 2005.

GIBBONS, R.J. \& VAN HOUTE, J. Dental caries. Annual Review of Medicine. n. 26, p. 121-136, 1975a.

GLASER, H.S.R. Bacterial activity of Crotalus venom in vitro. Copeia n. 4, p. 245$247,1940$. 
GOMES, P.R.; COSTA, S.C.; CYPRIANO, S.; DE SOUSA, M.D.A.L. Dental caries in Paulinia, Sao Paulo State, Brazil, and WHO goals for 2000 and 2010. Cad Saúde Publica. v. 20, n. 3, p. 866-70, Maio - Junho, 2004. Epub 19 de maio, 2004.

GREENSTOCK, C.L. Redox processes in radiation biology and cancer. Radiat. Res. v. 86, n. 2, p. 196-211, 1981.

GUARNIERI, M.C. Estudo dos efeitos da radiação gama de Co-60 nas propriedades bioquímicas, biológicas e imunológicas do veneno de Bothrops jararaca. Dissertação apresentada ao Programa de Mestrado em Ciências (área de concentração: Tecnologia Nuclear - Aplicações), da Autarquia associada a Universidade de São Paulo, IPEN-CNEN/SP, 1992.

HILLMAN, J.D.; JOHNSON, K.P.; YAPHE, B.I. Isolation of a Streptococcus mutans strain producing a novel bacteriocin. Infect. Immun. n. 44, p. 141- 144, 1984.

JIMENEZ-PORRAS, J.M. Biochemistry of snake venoms. Clinical Toxicology, v. 3, n. 3, p. 389-431, 1970. 
KARTHIKEYAN, S.; ZHOU, Q.; ZHAO, Z.; KAO, C.L.; TAO, Z.; ROBINSON, H.; LIU, H.W.; ZHANG, H. Structural analysis of Pseudomonas 1aminocyclopropane-1-carboxylate deaminase complexes: insight into the mechanism of a unique pyridoxal-5'-phosphate dependent cyclopropane ring-opening reaction. Biochemistry v. 43, n. 42, p. 13328-39, Out. 26, 2004.

KEYS, P.H. The infectious and transmissible nature of experimental dental caries: Findings and implications. Archs oral Biol. n. 1, p. 304-320, 1960.

KÖHLER, B.; PETTERSON, B.M.; BRATTHALL, D. Streptococcus mutans in plaque and saliva and development of caries. Scand J Dent Res. n. 89, p. 19-25, 1981.

KINI, R.M. \& EVANS, H.J. A model to explain the pharmacological effects of snake venom phospholipases A2. Toxicon, v. 27, n. 6, p. 613-635, 1989.

KLEIN, M.I.; FLORIO, M.F.; PEREIRA, A.C.; HÖFLING, J.F.; GONÇALVES, R.B. Longitudinal study of transmission, diversity, and stability of Streptococcus mutans and Streptococcus sobrinus genotypes in Brazilian nurse children. J Clin Microbiol. Oct. p. 4620-4626, 2004.

KOO, H.; GOMES, B.P.F.A.; ROSALEN, P.L.; AMBROSANO, G.M.B.; PARK, Y.K.; CURY, J.A. In vitro antimicrobial activity of propolis and Arnica montana against oral pathogens. Archives of Oral Biology n. 45, p. 141-148, 2000. 
KRASSE, B. Human streptococci and experimental caries in hamsters. Archs Oral Biol. n. 11, p. 429-436, 1966.

KRASSE, B. \& CARLSSON, J. Various types of streptococci and experimental caries in hamsters. Arch. Oral Biol. n. 15, p. 25-32, 1970.

LAEMMLI, U.K. Cleavage of structural proteins during the assembly of the head bacteriophage T4. Nature v. 227, p. 680-685, 1970.

LAMONT, R.J.; DEMUTH, D.R.; DAVIS C.A.; MALAMUD D.; ROSAN B. SalivaryAgglutinin-Mediated adherence of Streptococcus mutans to early plaque bacteria. Infect. Immun. v.59, n.10, p. 3446-3450, 1991.

LAUHATIRANANANDA, P.; GUATHAVORN, S.; HAYADOM, V. Radiation effects on Cobra venom: In: International Atomic Energy Agency. Proceedings of Viena, p. 107-112, 1969.

LIZANO, S.; DOMONT, G. \& PERALES, J. Natural phospholipase A(2) myotoxin inhibitor proteins from snakes, mammals and plants. Toxicon, v. 42, n. 8, p. 963-977, 2003.

LOESCHE, W.J. \& STRAFFON, L.H. Longitudinal investigation of the role of Streptococcus mutans in human fissure decay. Infect Immun. v. 26, n. 2, p. 498-507, Nov., 1979. 
LOESCHE, W.J. Role Streptococcus mutans in human dental decay. Microbiol Rev. n. 50, p. 353-380, 1986.

MARSH, P. \& MARTIN, M.V. editores. Trad. FANTINATO, V. Microbiologia Oral. $4^{\circ}$ ed. Livraria Santos Editora Com. Imp. Ltda., São Paulo, 2005.

MASUDA, N.; TSUTSUMI, N.; SOBUE, S.; HAMADA, S. Longitudinal survey of the distribution of various serotypes of Streptococcus mutans in infants. J Clin Microbiol., n. 10, p. 497-502, 1979.

MATTOS-GRANER, R.O.; ZELANTE, F.; LINE, R.C.; MAYER, M.P. Association between caries prevalence and clinical, microbiological and dietary variables in 1.0 to 2.5 -year-old Brazilian children. Caries Res. v. 32, p. 319323, 1998.

MEIER, J. Venomous Snakes. In: STOCKER, K.F. Medical use of Snake Venom Proteins. Boca Raton, Boston: CRC, p. 1-32, 1990.

NAKANO, K.; NOMURA, R.; KAKAGAWA, I.; HAMADA, S.; OOSHIMA, T. Demonstration of Streptococcus mutans with a cell wall polysaccharide specific to a new serotype, $\mathbf{k}$, in the human oral cavity. J Clin. Microbiol. Jan, p. 198-202, 2004. 
NASCIMENTO, N.; SEEBART, C.S.; FRANCIS, B.; ROGERO, J.R.; KAISER, I.I. Influence of ionizing radiation on crotoxin: biochemical and immunological aspects. Toxicon, v. 34, n. 1, p. 123-131, 1996.

NELSON, D.L.; COX, M.M. Lehninger Principles of Biochemistry, 4를 edição, W.H. Freeman, 2005.

OLIVEIRA, B.H.; MILBOURNE, P. Fluorose dentária em incisivos superiores permanentes em crianças de escola pública do Rio de Janeiro. Rev. Saúde Pública, v. 35, n. 3, p. 276-82, 2001.

PAIK, S.; BROWN, A.; MUNRO, C.L.; CORNELISSEN, C.N.; KITTEN, T. The sloABCR operon of Streptococcus mutans encodes an Mn and Fe transport system required for endocarditic virulence and its $\mathrm{Mn}$ dependent repressor. J Bacteriol. v. 185, n. 20, p. 5967-75, Out., 2003.

PERUMAL, S.R.; GOPALAKRISHNAKONE, P.; THWIN, M.M.; CHOW, T.K.; BOW, H.; YAP, E.H.; THONG, T.W. Antibacterial activity of snake, scorpion and bee venoms: a comparison with purified venom phospholipase A2 enzymes. J Appl Microbiol. v. 102, n. 3, p. 650-9, Mar., 2007.

PESSATTI, M.L.; FONTANA, J.D.; FURTADO, M.F.D.; GUIMARAES, M.F.; ZANETTE, L.R.S.; COSTA, W.T.; BARON, M. Screening of Bothrops snake venoms for $L$ amino acid oxidase activity. App Biochem Biotech, v. 51/52, p. 197-210, 1995. 
PETERSEN, P.E. Global data on dental caries levels in age groups 12 years and 35-44 years. WHO Global Oral Health Programme. [online]. www.who.int/ncd/orh/index.htm. 2003, acessado no dia 23 de Março de 2006.

RAMOS-GOMEZ, F.J.; WEINTRAUB, J.Á.; GANSKY, A.S.; HOOVER, C.I.; FEATHERSTONE, J.D. Bacterial, behavioral, and environmental factors associated with early childhood caries. J. Clin. Pediatr. Dent. v. 26, p. 65173, 2002.

ROGERO J.R.; NASCIMENTO, N. Detoxification of snake venom using ionizing radiation. J. Venom. Anim. Toxins, v. 1, n. 1, p. 7-10, 1995.

ROGERS, A.H. Bacteriocin types of Streptococcus mutans in human mouth. Arch. Oral Biol. n. 20, p. 853-858, 1975.

ROSEN, S. \& LENNEY, W.S. Experimental dental caries in gnobiotic rats infected with Lactobacillus casei. Int Assn Dental Research Programs and Abstract. Março 1966.

ROSENFELD, G. Acidentes por animais peçonhentos. In: VERONESI, R. (ed.) Doenças infecciosas e parasitarias, 82 ed., Editora Guanabara Koogan, p. 951962, Rio de Janeiro, 1991. 
RUTALA, W.A. APIC guidelines for infection control practice: APIC guideline for selection and use of disinfectants. AJIC Am J Infect Control. n.18: p. 99-117, 1990.

SALAFRANCA, E.S. Irradiated cobra (Naja naja philippinensis) venom. Int J Appl Radiat Isot. v. 24, n. 1, Jan., 1973.

SANT'ANA, C.D. Caracterização funcional e estrutural de uma nova serinoprotease do veneno de Bothrops jararacussu. Dissertação de Mestrado apresentada ao Programa de Pós-Graduação em Toxicologia (Área de concentração: Toxicologia), 2005.

SCABAR, L.F.; ARMONIA, P.L.; TORTAMANO, N.; BARROS, F.C.; MELLO, J.A.J. O creme dental fluoretado (500 PPM F-) e o risco de fluorose dentária. Rev. Inst Ciênc Saúde. n. 22, v. 4, p. 305-309, Out/Dez, 2004.

SELIGMAN, B.G.S. Uso de antimicrobianos em clínica médica. Rev. AMRIGS, v. 48, n. 2, p. 121-125, Abr.-Jun., 2004.

SMITH, D.J.; KING, W.F.; TAUBMAN, M.A. Salivary IgA antibody to oral streptococcal antigens in predentate infants. Oral Microbiol Immunol. n. 5, p. 57-62, 1990.

SMITH, D.J. Dental caries vaccines: Prospects and concerns. Crit. Rev. Oral Biol. Med. v. 13, n. 4, p. 335-349, 2002. 
STILES, BG; SEXTON, FW. AND WENSTEIN, AS. Antibacterial effects of different snake venoms: purification and characterization of antibacterial proteins from Pseudechis australis (Australian King brown or mulga snake) venom. Toxicon. v.29, p. 1129-1141, 1991.

SKARNES, RC. L-amino acid oxidase, a bacterial system. Nature v. 225, p. $1072-$ 1073, 1970.

TAN, N-H. \& PONNUDURAI, G. A comparative study of the biological properties of Australian elapid venoms. Comp. Biochem. Physiol., v. 97, n. 1, p. 99-106, 1990.

TAN, NT. \& SAIFUDDIN, MN. Substrate specificity of King Cobra (Ophiophagus hannah) venom L-amino acid oxidase. Int. J. Biochem. v. 23, p. 323-327, 1991.

TANZER, JM.; LIVINGSTON, J.; THOMPSON, AM. The microbiology of primary dental caries in humans. J. Dent. Educ. v. 65, n.10, p. 1028-1037, 2001.

TEMPONE, A.G.; ANDRADE, H.F.; SPENCER, P.J.; LOURENÇO, C.O.; ROGERO, J.R.; NASCIMENTO, N. Bothrops moojeni venom kills leishmania spp. With hydrogen peroxide generated by its L-amino acid oxidase. Biochem Biophys Res Commun. v. 280, n. 3, p. 620-24, 2001. 
THYLSTRUP, A.; FEJERSKOV, O (ed). Tratado de Cariologia. Trad. Coord. WAYNE, S. Rio de Janeiro, Cultura Médica, p. 404, 1988.

TOYAMA, M.H.; TOYAMA, D.O.; PASSERO, L.F.D.; LAURENTI, M.D.; CORBETT, C.E.; TOMOKANE, T.Y.; FONSECA, F.V.; ANTUNES, E.; JOAZEIRO, P.P.; BERIAM, L.O.S.; MARTINS, M.A.C.; MONTEIRO, H.S.A.; FONTELES, M.C. Isolation of new L-amino acid oxidase from Crotalus durissus cascavella venom. Toxicon. v. 47, p. 47-57, 2006.

WALES, A. \& KUSEL, J.R. Biochemistry of irradiated parasite vaccines: suggested models for their mode of action. Parasitol Today. v. 8, n. 11, p. 358-63, 1992.

WARRELL, D.A. Venomous bites and stings in the tropical world. Med J Aust. v. 6-20, n. 159 (11-12), p. 773-9, Dez., 1993.

WEYNE, S. Cariologia. In: BARATIERE, LN.; ANDRADA, MAC.; MONTEIRO JUNIOR, S.; CARDOSO, AC.; POLIDORO, JS.; ANDRADA, RC.; SOUSA, CN.; BRANDEBURGO, PC.; LINS, JRS.; ANDRADE, CA., editores. Dentística. Procedimentos Preventivos e Restauradores. São Paulo: Quintessence Books; p. 1-38, 2000.

WHILEY, RA. \& BEIGHTON, D. Current classification of the oral streptococci. Oral Microbiol Immunol. v. 13, n. 4, p. 195-216, Ago., 1998. 
WHITE, J. Bites and stings from venomous animals: a global overview. Ther Drug Monit. v. 22, n. 1, p. 65-8, Fev., 2000.

WHITE, J.; POUNDER, DJ. Fatal snakebite in Australia. Am. J. Forensic Med. Pathol. v. 5, n. 2, p. 137-143, 1984.

YATSUDA, R. Efeito antimicrobiano in vitro da Mikania laevigata e da Mikania glomerata sobre estreptococos do grupo mutans. Dissertação (Mestrado) Universidade Estadual de Campinas, Faculdade de Odontologia de Piracicaba, 2004.

YOO, SY.; KIM, OS.; HWANG, HK.; LIM, SH.; KIM, KW.; CHOE, SJ.; MIN, BM.; $\mathrm{KOOK}, \mathrm{JK}$. Identification of non-mutans streptococci organisms in dental plaques recovering on mitis-salivarius bacitracin agar medium. $\mathrm{J}$ Microbiol. v. 43, n. 2, p. 204-8, Apr., 2005.

ZINNER, DD.; JABLON, JM.; ARAN, AP.; SASLAW, MS. Experimental caries induced in animals by streptococci of human origin. Proc Soc Exp Biol Med. n. 118, p. 766-770, 1965. 


\section{ANEXOS}

\section{Bothrops jararacussu}

Gráficos de 1 a 12: São plotados os resultados da atividade bactericida em função do tempo, na presença ou ausência de catalase na concentração de $2 \mathrm{mg} / \mathrm{mL}$.

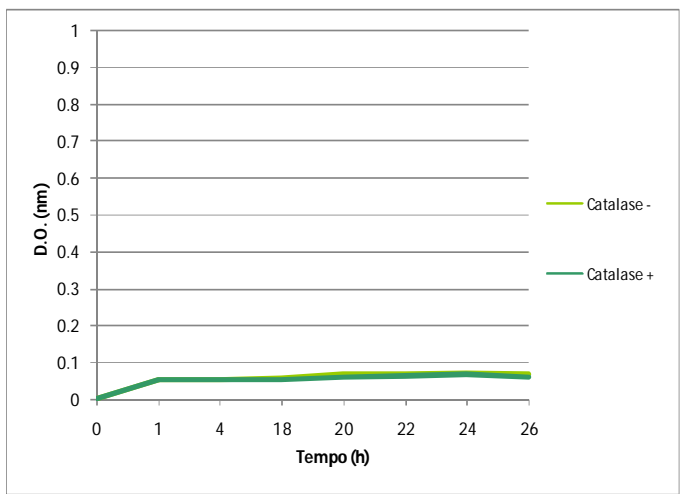

Gráfico 1: Meio de cultura (BHI)

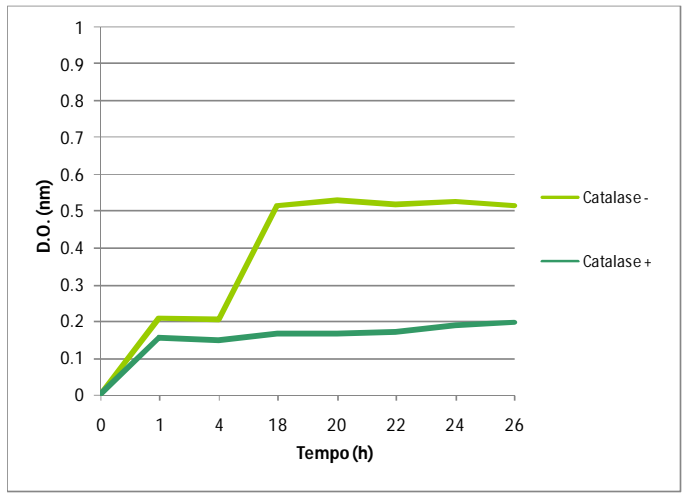

Gráfico 3: Meio de cultura (BHI) + Bactérias a concentração aproximada de $2,63 \times 10^{6} \mathrm{CFU} / \mathrm{mL}^{-1}+4 \times 10^{-2} \mu \mathrm{g}$ de veneno

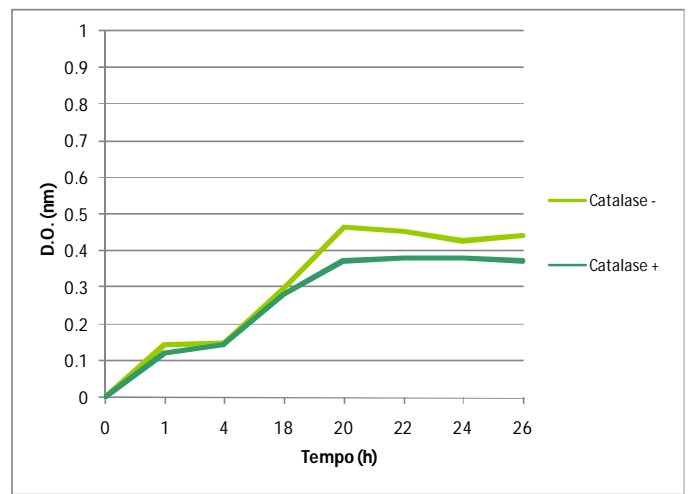

Gráfico 2: Meio de cultura (BHI) + Bactérias a concentração aproximada de $2,63 \times 10^{6} \mathrm{CFU} / \mathrm{mL}^{-1}$

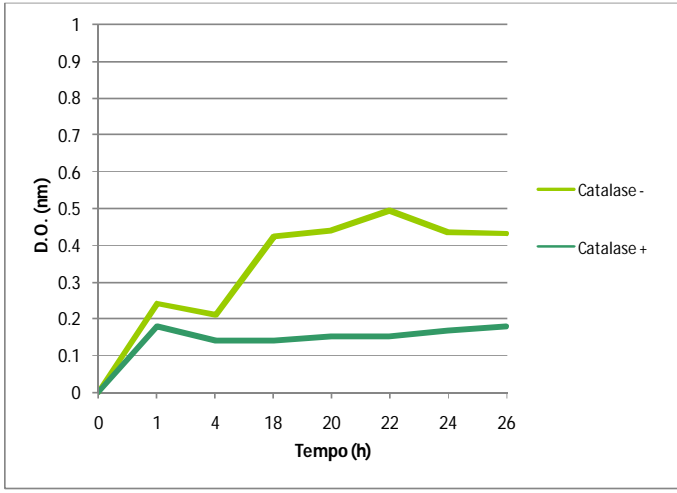

Gráfico 4: Meio de cultura (BHI) + Bactérias a concentração aproximada de $2,63 \times 10^{6} \mathrm{CFU} / \mathrm{mL}^{-1}+2 \times 10^{-2} \mu \mathrm{g}$ de veneno 


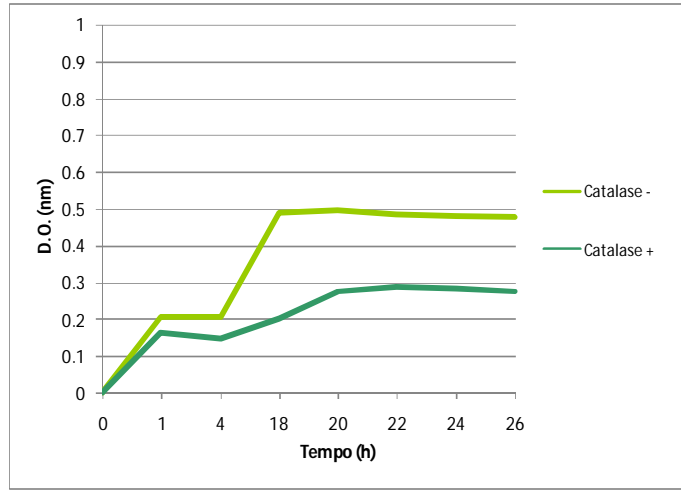

Gráfico 5: Meio de cultura (BHI) + Bactérias a concentração aproximada de $2,63 \times 10^{6} \mathrm{CFU} / \mathrm{mL}^{-1}+1 \times 10^{-2} \mu \mathrm{g}$ de veneno

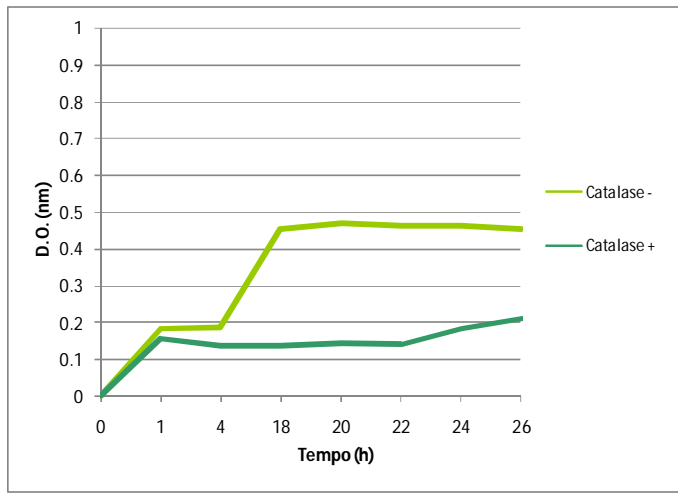

Gráfico 6: Meio de cultura (BHI) + Bactérias a concentração aproximada de $2,63 \times 10^{6} \mathrm{CFU} / \mathrm{mL}^{-1}+5 \times 10^{-3} \mu \mathrm{g}$ de veneno

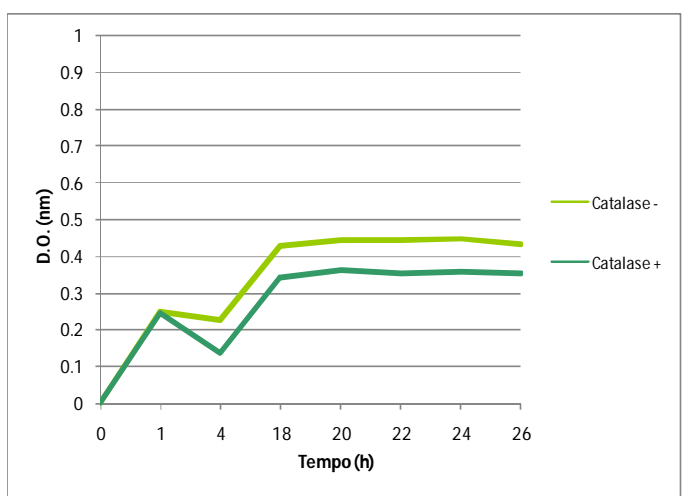

Gráfico 7: Meio de cultura (BHI) + Bactérias a concentração aproximada de $2,63 \times 10^{6} \mathrm{CFU} / \mathrm{mL}^{-1}+2,5 \times 10^{-5} \mu \mathrm{g}$ de veneno

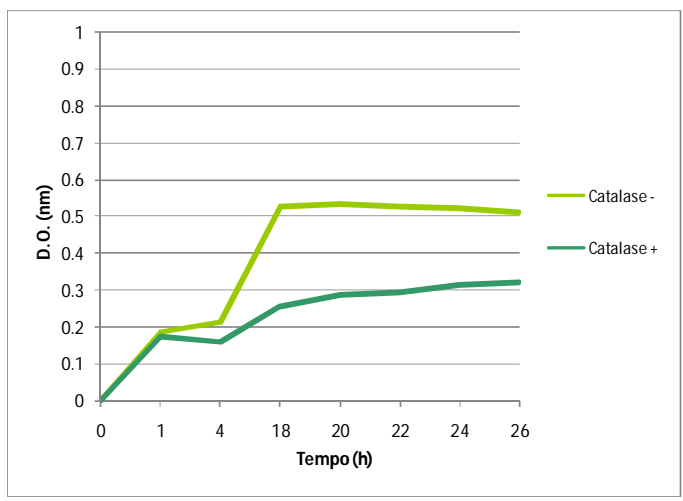

Gráfico 9: Meio de cultura (BHI) + Bactérias a concentração aproximada de $2,63 \times 10^{6} \mathrm{CFU} / \mathrm{mL}^{-1}+6,25 \times 10^{-8} \mu \mathrm{g}$ de veneno

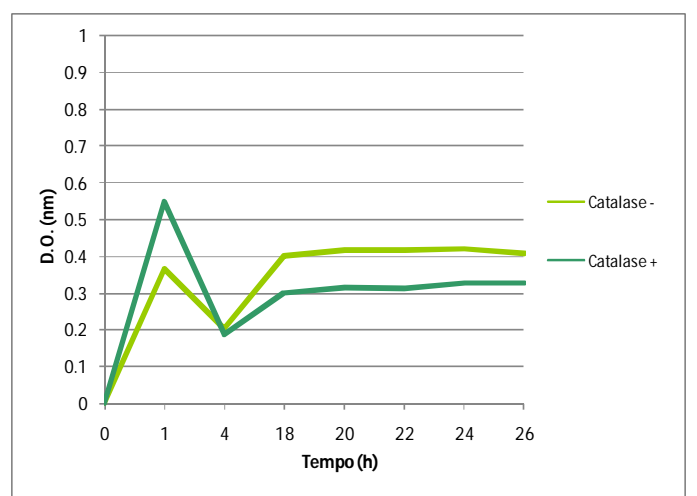

Gráfico 8: Meio de cultura (BHI) + Bactérias a concentração aproximada de $2,63 \times 10^{6} \mathrm{CFU} / \mathrm{mL}^{-1}+1,25 \times 10^{-7} \mu \mathrm{g}$ de veneno

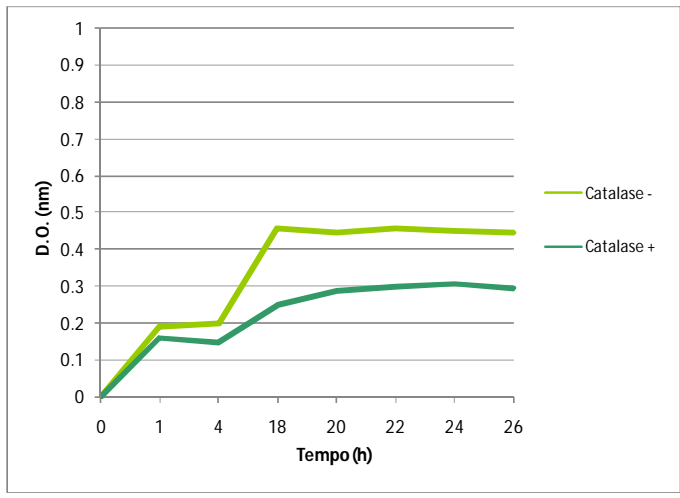

Gráfico 10: Meio de cultura (BHI) + Bactérias a concentração aproximada de $2,63 \times 10^{6} \mathrm{CFU} / \mathrm{mL}^{-1}+3,25 \times 10^{-10} \mu \mathrm{g}$ de veneno 
MOSCA, R.C., 2008

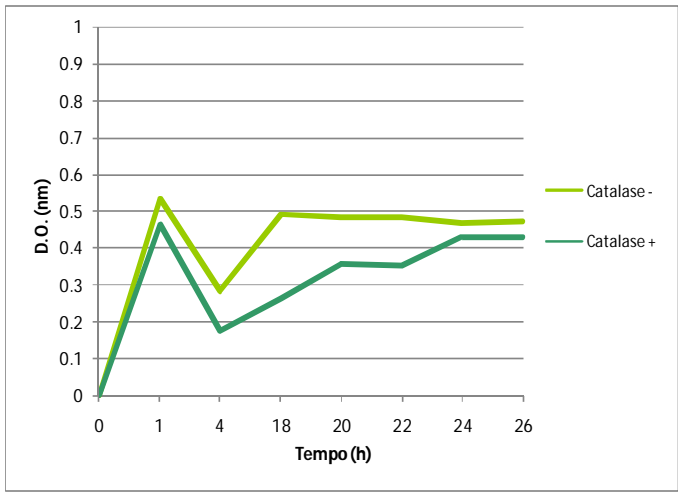

Gráfico 11: Meio de cultura (BHI) + Bactérias a concentração aproximada de $2,63 \times 10^{6} \mathrm{CFU} / \mathrm{mL}^{-1}+1,5625 \times 10^{-12} \mu \mathrm{g}$ de veneno

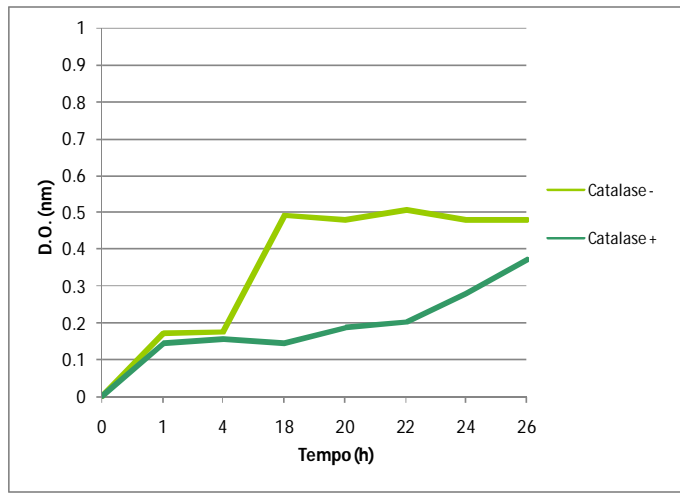

Gráfico 12: Meio de cultura (BHI) + Bactérias a concentração aproximada de $2,63 \times 10^{6} \mathrm{CFU} / \mathrm{mL}^{-1}+7,8125 \times 10^{-13} \mu \mathrm{g}$ de veneno 
Gráficos de 13 a 24: São plotados os resultados da atividade bactericida em função do tempo, na presença ou ausência de catalase na concentração de $2 \mathrm{mg} / \mathrm{mL}$.

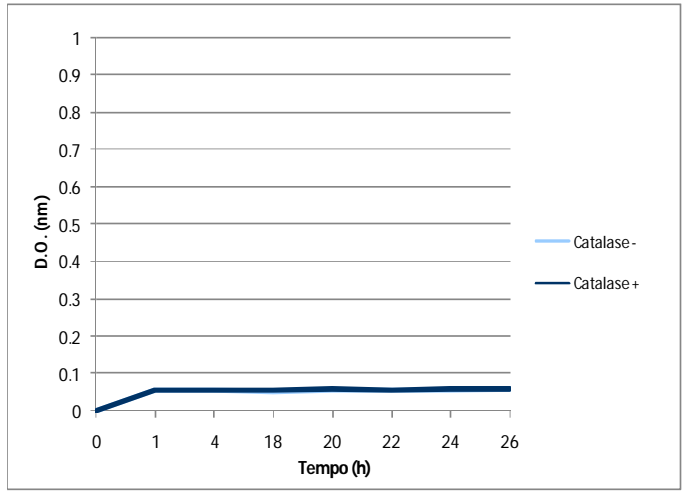

Gráfico 13: Meio de cultura (BHI)

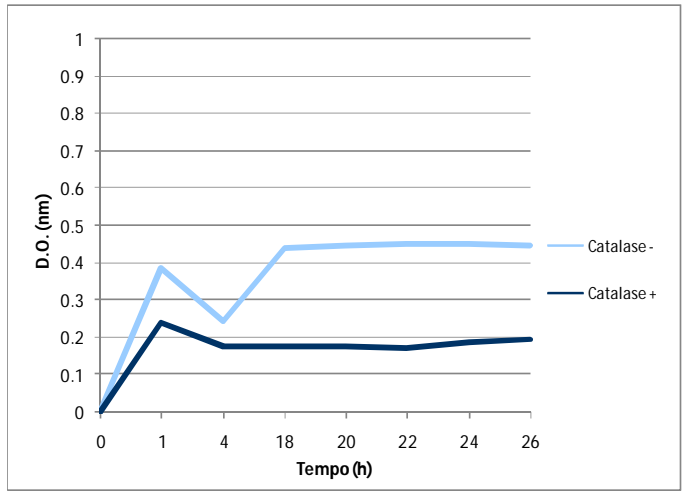

Gráfico 15: Meio de cultura (BHI) + Bactérias a concentração aproximada de $2,63 \times 10^{6} \mathrm{CFU} / \mathrm{mL}^{-1}+4 \times 10^{-2} \mu \mathrm{g}$ de veneno

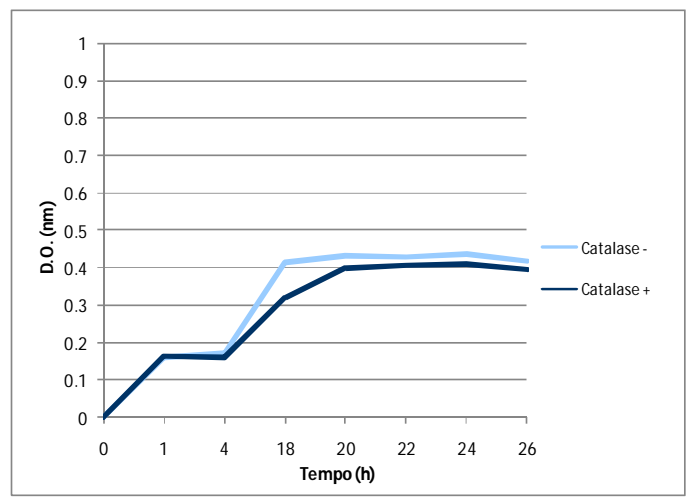

Gráfico 14: Meio de cultura (BHI) + Bactérias a concentração aproximada de $2,63 \times 10^{6} \mathrm{CFU} / \mathrm{mL}^{-1}$

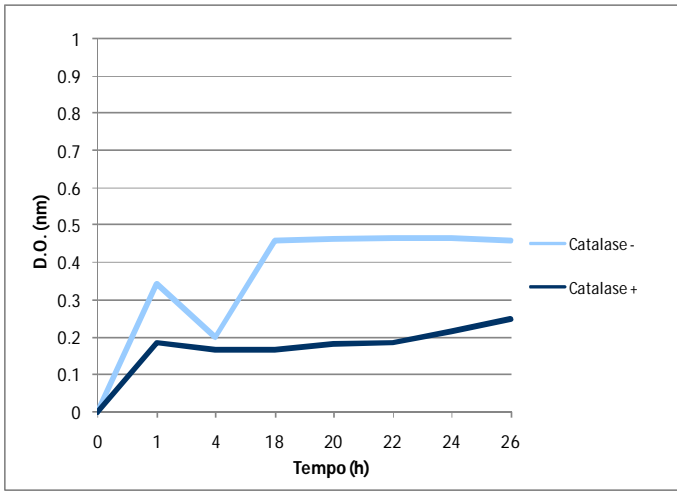

Gráfico 16: Meio de cultura (BHI) + Bactérias a concentração aproximada de $2,63 \times 10^{6} \mathrm{CFU} / \mathrm{mL}^{-1}+2 \times 10^{-2} \mu \mathrm{g}$ de veneno 


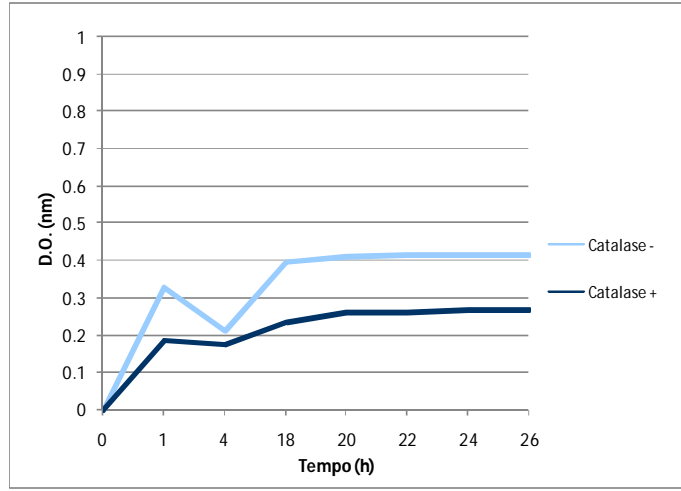

Gráfico 17: Meio de cultura (BHI) + Bactérias a concentração aproximada de $2,63 \times 10^{6} \mathrm{CFU} / \mathrm{mL}^{-1}+1 \times 10^{-2} \mu \mathrm{g}$ de veneno

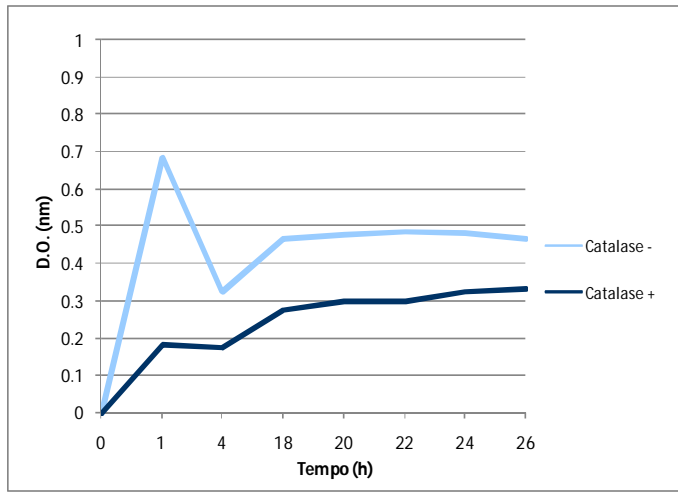

Gráfico 18: Meio de cultura (BHI) + Bactérias a concentração aproximada de $2,63 \times 10^{6} \mathrm{CFU} / \mathrm{mL}^{-1}+5 \times 10^{-3} \mu \mathrm{g}$ de veneno

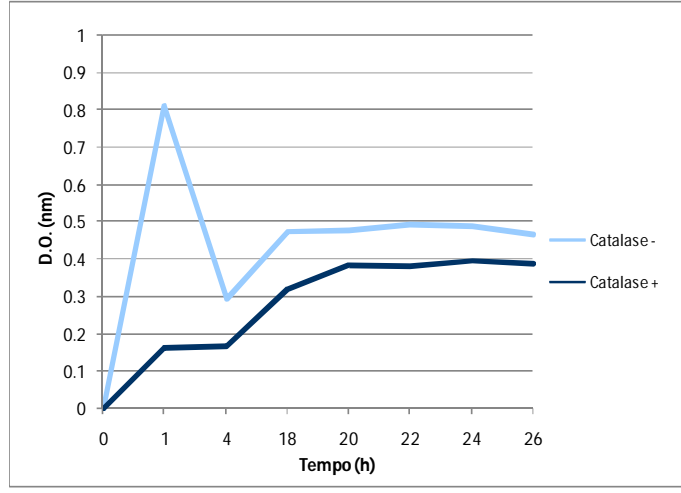

Gráfico 19: Meio de cultura (BHI) + Bactérias a concentração aproximada de $2,63 \times 10^{6} \mathrm{CFU} / \mathrm{mL}^{-1}+2,5 \times 10^{-5} \mu \mathrm{g}$ de veneno

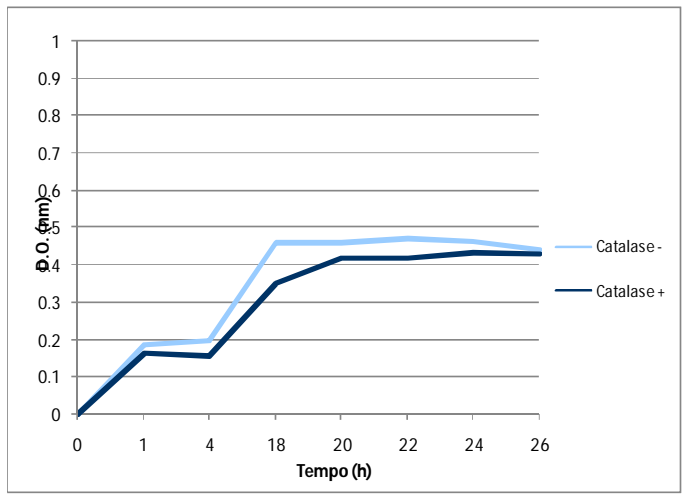

Gráfico 21: Meio de cultura (BHI) + Bactérias a concentração aproximada de $2,63 \times 10^{6} \mathrm{CFU} / \mathrm{mL}^{-1}+6,25 \times 10^{-8} \mathrm{\mu g}$ de veneno

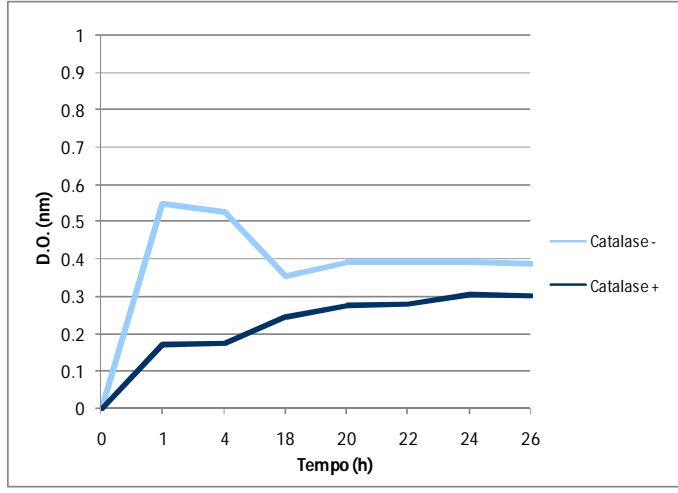

Gráfico 20: Meio de cultura (BHI) + Bactérias a concentração aproximada de $2,63 \times 10^{6} \mathrm{CFU} / \mathrm{mL}^{-1}+1,25 \times 10^{-7} \mu \mathrm{g}$ de veneno

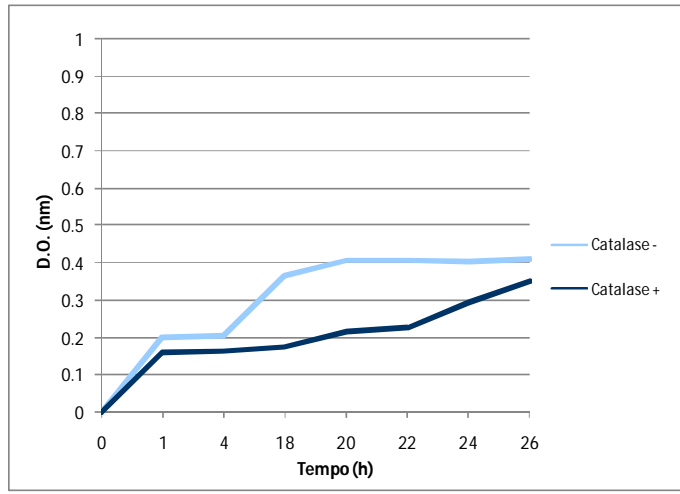

Gráfico 22: Meio de cultura (BHI) + Bactérias a concentração aproximada de $2,63 \times 10^{6} \mathrm{CFU} / \mathrm{mL}^{-1}+3,25 \times 10^{-10} \mu \mathrm{g}$ de veneno 
MOSCA, R.C., 2008

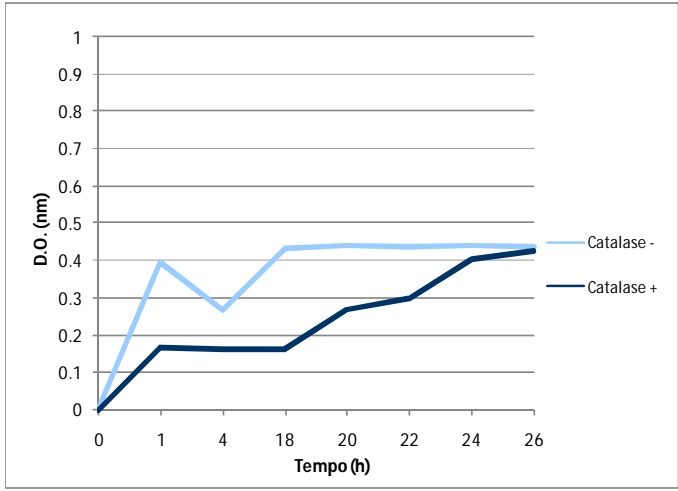

Gráfico 23: Meio de cultura (BHI) + Bactérias a concentração aproximada de $2,63 \times 10^{6} \mathrm{CFU} / \mathrm{mL}^{-1}+1,5625 \times 10^{-12} \mu \mathrm{g}$ de veneno

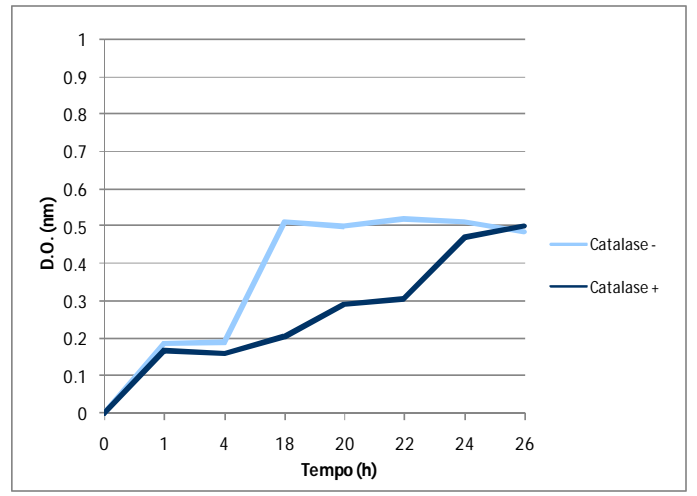

Gráfico 24: Meio de cultura (BHI) + Bactérias a concentração aproximada de $2,63 \times 10^{6} \mathrm{CFU} / \mathrm{mL}^{-1}+7,8125 \times 10^{-13} \mu \mathrm{g}$ de veneno 
Gráficos de 25 a 36 - Referente à fração do Pico 1: São plotados os resultados da atividade bactericida em função do tempo, na presença ou ausência de catalase na concentração de $2 \mathrm{mg} / \mathrm{mL}$.

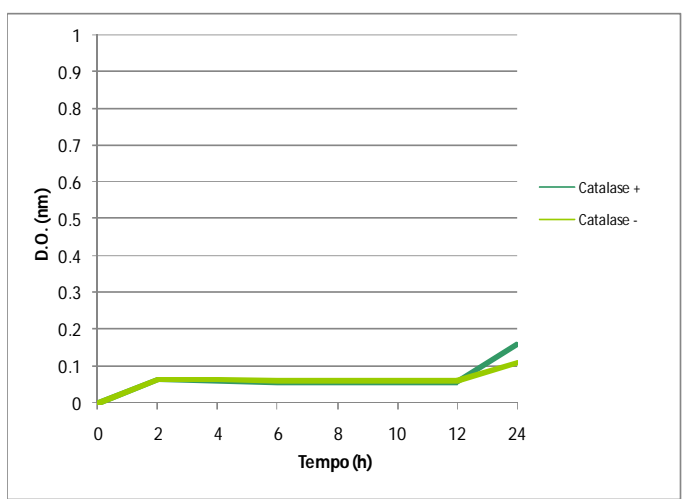

Gráfico 25: Meio de cultura (BHI)

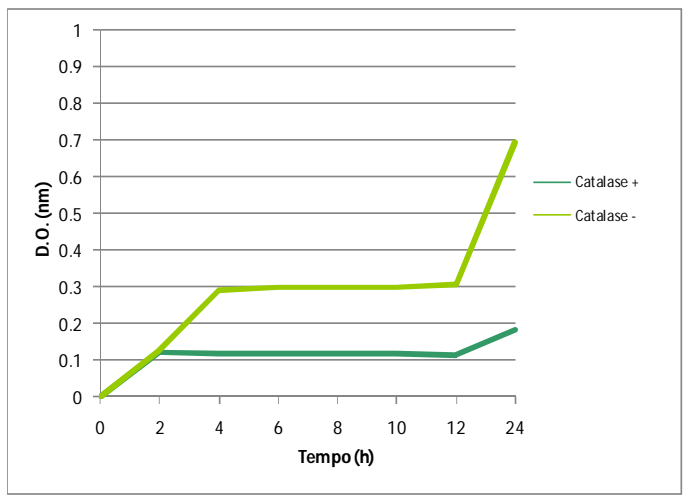

Gráfico 27: Meio de cultura (BHI) + Bactérias a concentração aproximada de $2,63 \times 10^{6} \mathrm{CFU} / \mathrm{mL}^{-1}+4 \times 10^{-2} \mu \mathrm{g}$ de veneno

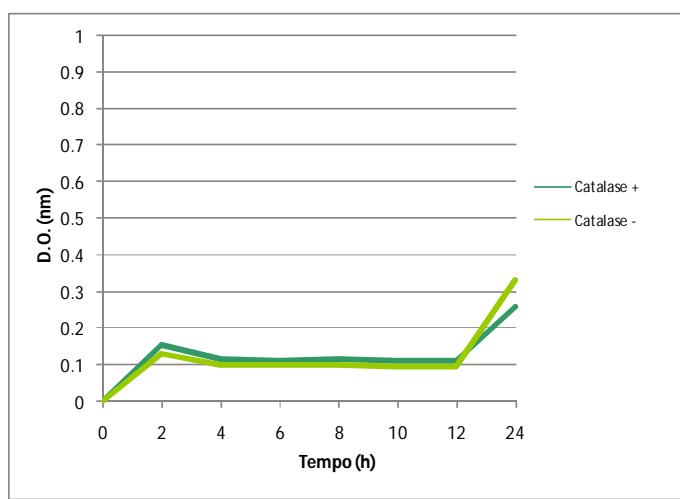

Gráfico 26: Meio de cultura (BHI) + Bactérias a concentração aproximada de $2,63 \times 10^{6} \mathrm{CFU} / \mathrm{mL}^{-1}$

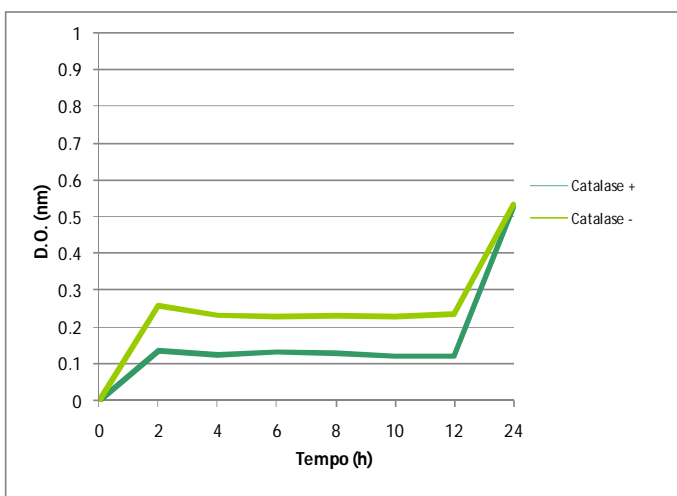

Gráfico 28: Meio de cultura (BHI) + Bactérias a concentração aproximada de $2,63 \times 10^{6} \mathrm{CFU} / \mathrm{mL}^{-1}+2 \times 10^{-2} \mu \mathrm{g}$ de veneno 


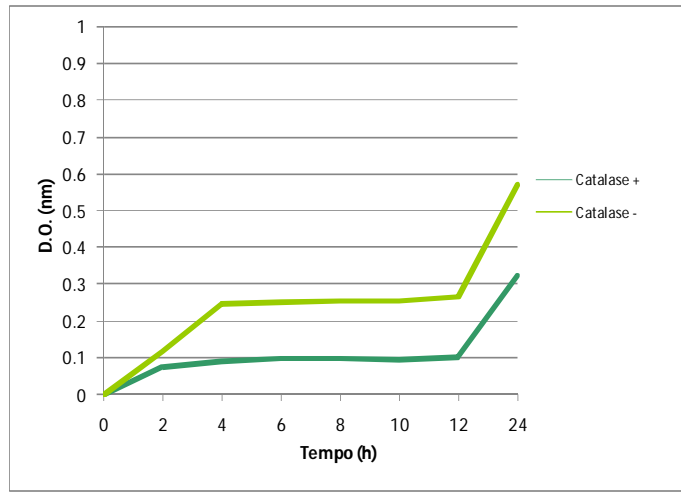

Gráfico 29: Meio de cultura (BHI) + Bactérias a concentração aproximada de $2,63 \times 10^{6} \mathrm{CFU} / \mathrm{mL}^{-1}+1 \times 10^{-2} \mu \mathrm{g}$ de veneno

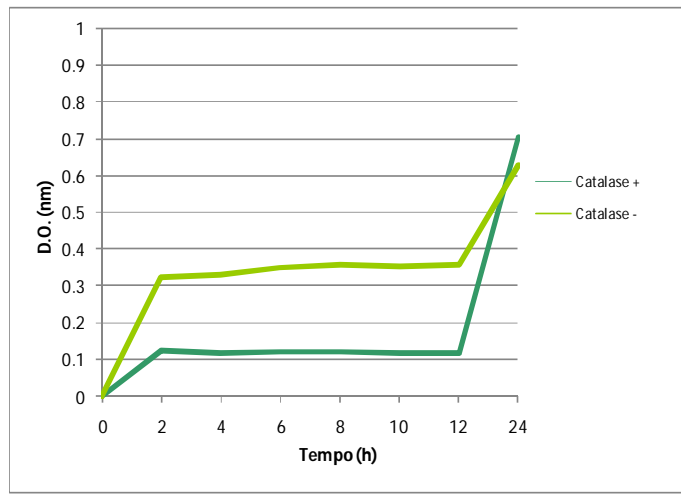

Gráfico 31: Meio de cultura (BHI) + Bactérias a concentração aproximada de $2,63 \times 10^{6} \mathrm{CFU} / \mathrm{mL}^{-1}+2,5 \times 10^{-5} \mu \mathrm{g} d e$ veneno

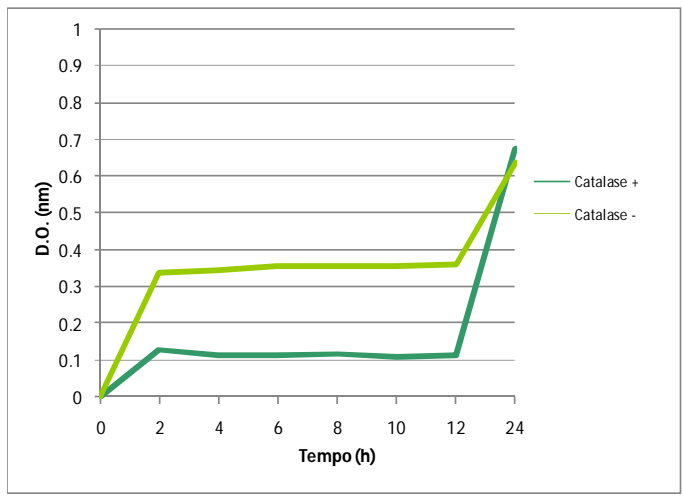

Gráfico 33: Meio de cultura (BHI) + Bactérias a concentração aproximada de $2,63 \times 10^{6} \mathrm{CFU} / \mathrm{mL}^{-1}+6,25 \times 10^{-8} \mu \mathrm{g}$ de veneno

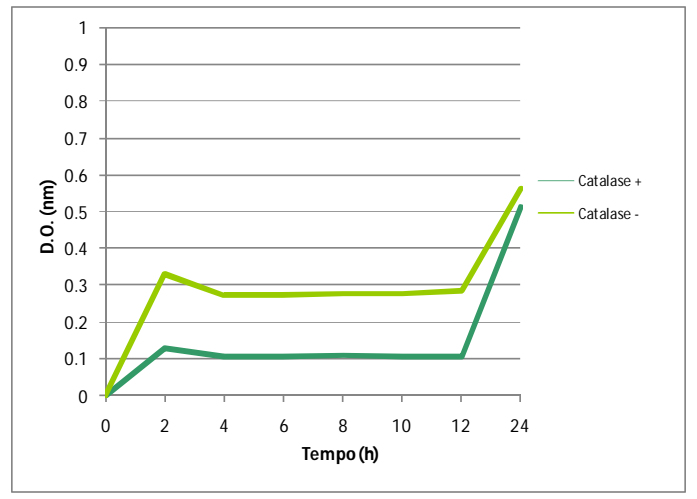

Gráfico 30: Meio de cultura (BHI) + Bactérias a concentração aproximada de $2,63 \times 10^{6} \mathrm{CFU} / \mathrm{mL}^{-1}+5 \times 10^{-3} \mu \mathrm{g}$ de veneno

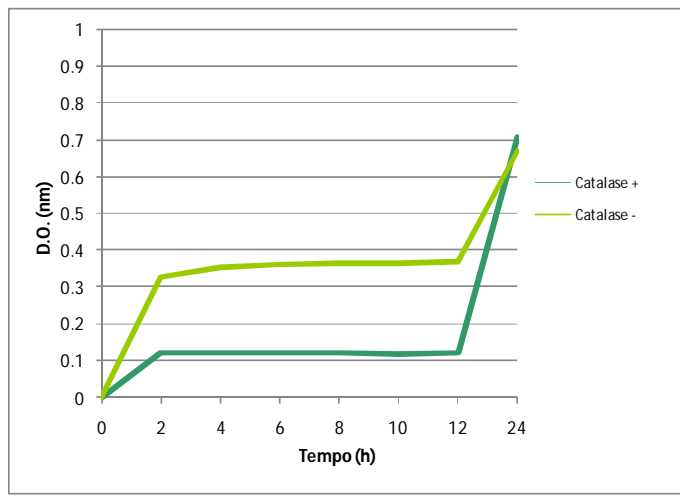

Gráfico 32: Meio de cultura (BHI) + Bactérias a concentração aproximada de $2,63 \times 10^{6} \mathrm{CFU} / \mathrm{mL}^{-1}+1,25 \times 10^{-7} \mu \mathrm{g}$ de veneno

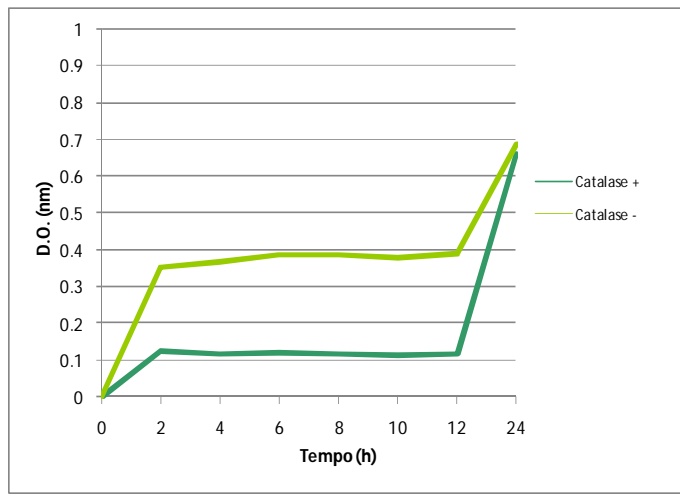

Gráfico 34: Meio de cultura (BHI) + Bactérias a concentração aproximada de $2,63 \times 10^{6} \mathrm{CFU} / \mathrm{mL}^{-1}+3,25 \times 10^{-10} \mu \mathrm{g}$ de veneno 
MOSCA, R.C., 2008

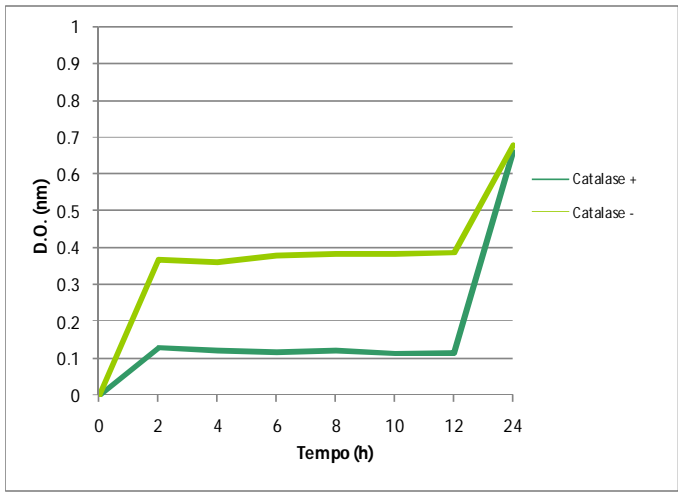

Gráfico 35: Meio de cultura (BHI) + Bactérias a concentração aproximada de $2,63 \times 10^{6} \mathrm{CFU} / \mathrm{mL}^{-1}+1,5625 \times 10^{-12} \mu \mathrm{g}$ de veneno

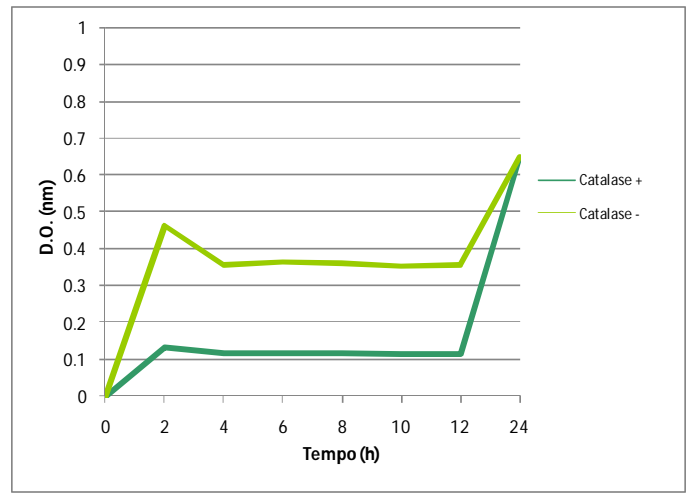

Gráfico 36: Meio de cultura (BHI) + Bactérias a concentração aproximada de $2,63 \times 10^{6} \mathrm{CFU} / \mathrm{mL}^{-1}+7,8125 \times 10^{-13} \mu \mathrm{g}$ de veneno 
Gráficos de 37 a 48 - Referente à fração do pico 4: São plotados os resultados da atividade bactericida em função do tempo, na presença ou ausência de catalase na concentração de $2 \mathrm{mg} / \mathrm{mL}$.

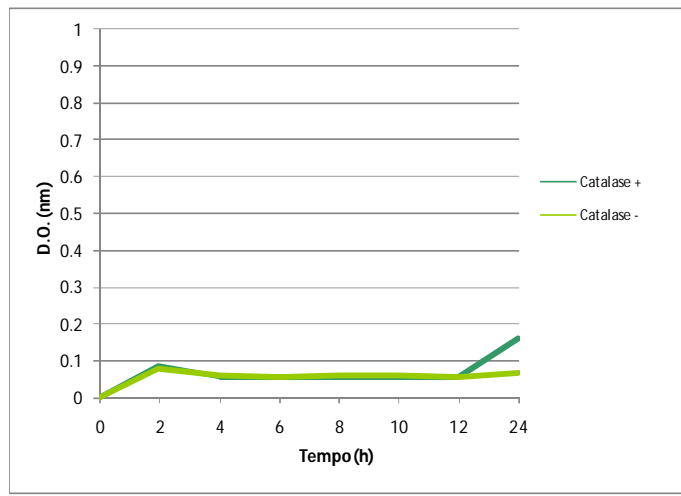

Gráfico 37: Meio de cultura (BHI)

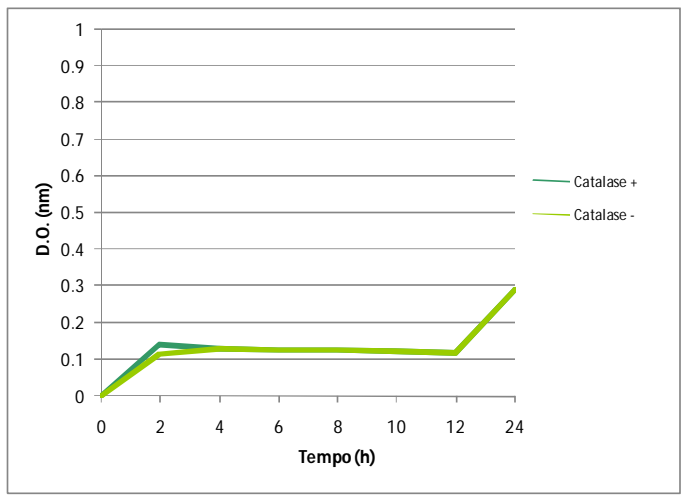

Gráfico 38: Meio de cultura (BHI) + Bactérias a concentração aproximada de $2,63 \times 10^{6} \mathrm{CFU} / \mathrm{mL}^{-1}$

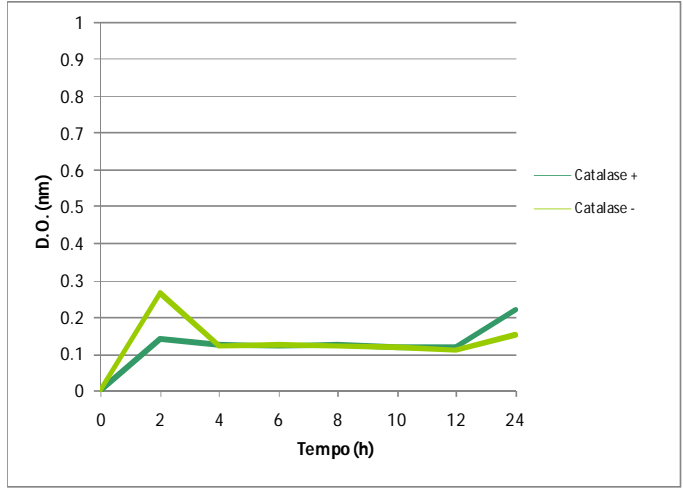

Gráfico 39: Meio de cultura (BHI) + Bactérias a concentração aproximada de $2,63 \times 10^{6} \mathrm{CFU} / \mathrm{mL}^{-1}+4 \times 10^{-2} \mu \mathrm{g}$ de veneno

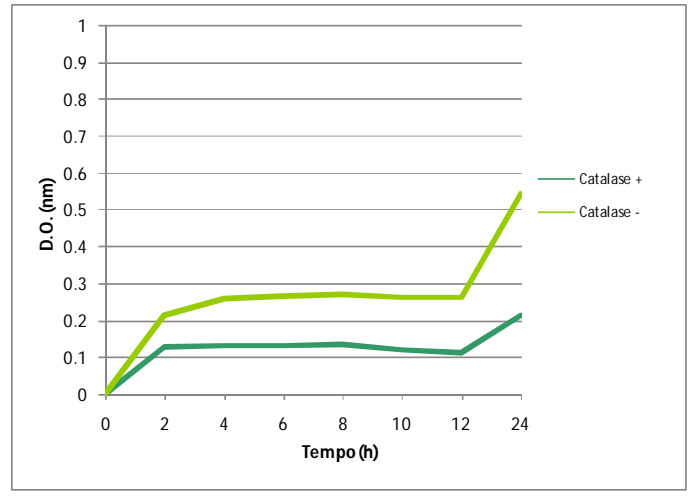

Gráfico 40: Meio de cultura (BHI) + Bactérias a concentração aproximada de $2,63 \times 10^{6} \mathrm{CFU} / \mathrm{mL}^{-1}+2 \times 10^{-2} \mu \mathrm{g}$ de veneno 


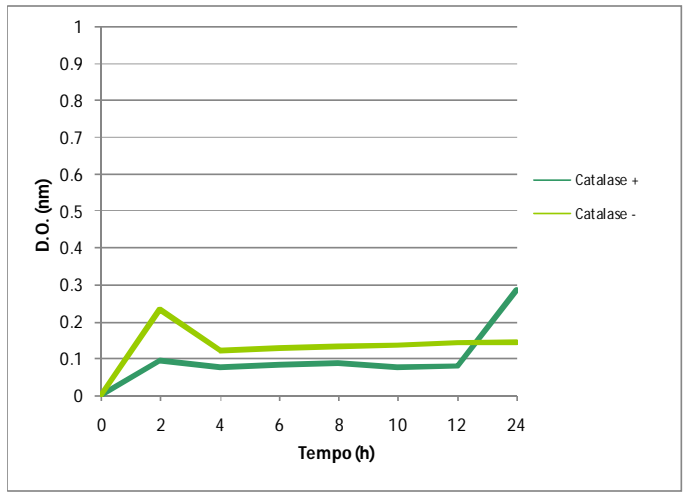

Gráfico 41: Meio de cultura (BHI) + Bactérias a concentração aproximada de $2,63 \times 10^{6} \mathrm{CFU} / \mathrm{mL}^{-1}+1 \times 10^{-2} \mu \mathrm{g}$ de veneno

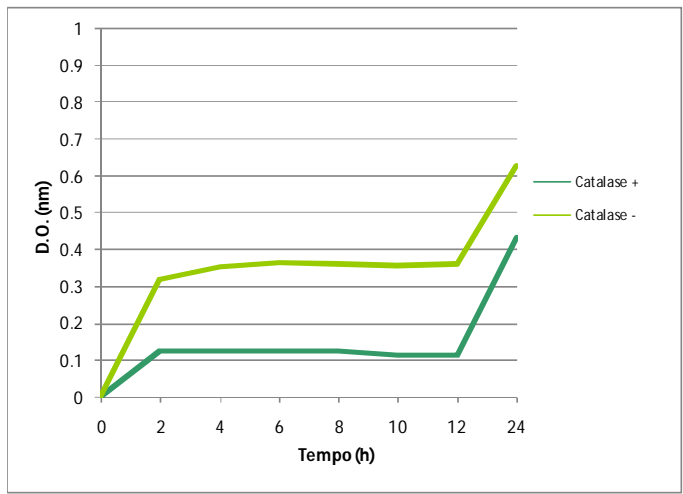

Gráfico 43: Meio de cultura (BHI) + Bactérias a concentração aproximada de $2,63 \times 10^{6} \mathrm{CFU} / \mathrm{mL}^{-1}+2,5 \times 10^{-5} \mu \mathrm{g}$ de veneno

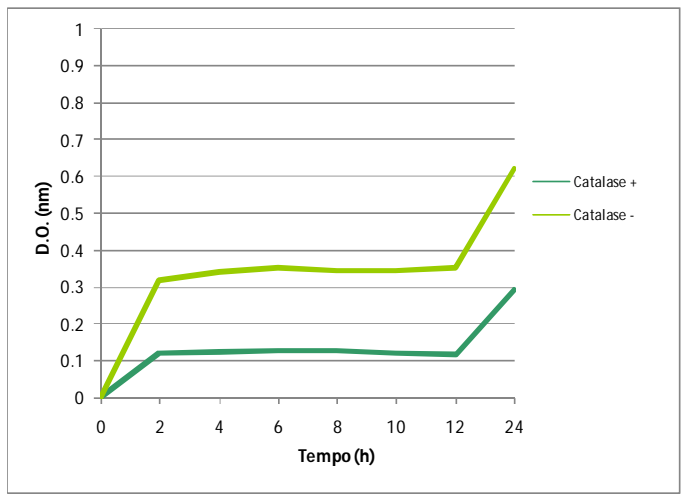

Gráfico 45: Meio de cultura (BHI) + Bactérias a concentração aproximada de $2,63 \times 10^{6} \mathrm{CFU} / \mathrm{mL}^{-1}+6,25 \times 10^{-8} \mu \mathrm{g}$ de veneno

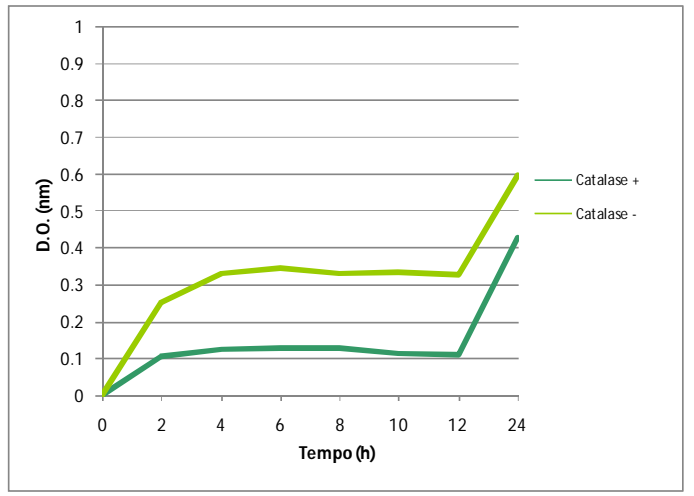

Gráfico 42: Meio de cultura (BHI) + Bactérias a concentração aproximada de $2,63 \times 10^{6} \mathrm{CFU} / \mathrm{mL}^{-1}+5 \times 10^{-3} \mu \mathrm{g}$ de veneno

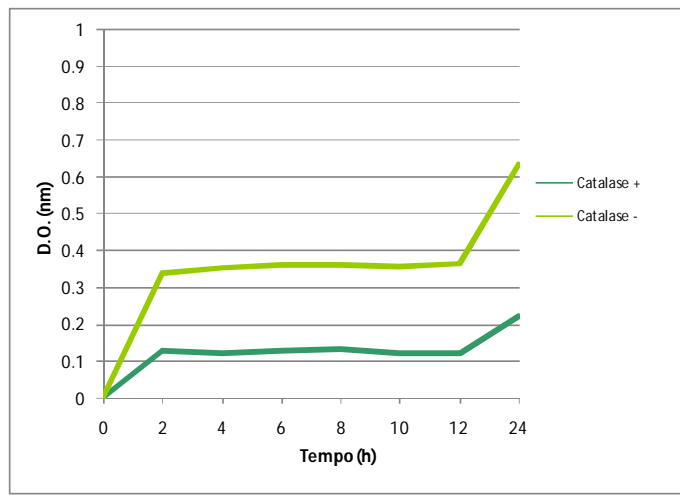

Gráfico 44: Meio de cultura (BHI) + Bactérias a concentração aproximada de $2,63 \times 10^{6} \mathrm{CFU} / \mathrm{mL}^{-1}+1,25 \times 10^{-7} \mu \mathrm{g}$ de veneno

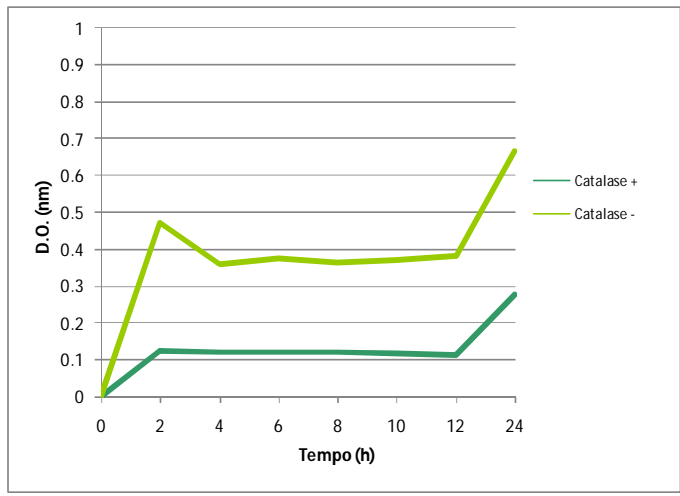

Gráfico 46: Meio de cultura (BHI) + Bactérias a concentração aproximada de $2,63 \times 10^{6} \mathrm{CFU} / \mathrm{mL}^{-1}+3,25 \times 10^{-10} \mu \mathrm{g}$ de veneno 


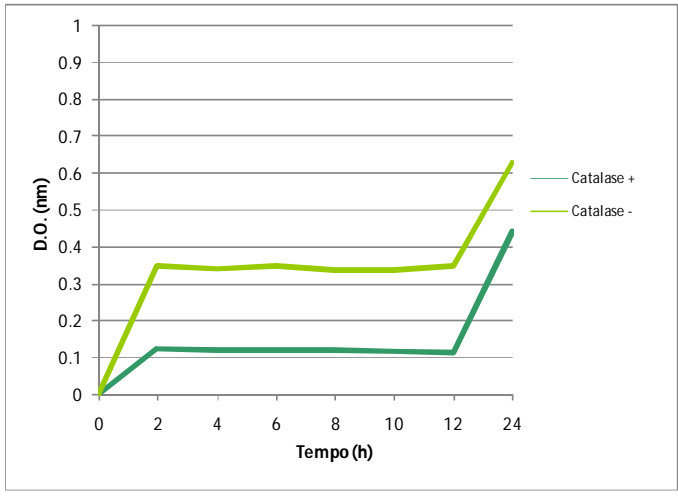

Gráfico 47: Meio de cultura (BHI) + Bactérias a concentração aproximada de $2,63 \times 10^{6} \mathrm{CFU} / \mathrm{mL}^{-1}+1,5625 \times 10^{-12} \mu \mathrm{g}$ de veneno

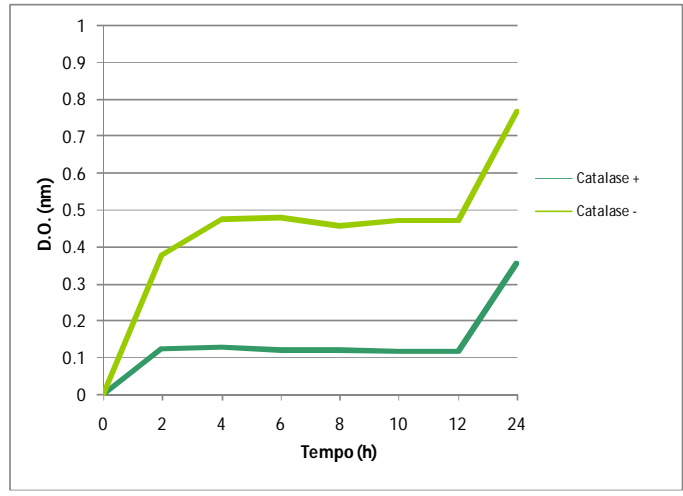

Gráfico 48: Meio de cultura (BHI) + Bactérias a concentração aproximada de $2,63 \times 10^{6} \mathrm{CFU} / \mathrm{mL}^{-1}+7,8125 \times 10^{-13} \mu \mathrm{g}$ de veneno 
Gráficos de 49 a 60 - Referente à fração do pico 1: São plotados os resultados da atividade bactericida em função do tempo, na presença (verde claro - AB) ou ausência de catalase - concentração de $2 \mathrm{mg} / \mathrm{mL}$ (verde escuro CD).

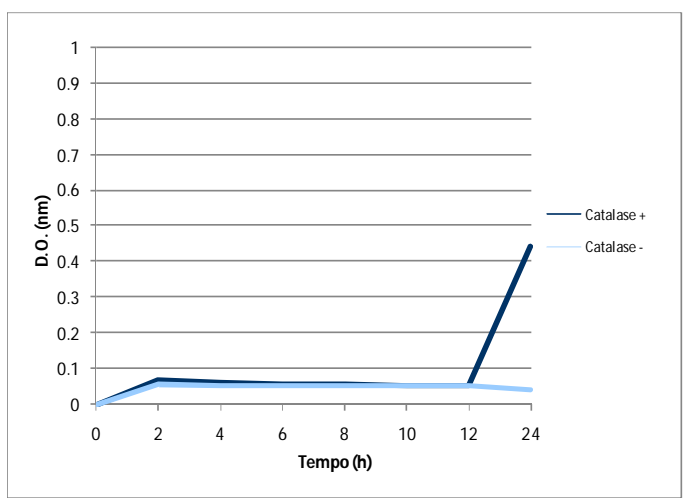

Gráfico 49: Meio de cultura (BHI)

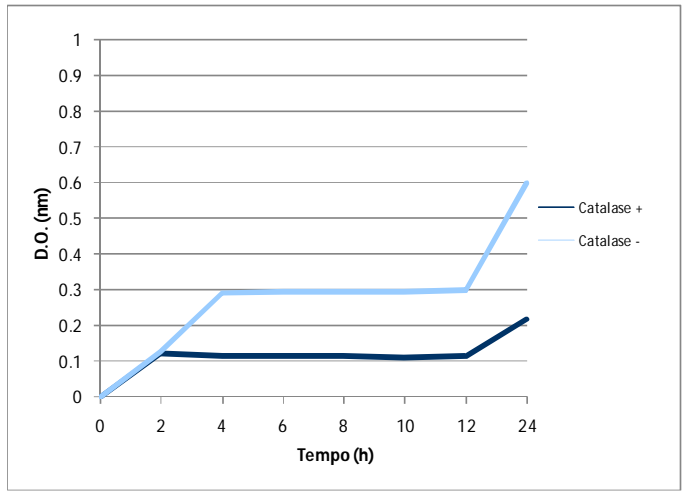

Gráfico 51: Meio de cultura (BHI) + Bactérias a concentração aproximada de $2,63 \times 10^{6} \mathrm{CFU} / \mathrm{mL}^{-1}+4 \times 10^{-2} \mu \mathrm{g}$ de veneno

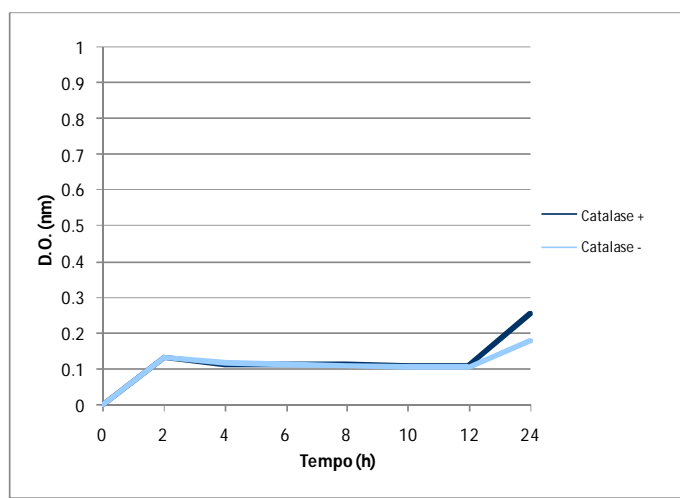

Gráfico 50: Meio de cultura (BHI) + Bactérias a concentração aproximada de $2,63 \times 10^{6} \mathrm{CFU} / \mathrm{mL}^{-1}$

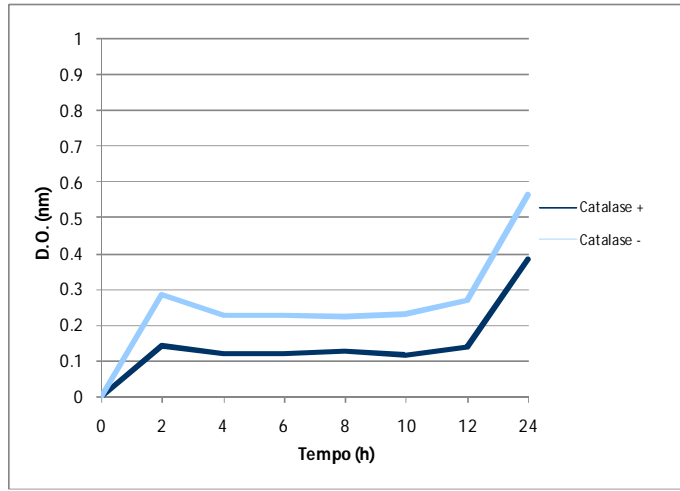

Gráfico 52: Meio de cultura (BHI) + Bactérias a concentração aproximada de $2,63 \times 10^{6} \mathrm{CFU} / \mathrm{mL}^{-1}+2 \times 10^{-2} \mu \mathrm{g}$ de veneno 


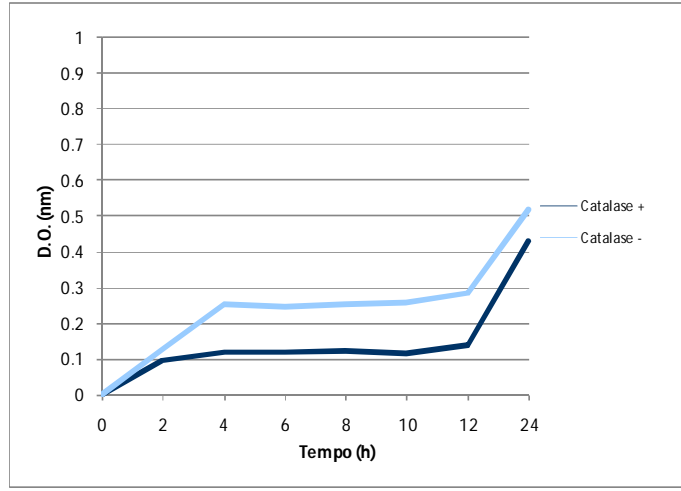

Gráfico 53: Meio de cultura (BHI) + Bactérias a concentração aproximada de $2,63 \times 10^{6} \mathrm{CFU} / \mathrm{mL}^{-1}+1 \times 10^{-2} \mu \mathrm{g}$ de veneno

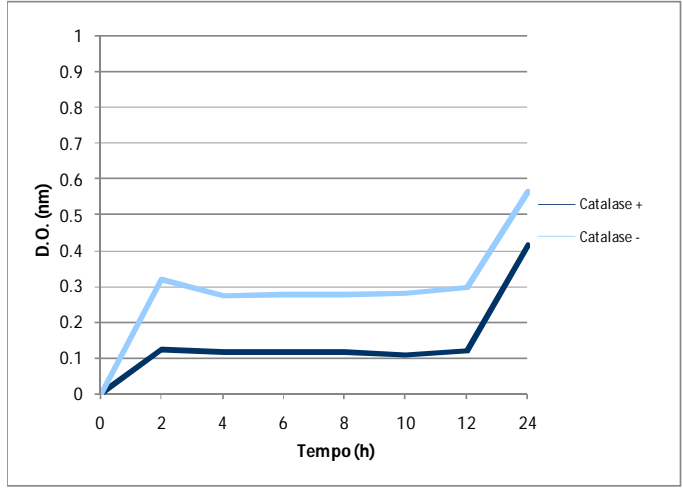

Gráfico 55: Meio de cultura (BHI) + Bactérias a concentração aproximada de $2,63 \times 10^{6} \mathrm{CFU} / \mathrm{mL}^{-1}+2,5 \times 10^{-5} \mu \mathrm{g}$ de veneno

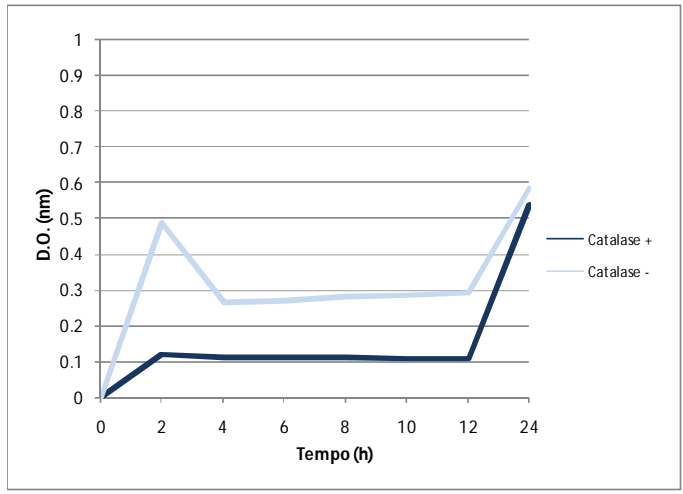

Gráfico 57: Meio de cultura (BHI) + Bactérias a concentração aproximada de $2,63 \times 10^{6} \mathrm{CFU} / \mathrm{mL}^{-1}+6,25 \times 10^{-8} \mu \mathrm{g}$ de veneno

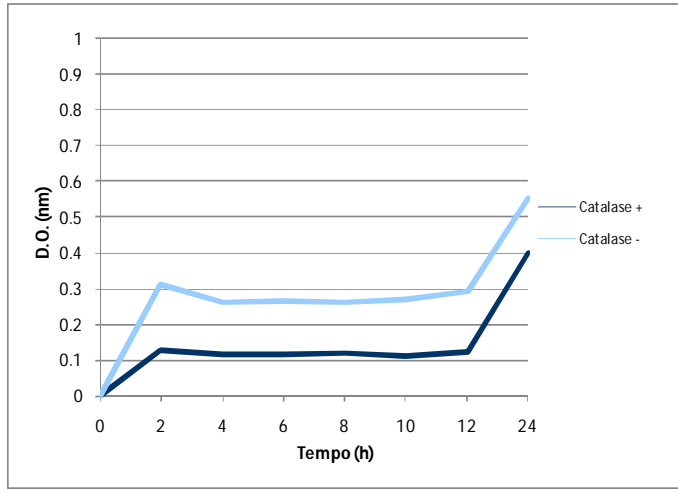

Gráfico 54: Meio de cultura (BHI) + Bactérias a concentração aproximada de $2,63 \times 10^{6} \mathrm{CFU} / \mathrm{mL}^{-1}+5 \times 10^{-3} \mu \mathrm{g}$ de veneno

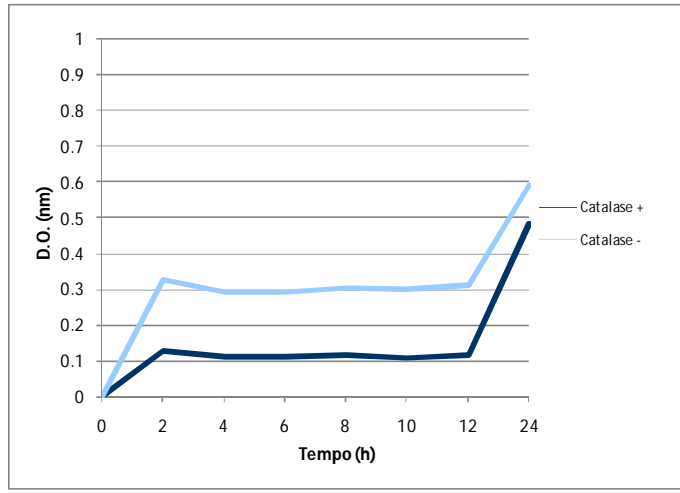

Gráfico 56: Meio de cultura (BHI) + Bactérias a concentração aproximada de $2,63 \times 10^{6} \mathrm{CFU} / \mathrm{mL}^{-1}+1,25 \times 10^{-7} \mu \mathrm{g}$ de veneno

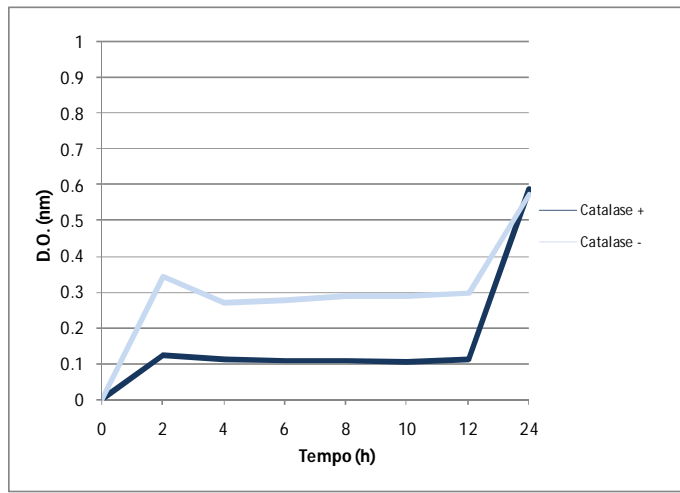

Gráfico 58: Meio de cultura (BHI) + Bactérias a concentração aproximada de $2,63 \times 10^{6} \mathrm{CFU} / \mathrm{mL}^{-1}+3,25 \times 10^{-10} \mu \mathrm{g}$ de veneno 
MOSCA, R.C., 2008

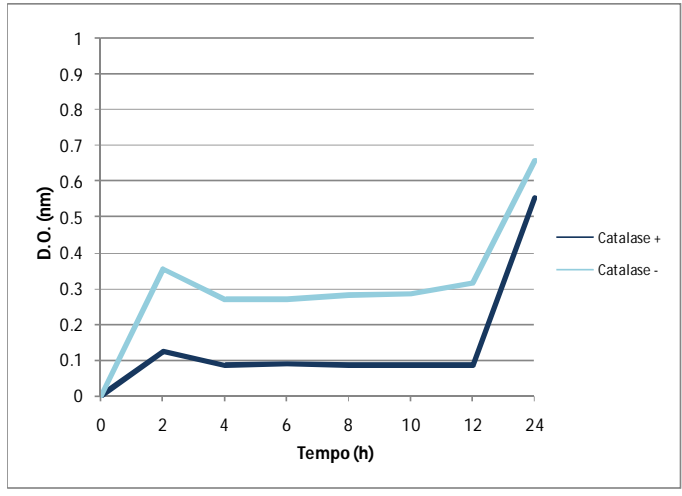

Gráfico 59: Meio de cultura (BHI) + Bactérias a concentração aproximada de $2,63 \times 10^{6} \mathrm{CFU} / \mathrm{mL}^{-1}+1,5625 \times 10^{-12} \mu \mathrm{g}$ de veneno

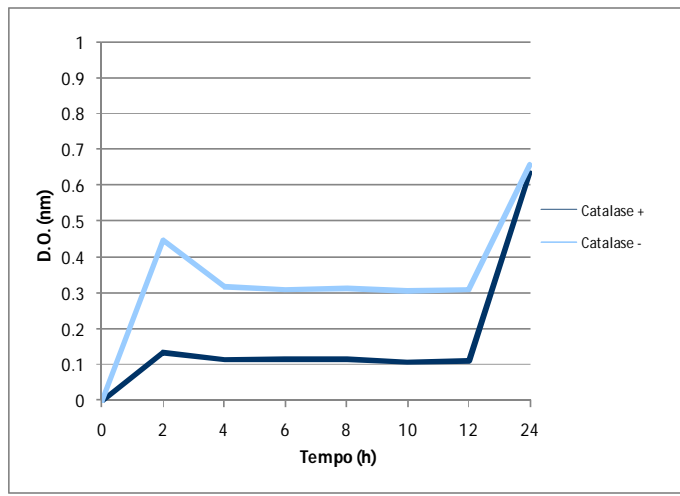

Gráfico 60: Meio de cultura (BHI) + Bactérias a concentração aproximada de $2,63 \times 10^{6} \mathrm{CFU} / \mathrm{mL}^{-1}+7,8125 \times 10^{-13} \mu \mathrm{g}$ de veneno 
Gráficos de 61 a 98- Referente à fração do pico 4: São plotados os resultados da atividade bactericida em função do tempo, na presença ou ausência de catalase na concentração de $2 \mathrm{mg} / \mathrm{mL}$.

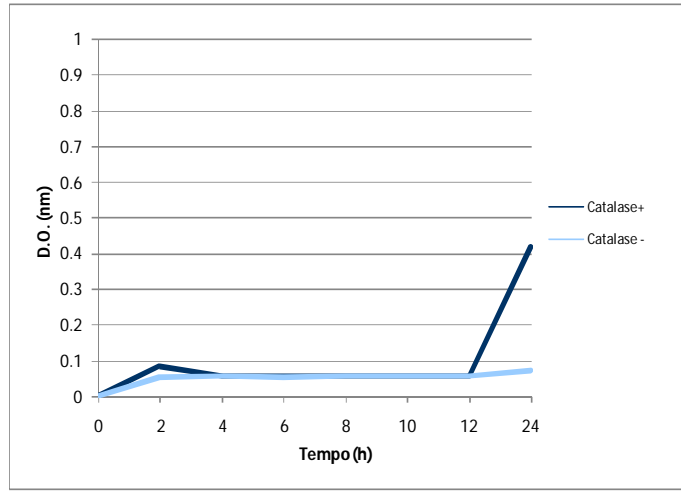

Gráfico 61: Meio de cultura (BHI)

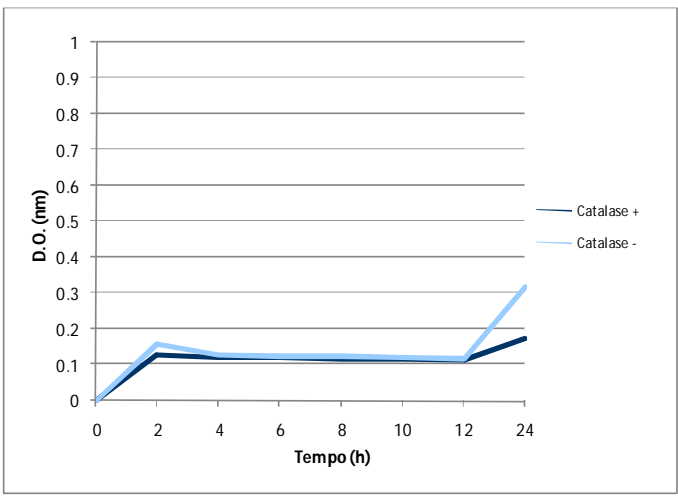

Gráfico 62: Meio de cultura (BHI) + Bactérias a concentração aproximada de $2,63 \times 10^{6} \mathrm{CFU} / \mathrm{mL}^{-1}$

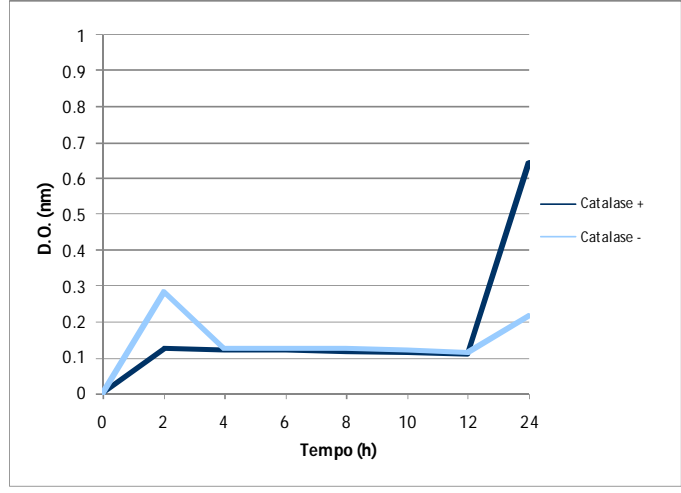

Gráfico 63: Meio de cultura (BHI) + Bactérias a concentração aproximada de $2,63 \times 10^{6} \mathrm{CFU} / \mathrm{mL}^{-1}+4 \times 10^{-2} \mu \mathrm{g}$ de veneno

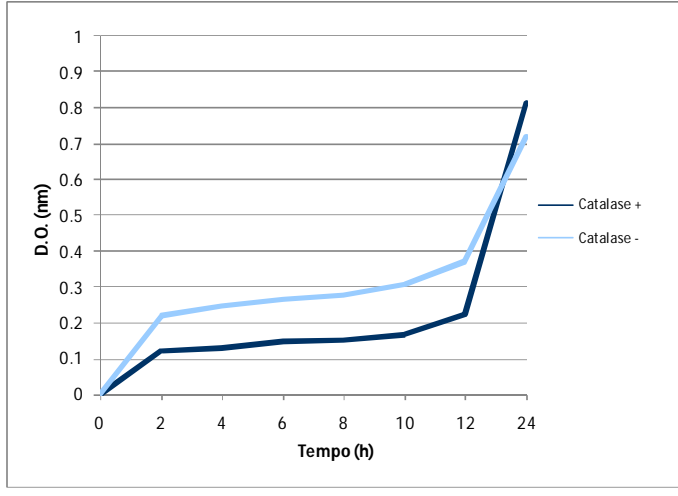

Gráfico 64: Meio de cultura (BHI) + Bactérias a concentração aproximada de $2,63 \times 10^{6} \mathrm{CFU} / \mathrm{mL}^{-1}+2 \times 10^{-2} \mu \mathrm{g}$ de veneno 


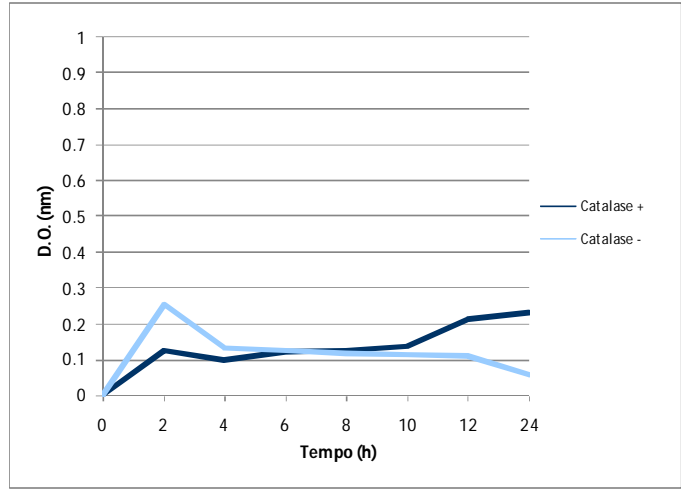

Gráfico 65: Meio de cultura (BHI) + Bactérias a concentração aproximada de $2,63 \times 10^{6} \mathrm{CFU} / \mathrm{mL}^{-1}+1 \times 10^{-2} \mu \mathrm{g}$ de veneno

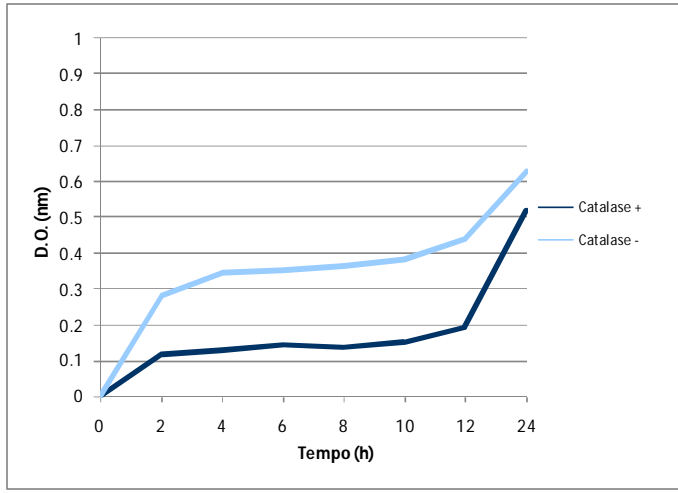

Gráfico 66: Meio de cultura (BHI) + Bactérias a concentração aproximada de $2,63 \times 10^{6} \mathrm{CFU} / \mathrm{mL}^{-1}+5 \times 10^{-3} \mu \mathrm{g}$ de veneno

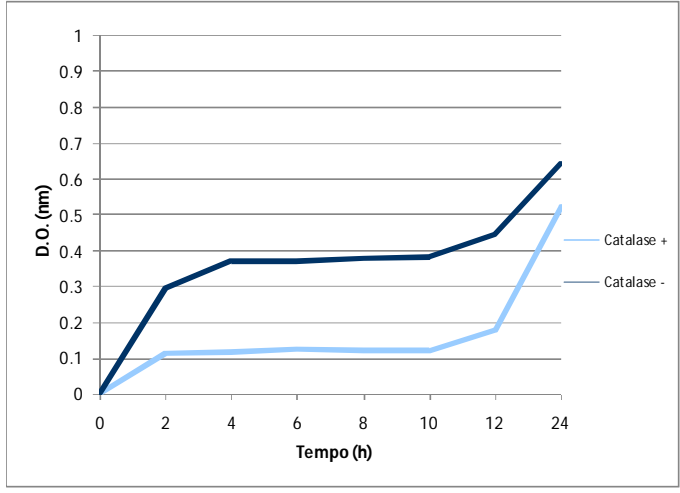

Gráfico 67: Meio de cultura (BHI) + Bactérias a concentração aproximada de $2,63 \times 10^{6} \mathrm{CFU} / \mathrm{mL}^{-1}+2,5 \times 10^{-5} \mu \mathrm{g}$ de veneno

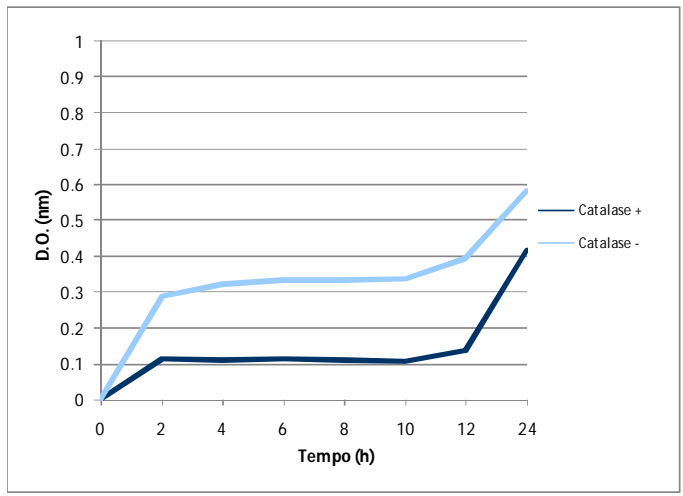

Gráfico 69: Meio de cultura (BHI) + Bactérias a concentração aproximada de $2,63 \times 10^{6} \mathrm{CFU} / \mathrm{mL}^{-1}+6,25 \times 10^{-8} \mu \mathrm{g}$ de veneno

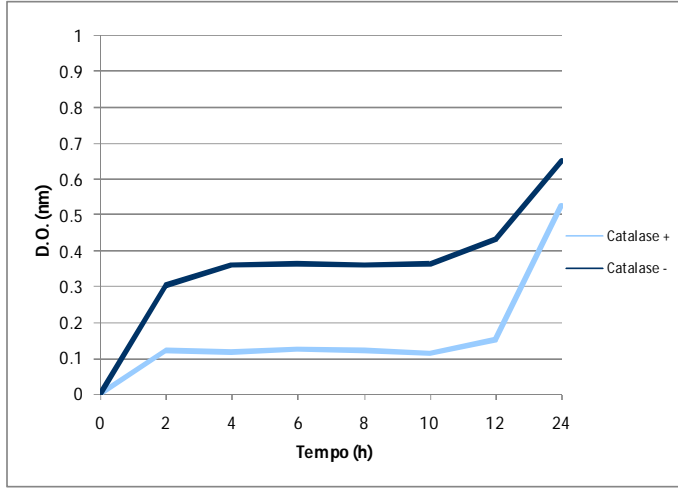

Gráfico 68: Meio de cultura (BHI) + Bactérias a concentração aproximada de $2,63 \times 10^{6} \mathrm{CFU} / \mathrm{mL}^{-1}+1,25 \times 10^{-7} \mu \mathrm{g}$ de veneno

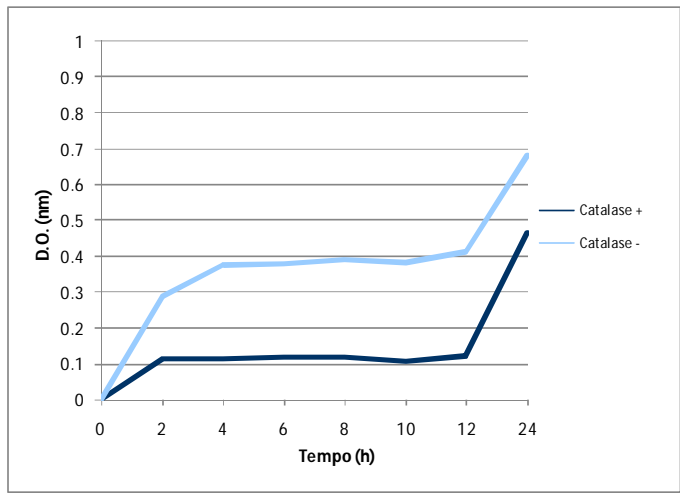

Gráfico 70: Meio de cultura (BHI) + Bactérias a concentração aproximada de $2,63 \times 10^{6} \mathrm{CFU} / \mathrm{mL}^{-1}+3,25 \times 10^{-10} \mu \mathrm{g}$ de veneno 
MOSCA, R.C., 2008

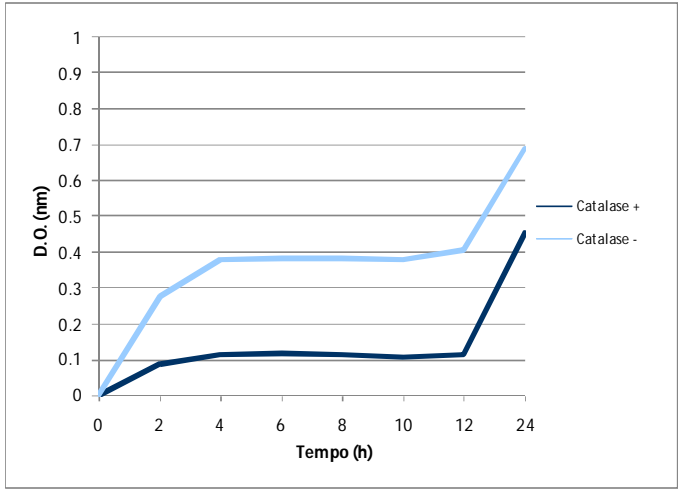

Gráfico 71: Meio de cultura (BHI) + Bactérias a concentração aproximada de $2,63 \times 10^{6} \mathrm{CFU} / \mathrm{mL}^{-1}+1,5625 \times 10^{-12} \mu \mathrm{g}$ de veneno

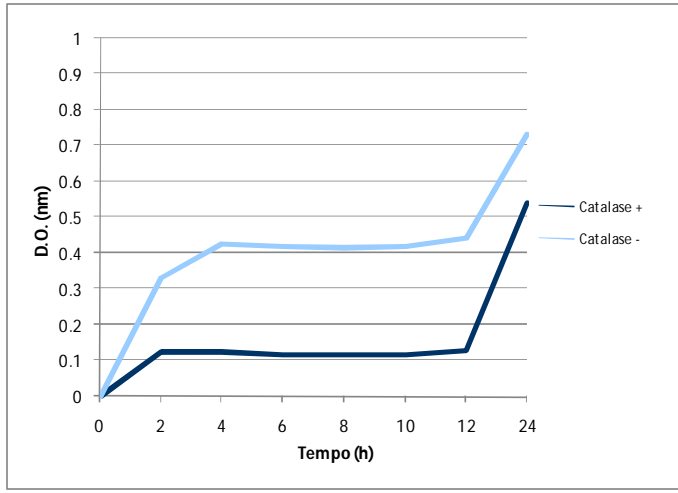

Gráfico 72: Meio de cultura (BHI) + Bactérias a concentração aproximada de $2,63 \times 10^{6} \mathrm{CFU} / \mathrm{mL}^{-1}+7,8125 \times 10^{-13} \mu \mathrm{g}$ de veneno 
Gráficos de 73 a 74 - Referente à fração do pico 5: São plotados os resultados da atividade bactericida em função do tempo, na presença ou ausência de catalase na concentração de $2 \mathrm{mg} / \mathrm{mL}$.

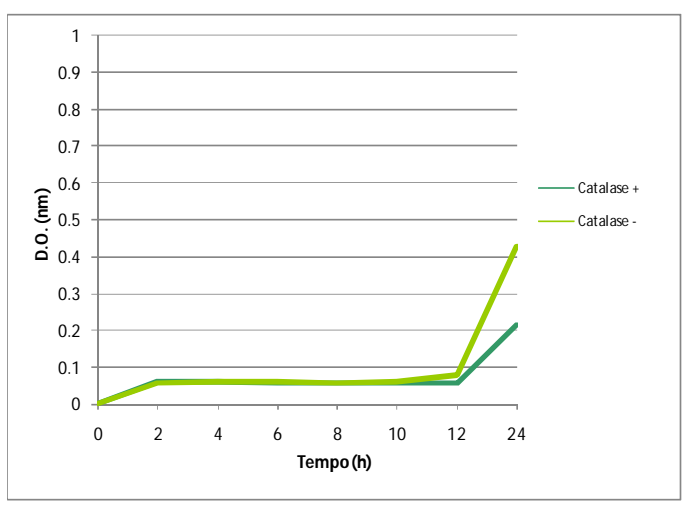

Gráfico 73: Meio de cultura $(\mathrm{BHI})$

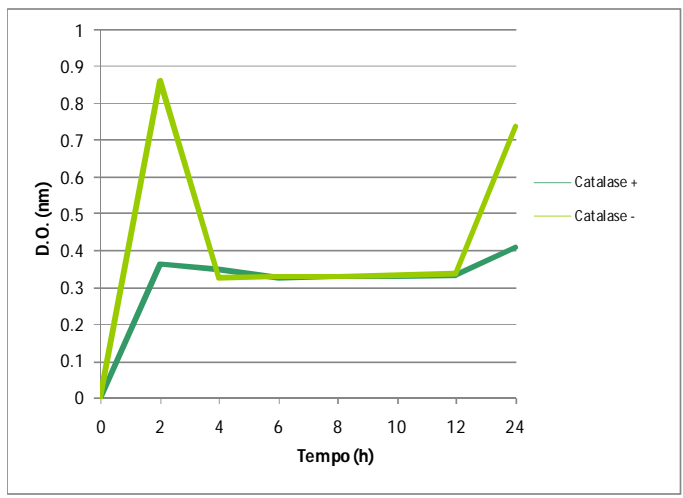

Gráfico 63: Meio de cultura (BHI) + Bactérias a concentração aproximada de $2,63 \times 10^{6} \mathrm{CFU} / \mathrm{mL}^{-1}+4 \times 10^{-2} \mu \mathrm{g}$ de veneno

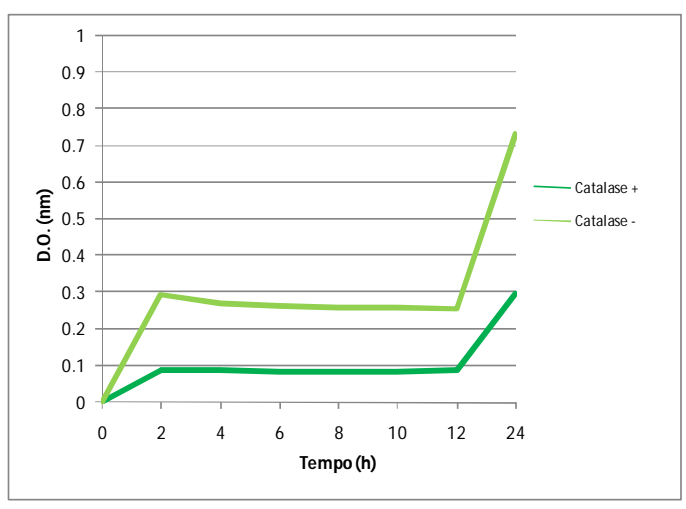

Gráfico 74: Meio de cultura (BHI) + Bactérias a concentração aproximada de $2,63 \times 10^{6} \mathrm{CFU} / \mathrm{mL}^{-1}$

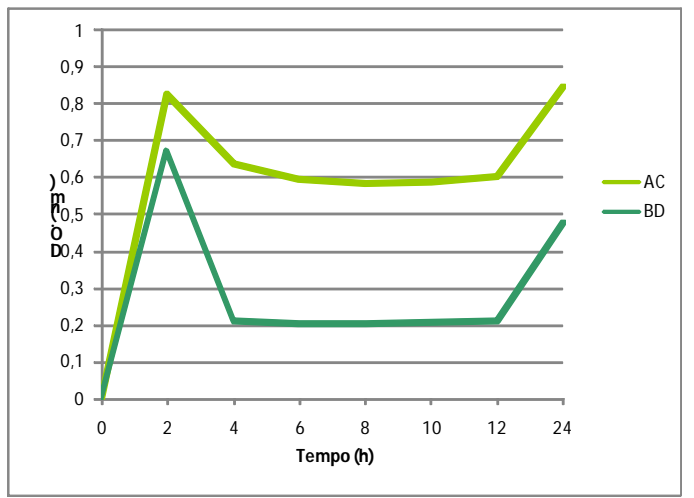

Gráfico 76: Meio de cultura $(\mathrm{BHI})+$ Bactérias a concentração aproximada de $2,63 \times 10^{6} \mathrm{CFU} / \mathrm{mL}^{-1}+2 \times 10^{-2} \mu \mathrm{g}$ de veneno 


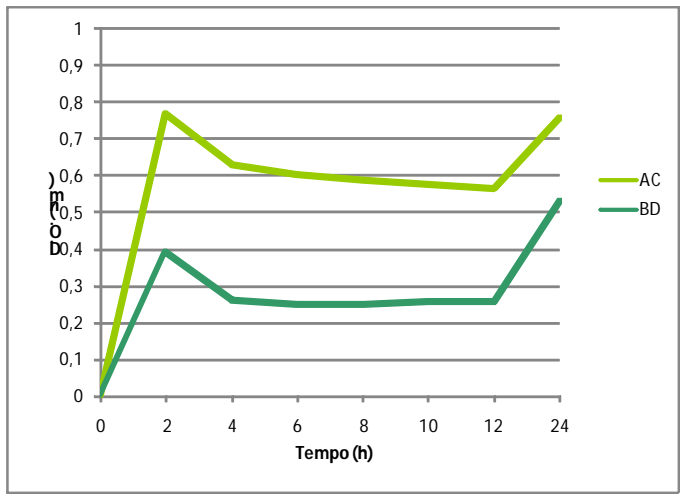

Gráfico 77: Meio de cultura (BHI) + Bactérias a concentração aproximada de $2,63 \times 10^{6} \mathrm{CFU} / \mathrm{mL}^{-1}+1 \times 10^{-2} \mu \mathrm{g}$ de veneno

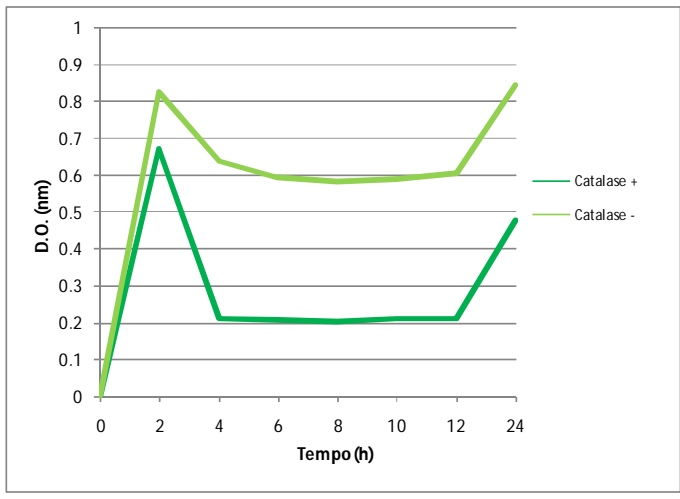

Gráfico 78: Meio de cultura (BHI) + Bactérias a concentração aproximada de $2,63 \times 10^{6} \mathrm{CFU} / \mathrm{mL}^{-1}+5 \times 10^{-3} \mu \mathrm{g}$ de veneno

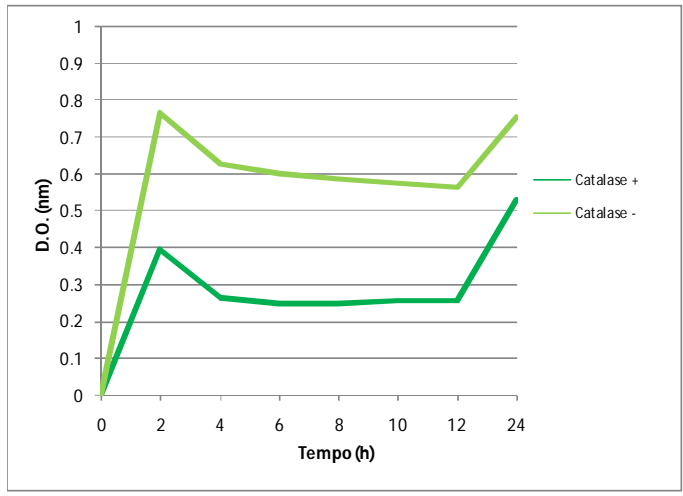

Gráfico 79: Meio de cultura (BHI) + Bactérias a concentração aproximada de $2,63 \times 10^{6} \mathrm{CFU} / \mathrm{mL}^{-1}+2,5 \times 10^{-5} \mu \mathrm{g}$ de veneno

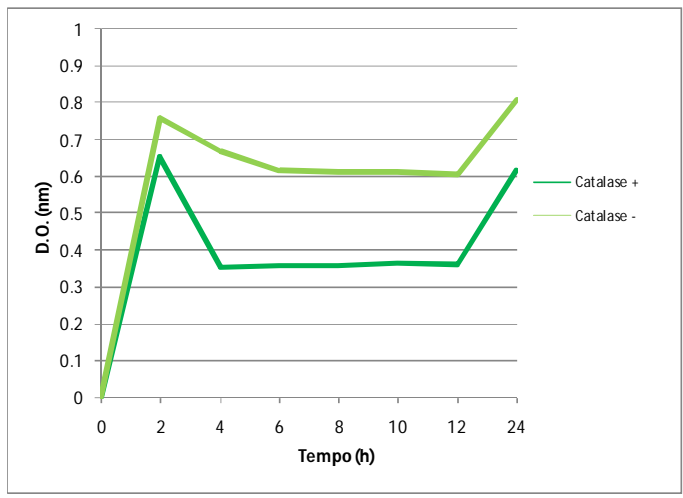

Gráfico 81: Meio de cultura (BHI) + Bactérias a concentração aproximada de $2,63 \times 10^{6} \mathrm{CFU} / \mathrm{mL}^{-1}+6,25 \times 10^{-8} \mu \mathrm{g}$ de veneno

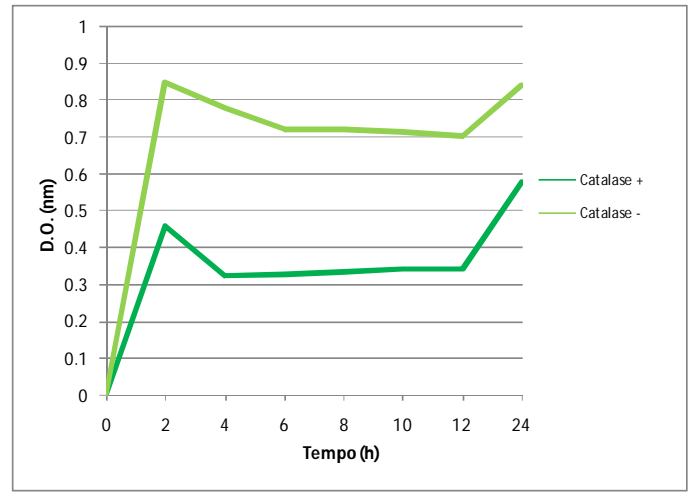

Gráfico 80: Meio de cultura (BHI) + Bactérias a concentração aproximada de $2,63 \times 10^{6} \mathrm{CFU} / \mathrm{mL}^{-1}+1,25 \times 10^{-7} \mu \mathrm{g}$ de veneno

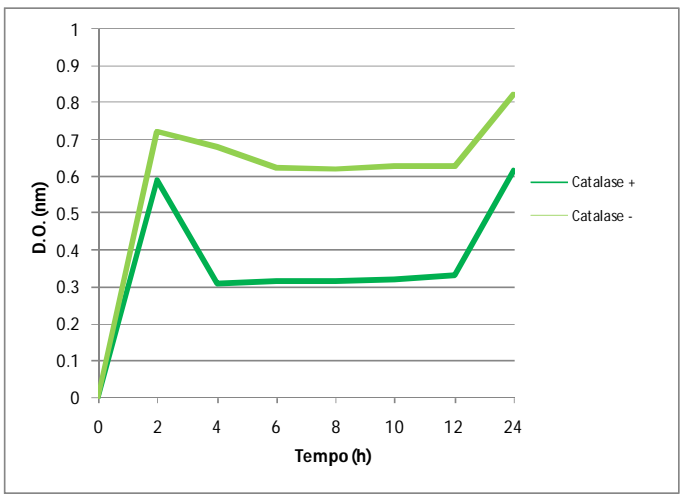

Gráfico 82: Meio de cultura (BHI) + Bactérias a concentração aproximada de $2,63 \times 10^{6} \mathrm{CFU} / \mathrm{mL}^{-1}+3,25 \times 10^{-10} \mu \mathrm{g}$ de veneno 
MOSCA, R.C., 2008

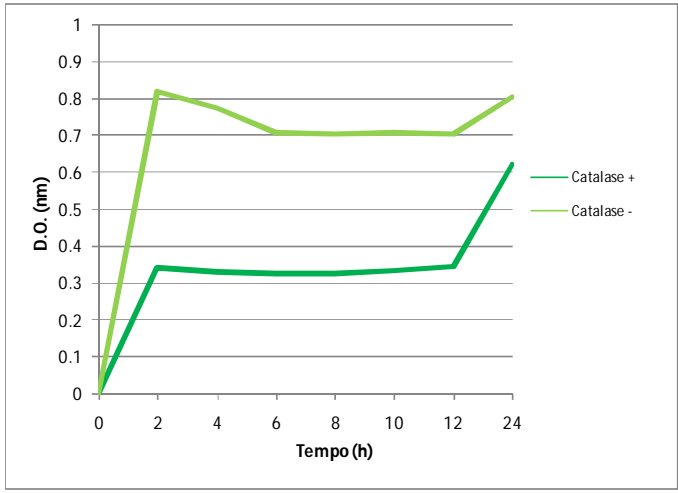

Gráfico 83: Meio de cultura (BHI) + Bactérias a concentração aproximada de $2,63 \times 10^{6} \mathrm{CFU} / \mathrm{mL}^{-1}+1,5625 \times 10^{-12} \mu \mathrm{g}$ de veneno

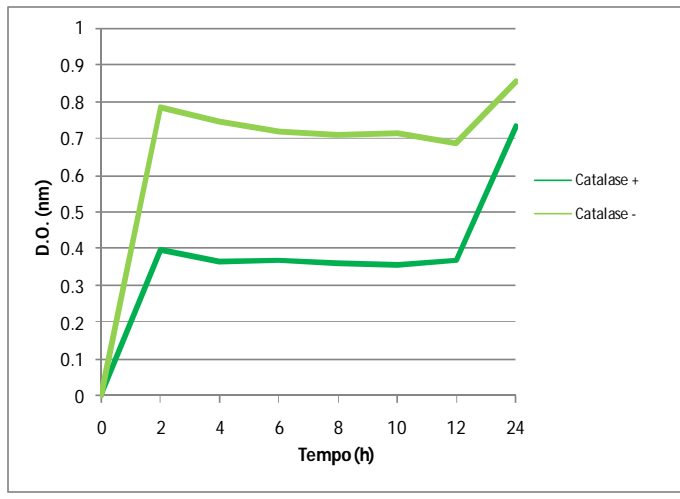

Gráfico 84: Meio de cultura (BHI) + Bactérias a concentração aproximada de $2,63 \times 10^{6} \mathrm{CFU} / \mathrm{mL}^{-1}+7,8125 \times 10^{-13} \mu \mathrm{g}$ de veneno 